INFORMING THE INFORMAL:

VISUALIZING LANEWAY HOUSING AND INCREASED DENSITY IN TORONTO

by

\begin{abstract}
Samira Behrooz
Master of Historic Preservation, Tehran Azad University, 2011

BArch, Tehran Azad University, 2006
\end{abstract}

\begin{abstract}
A Major Research Paper
presented to Ryerson University

in partial fulfillment of the requirements for the degree of

Master of Planning

in

Urban Development
\end{abstract}

Toronto, Ontario, Canada, 2014

(C) Samira Behrooz 2014 


\section{Author's Declaration}

I hereby declare that I am the sole author of this major research paper. This is a true copy of the major research paper, including any required final revisions, as accepted by my examiners.

I authorize Ryerson University to lend this major research paper to other institutions or individuals for the purpose of scholarly research.

I further authorize Ryerson University to reproduce this major research paper by photocopying or by other means, in total or in part, at the request of other institutions or individuals for the purpose of scholarly research.

I understand that my major research paper may be made electronically available to the public. 


\title{
INFORMING THE INFORMAL: \\ VISUALIZING LANEWAY HOUSING AND INCREASED DENSITY IN TORONTO
}

\author{
(C) Samira Behrooz, 2014 \\ Master of Planning \\ in \\ Urban Development \\ Ryerson University
}

\begin{abstract}
Toronto is growing and attracting new population. Given that housing is a basic human need, Toronto's population growth indicates a rising demand for housing. Meanwhile, spatial polarization of income is increasing in the city. Using Hulchanski's illuminating study outlining those low and middle income households initially lived in the core of the city, near to transit networks and currently they cannot due to the high costs of housing this research investigates the physical and spatial capacity of a Toronto neighbourhood to increase affordable housing close to public transit while maintaining the physical character of the neighbourhood. As a means to address this affordable housing crisis laneway and informal housing is studied and the impact of these on the urban fabric, morphology, of neighbourhoods is studied. This research paper utilizes a mixed methods approach using semistructured interviews, field research, spatial analysis and mapping, and the development of scenarios to test laneway and informal housing paradigms. This research concludes that: 1) informal housing and laneway housing can increase density while maintaining the physical character of a neighbourhood, 2) Toronto has an under-utilized laneway system that is a missed opportunity to increase density, 3) The current density limit for stable neighbourhoods defined by Toronto's Zoning By-law is not realistic and there is a potential for increasing density limit while retaining the integrity of neighbourhood character, 4) Four to six storey laneway developments can create a new distinct character in laneways without changing street character.
\end{abstract}

Key words: informal housing, laneway housing, affordability, density, Toronto 


\section{Acknowledgments}

With much gratitude and appreciation to Shelagh McCartney for guiding me along this research. Shelagh I would like to thank you for all your time and support. You pushed me out of my comfort zone and I am very grateful for that. You are very smart and I enjoyed working with you. You helped me to be a better version of myself, it was very stressful at some points but I think it was worth it. I have learnt a lot in this process and especially from your thorough feedbacks.

Thank you to Nina-Marie Lister for accepting to be my second reader and also for all the past two years. Nina-Marie, it was a pleasure to work with you. You are very thoughtful, cheerful and a source of motivation for me. When I did not see my abilities and strengths, you always supported me and encouraged me. Thank you!

Thanks to all my classmates, faculty and staff in the School of Urban and Regional Planning, Ryerson University for providing me such a great opportunity to learn.

Thanks to Brennan, Mark, Mohammad! It was a pleasure to work with you and having your input in my research.

Thank you Joey for all your support and encouragement, you helped me a lot during the past two years and especially in the past four months.

I don't know how my life would have looked like without the love and support from my family. Mom and Dad! Thank you for all time encouragement. Saghar and Sara! Thank you for your wonderful kindness and also patience with me. And Behtash! Thank you for encouraging my creativity and thanks a lot for being there for me. 


\section{Dedication}

To my lovely parents 


\section{Table of Contents:}

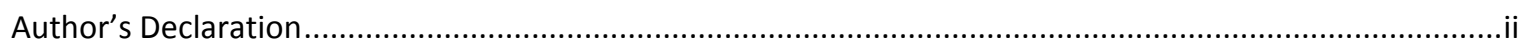

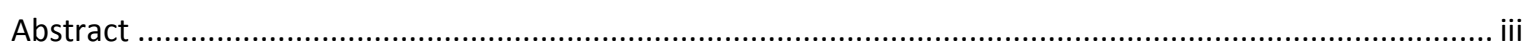

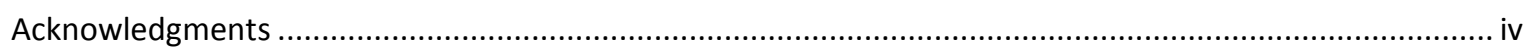

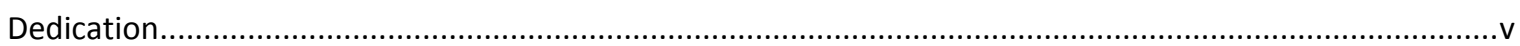

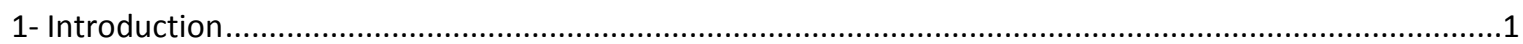

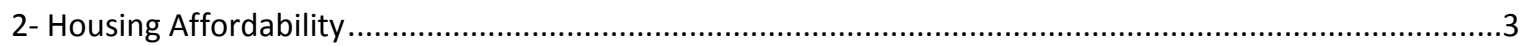

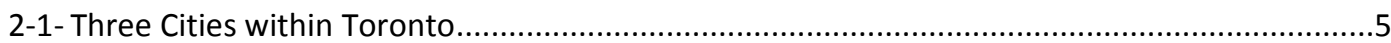

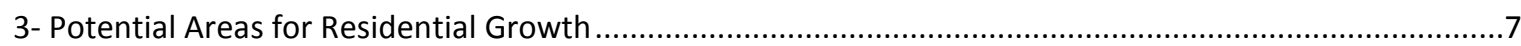

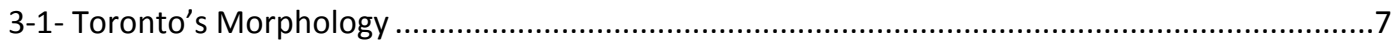

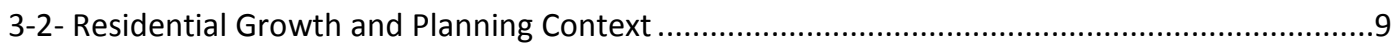

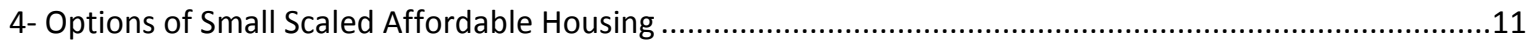

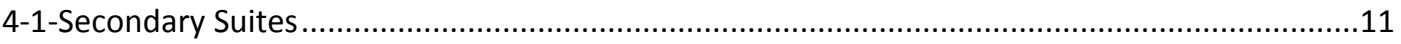

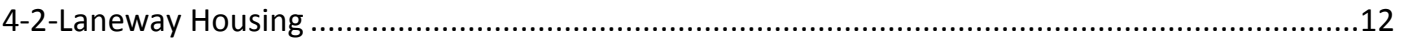

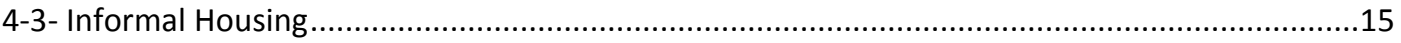

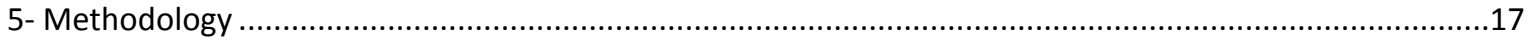

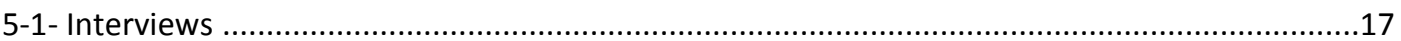

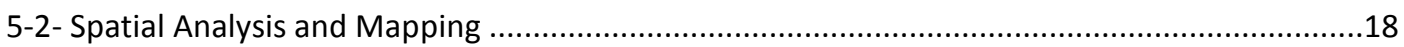

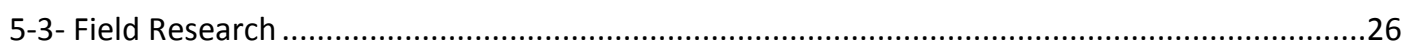

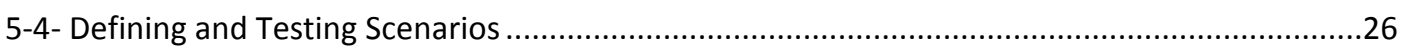

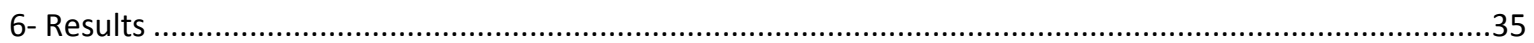

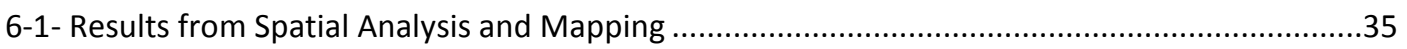

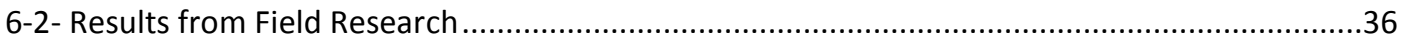

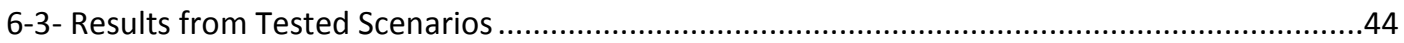

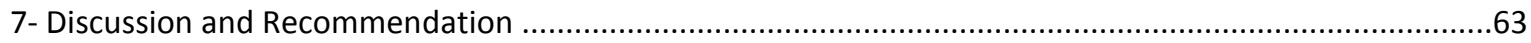

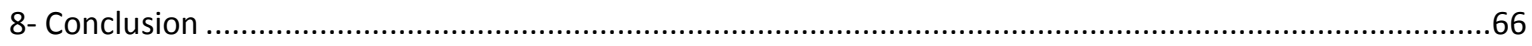




\section{List of Tables:}

Table 1: Estimates of number of affordable apartment rental units in Toronto (Tyndorf, 2006)...................................4

Table 2: Summary of the developed scenarios for increasing density while maintaining neighbourhood character .......28

Table 3: Summary of the noticed informality in the test area, Euclid Avenue, east side............................................37

Table 4: Summary of the noticed informality in the test area, Palmerston Boulevard, west side....................................38

Table 5: Summary of the noticed informality in the test area, Palmerston Boulevard, east side....................................39

Table 6: Summary of the noticed informality in the test area, Markham Street, west side ........................................40

Table 7: Summary of the noticed informality in the test area, Markham Street, east side ............................................41

Table 8: Summary of the noticed informality in the test area, Bathurst Street, west side..........................................42

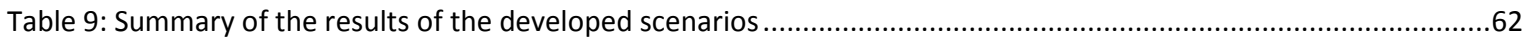




\section{List of Figures:}

Figure 1: Percent of households with affordability problems

by tenure and income category, Toronto 2001 (Tyndorf, 2006)

Figure 2: Percent of households with affordability problems

by tenure and household type, Toronto 2001 (Tyndorf, 2006)

Figure 3: Change in average individual income, City of Toronto, 1970 - 2005 (Hulchanski, 2010) ................................5

Figure 4: Average individual income, City of Toronto, 1970 (Hulchanski, 2010) .........................................................5

Figure 5: Average individual income, City of Toronto, 2005 (Hulchanski, 2010) ...........................................................5

Figure 6: The Urban Structure map (City of Toronto Official Plan, 2010) …............................................................

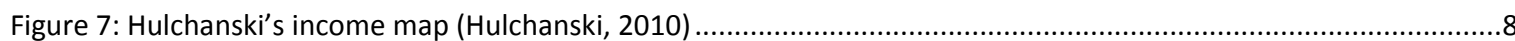

Figure 8: Plan of the harbour of Toronto with the proposed town and settlement, 1788 (Toronto Public Library, 2014) 9

Figure 9: Incremental subdivision of a typical Toronto block into smaller lots (Shim, Chong and others, 2004)............12

Figure 10: 7 Leslie Garden Lane Shim - Sutcliffe Architects, 1993 (Stinson and Van 2003) ..........................................13

Figure 11: 1 Ways Lane A.J. Diamond \& Donald Schmitt \& Company Architects, early 2001 (City of Toronto website)...13

Figure 12: City \# 2 and City \# 3 in 1970 (Hulchanski, 2010, edited by author, 2014) ..................................................19

Figure 13: City \# 2 and City \# 3 in 2005 (Hulchanski, 2010, edited by author, 2014) ..................................................19

Figure 14: City \# 2 and City \# 3 in 1970 and 2005 (Hulchanski, 2010, edited by author, 2014) ....................................19

Figure 15: Walkable areas of Toronto (City of Toronto, 2012, edited by author, 2014) ............................................20

Figure 16: Walkable areas in City\#2 and City \#3 of Toronto

(City of Toronto, 2012 and Hulchanski, 2010, edited by author, 2014) ....................................................21

Figure 17: The GIS map laid on top of the Walkable areas in City\#2 and City \#3

(City of Toronto, 2012 and Hulchanski, 2010, Ryserson University, edited by author, 2014).......................21

Figure 18: Potential study areas for testing scenarios (Ryserson University, edited by author, 2014) ..........................22

Figure 19: Potential test site 1 in Palmerston neighbourhood in Toronto (Image by author, 2014)

Original map from: Ryerson University, 2014

Figure 20: Potential test site 3 in Trinity Bellwood neighbourhood in Toronto (Image by author, 2014)

Original map from: Ryerson University, 2014

Figure 21: Potential test site 2 in Parkdale neighbourhood in Toronto (Image by author, 2014)

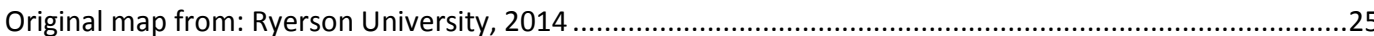

Figure 22: Schematic section illustrating pedestrian visual zone from street (Image by author, 2014)

Figure 23: Schematic map illustrating the middle and low income areas under the threat of complete gentrification

(Hulchanski, 2010, edited by author, 2014)

Figure 24: Schematic map illustrating the middle and low income areas near to laneway structure and under the threat of complete gentrification (City of Toronto, 2012 and Hulchanski, 2010, edited by author, 2014) ................36

Figure 25: Field research map, Euclid Avenue (Ryerson University, edited by author, 2014) .........................................37

Figure 26: Field research map, Palmerston Boulevard, west side (Ryerson University, edited by author, 2014)..............38

Figure 27: Field research map, Palmerston Boulevard, east side (Ryerson University, edited by author, 2014) ..............39

Figure 28: Field research map, Markham Street, west side (Ryerson University, edited by author, 2014) .....................40 
Figure 29: Field research map, Markham Street, east side (Ryerson University, edited by author, 2014)

Figure 30: Field research map, Bathurst Street, west side (Ryerson University, edited by author, 2014).....

Figure 31, 32, 33, 34, 35 and 36: The street character of the study area in Palmerston in Toronto

(Images by author, 2014)

Figure 37, 38, 39, 40, 41 and 42: The laneway character of the study area

in Palmerston in Toronto (Images by author, 2014)

Figure 43: Plan diagram for Scenario A-1 presenting the number of dwelling units on each property in the test area in Palmerston in Toronto (Images by author, 2014)

Figure 44: 3D model of Scenario A-1 depicting the Existing built form in the test area in

Palmerston in Toronto (Images by author, 2014)

Figure 45: Detroit, MI with similar density as Scenario A-1 (Campoli and MacLean, 2007)

Figure 46: Plan diagram for Scenario A-2 presenting the number of dwelling units on each property in the test area in

Palmerston in Toronto (Images by author, 2014)

Figure 47: 3D model of Scenario A-2 depicting the Existing built form in the test area in

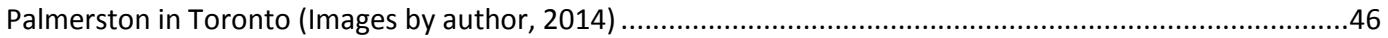

Figure 48: Washington, DC with similar density as Scenario A-2 (Campoli and MacLean, 2007)

Figure 49 and 50: Schematic section illustrating the pedestrian visual zone from street and the built form in

Scenario A-2 (Images by author, 2014)

Figure 51: Plan diagram for Scenario A-3 presenting the number of legal dwelling units on each property in the test

area in Palmerston in Toronto (Images by author, 2014)

Figure 52: 3D model of Scenario A-3 depicting the Existing as-of-right in the test area in

Palmerston in Toronto (Images by author, 2014)

Figure 53: 3D model of Scenario A-3 laid on top of the existing built form as-of-right in the test area in

Palmerston in Toronto (Images by author, 2014).

Figure 54: Plan diagram for Scenario B -1 presenting the number of dwelling units on each property in the test area in

Palmerston in Toronto (Images by author, 2014)

Figure 55: 3D model of Scenario B-1 depicting the Addition of suites located above garages in the test area in

Palmerston in Toronto (Images by author, 2014)

Figure 56: 3D model of existing as-of-right laid on top of the built form in Scenario B-1 in the test area in

Palmerston in Toronto (Images by author, 2014)

Figure 57 and 58: Schematic section illustrating the pedestrian visual zone from street and the built form in

Scenario B-1 (Images by author, 2014)

Figure 59: Plan diagram for Scenario B -2 presenting the number of dwelling units on each property in the test area in

Palmerston in Toronto (Images by author, 2014)

Figure 60: 3D model of Scenario B-2 depicting the Addition of suites located above garages in the test area in

Palmerston in Toronto (Images by author, 2014)

Figure 61: 3D model of existing as-of-right laid on top of the built form in Scenario B-2 in the test area in

Palmerston in Toronto (Images by author, 2014) . .50 
Figure 62: Boulder, CO with similar density as Scenario B-2 (Campoli and MacLean, 2007).....

Figure 63 and 64: Schematic section illustrating the pedestrian visual zone from street and the built form in

Scenario B-2 (Images by author, 2014)

Figure 65: Plan diagram for Scenario C -1-1 presenting the number of dwelling units on each property in the test area in Palmerston in Toronto (Images by author, 2014)

Figure 66: 3D model of Scenario C-1-1 depicting the addition of one storey laneway houses in the test area in

Palmerston in Toronto (Images by author, 2014)

Figure 67: Portland, OR with similar density as Scenario B-2 (Campoli and MacLean, 2007).

Figure 68: 3D model of existing as-of-right laid on top of the built form in Scenario C-1-1 in the test area in

Palmerston in Toronto (Images by author, 2014) .

Figure 69 and 70: Schematic section illustrating the pedestrian visual zone from street and the built form in

Scenario C-1 (Images by author, 2014) .

Figure 71: 3D model of Scenario C-1-2 depicting the addition of one storey laneway houses in the test area in

Palmerston in Toronto (Images by author, 2014)

Figure 72: 3D model of existing as-of-right laid on top of the built form in Scenario C-1-2 in the test area in

Palmerston in Toronto (Images by author, 2014) . .53

Figure 73: Boston, MI with similar density as Scenario B-2 (Campoli and MacLean, 2007).

Figure 74: Plan diagram for Scenario C -2 presenting the number of dwelling units on each property in the test area in

Palmerston in Toronto (Images by author, 2014).

Figure 75: 3D model of Scenario C-2-1 depicting the addition of one and half storey laneway houses in the test area in

Palmerston in Toronto (Images by author, 2014)

Figure 76: 3D model of existing as-of-right laid on top of the built form in Scenario C-2-1 in the test area in

Palmerston in Toronto (Images by author, 2014)

Figure 77: Schematic section \#1 illustrating the pedestrian visual zone from street and the built form in

Scenario C-2 (Images by author, 2014)

Figure 78: 3D model of Scenario C-2-2 depicting the addition of one and half storey laneway houses in the test area in

Palmerston in Toronto (Images by author, 2014).

Figure 79: 3D model of existing as-of-right laid on top of the built form in Scenario C-2-2 in the test area in

Palmerston in Toronto (Images by author, 2014)

Figure 80: Schematic section \#2 illustrating the pedestrian visual zone from street and the built form in

Scenario C-2 (Images by author, 2014)

Figure 81: Plan diagram for Scenario C -3 presenting the number of dwelling units produced by each laneway house in the test area in Palmerston in Toronto (Images by author, 2014)

Figure 82: Plan diagram for Scenario C -3 presenting the number of dwelling units on each property in the test area in Palmerston in Toronto (Images by author, 2014)

Figure 83: 3D model of Scenario C-3 depicting the addition of three storey laneway houses in the test area in

Palmerston in Toronto (Images by author, 2014)

Figure 84: 3D model of existing as-of-right laid on top of the built form in Scenario C-3 in the test area in 
Palmerston in Toronto (Images by author, 2014)

Figure 85: Oakland, CA with similar density as Scenario B-2 (Campoli and MacLean, 2007).

Figure 86 and 87: Schematic section illustrating the pedestrian visual zone from street and the built form in Scenario C-3 (Images by author, 2014)

Figure 88: Plan diagram for Scenario D presenting the number of dwelling units produced by each

laneway house, ground floor, in the test area in Palmerston in Toronto (Images by author, 2014)

Figure 89: Plan diagram for Scenario D presenting the number of dwelling units produced by each laneway house, upper floors, in the test area in Palmerston in Toronto (Images by author, 2014) ......................................58

Figure 90: 3D model of Scenario D depicting the addition of multi storey laneway houses in the test area in

Palmerston in Toronto (Images by author, 2014) .

Figure 91: 3D model of existing as-of-right laid on top of the built form in Scenario D-1 in the test area in

Palmerston in Toronto (Images by author, 2014)

Figure 92 and 93: Schematic section illustrating the pedestrian visual zone from street and the built form in

Scenario D-1 (Images by author, 2014).

Figure 94: 3D model of Scenario D -2 depicting the addition of multi storey laneway houses in the test area in

Palmerston in Toronto (Images by author, 2014)

Figure 95: 3D model of existing as-of-right laid on top of the built form in Scenario D-2 in the test area in

Palmerston in Toronto (Images by author, 2014)

Figure 96 and 97: Schematic section illustrating the pedestrian visual zone from street and the built form in

Scenario D-2 (Images by author, 2014).....

Figure 98: A suite located above a garage, noticed informality in the study area (Image by author, 2014) .64

Figure 99: Multiple mail boxes and ring bells, noticed informality in the study area (Image by author, 2014) .64

Figure 100 and 101: Via dei Coronari (left) and Via Giulia (right) in Rome, Italy illustrating two great streets with a similar proportion of width and height to scenario D. (Images retrieved from: http://www.panoramio.com/ and www.go-today.com/blog/travel-explorations/8-unforgettable-experiences-in-rome-italy/... .66 


\section{List of Appendices:}

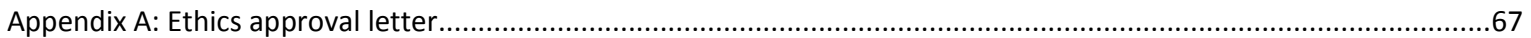

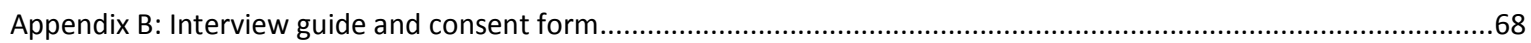

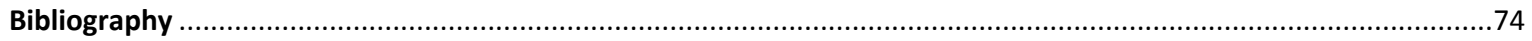




\section{1- Introduction}

Toronto, the most populous Canadian city, continues to grow and attract residents. Toronto's population has increased 4.5\% from 2006 to 2011 (Statistics Canada, 2011) and the population of 3.4 million is anticipated for 2041 (Growth Plan, 2013). The physical city has become polarized between low and high income areas while middle income areas are shrinking. Housing is a fundamental human need, providing housing choice for the growing population is necessary. This study investigates opportunities for increasing density in stable neighbourhoods while maintaining the character of the neighbourhoods that are so important to Toronto and are currently under siege by multi storey development that is radically changing neighbourhood character and providing a singular housing type. This paper studies the potential of laneway housing and informal housing for increasing affordable density and their impact on the morphology of a neighbourhood. Laneway housing is a detached form of infill housing which is secondary to a principal house and typically oriented towards a lane. Informal housing is a dwelling unit that does not comply with urban regulations. Using a set of qualitative methods including interviews, field research and design, this research examines various scenarios with different built form for increasing the number of dwelling units within the existing character of a neighbourhood.

Spatial polarization between high and low income areas in Toronto is increasing and living in the central parts of the city, the inner city, has become less affordable for the middle and income earners due to the high cost of housing in these areas (Hulchanski, 2010). Low and middle income households that initially lived in the core of the city near to transit networks are being pushed out to the edges of the city. In order to slow or stop this trend of gentrification, David Hulchanski (2010) suggests in his report The Three Cities within Toronto, to promote mixed income neighbourhoods and provide affordable housing. Increasing housing affordability in areas in proximity to transit can allow low and middle income households to live in these well serviced areas. Small household size including one person and lone parents have the most affordability problem in Toronto (Tyndorf, 2006), indicating that small sized affordable units are in high demand. Providing small housing choice can increase affordability for small size households and allow them to live in areas well served by transit. A large portion of the walkable areas of Toronto are located in stable neighbourhoods with distinct physical character. While areas near to transit are transforming to high income neighbourhoods, housing choices in these areas become more limited and less affordable. However a closer look at stable neighbourhoods in proximity to transit networks can identify elements that suggest some buildings accommodate more residents than the number they originally designed for. It can be argued that the existence of those dwelling units which do not comply with urban regulations, defined as informal housing, is an existing and further emerging phenomenon to leverage affordability in established neighbourhoods.

Given the value of increasing density in the walkable areas of Toronto, this paper explores opportunities for incremental intensification using the current urban fabrics and land division. Historically incremental growth in Toronto has enabled the city to maintain neighbourhood character while accommodating new density (Baird and Myers, 1978). 
Morphology is defined the study of the physical and spatial characteristics of city fabric and aims to explain transformation process in urban fabric. This research paper investigates the following questions: What are the opportunities for increasing density in established neighbourhoods while maintaining their physical character? How does informal housing contribute to increasing housing affordability? And, how does the practices of informality influence the morphology of a neighbourhood?

This study used semi-structured interviews and relevant literature review to examine housing choice, affordability and informal housing in Toronto. Using information on affordability and physical characteristics of stable neighbourhoods in Toronto and a mapping process the case study area of the Palmerston neighbourhood in Toronto is used to examine various scenarios for increasing density in keeping with the character of the neighbourhood. Field research is conducted in the study area to identify informal housing units. The number of extra units within houses is estimated, suggesting a demand for increasing density. This paper refers to density as the number of dwelling units per hectare rather than the ratio of building area to property area. After identifying the practices of informality in the study area, various scenarios of different logics and levels of intervention for accommodating additional density are defined and tested. These scenarios include the addition of laneway houses and suites above garage to the selected area.

This is an exploratory research paper examining possibilities for increasing density in Toronto through informal housing and laneway housing. It is recognized that there are issues associated with infill intensification such as NIMBYism (Not In My Back Yard) and infrastructure capacity, but this study is limited to the morphological aspect by focusing on the physical and spatial capacity of Toronto urban fabric while retaining neighbourhood character.

This study can contribute to the body of knowledge about informal housing in Toronto and to discussions of possibilities for infill intensification within downtown neighbourhoods, particularly those with established laneway structures. It can also contribute to the debates about leveraging affordable housing by individual home owners and providing housing options for lower and middle income earners.

This paper is organized in the following manner: The first section illustrates the current trends of housing needs and affordability in Toronto. The second section outlines the direction of residential growth in Toronto from planning and morphological perspective. Followed by the third section that presents various alternatives for small scale infill intensification, the methodology of the research is reviewed in the fourth section. In section five the results from various research methods are demonstrated and in section six the research findings are discussed. 


\section{2- Housing Need and Affordability}

Toronto is growing and attracting new population. The 2011 population of the City of Toronto was 2,615,060, with an increase of 4.5\% since 2006 (Statistics Canada, 2011). Given that housing is a basic human need, Toronto's population growth indicates a rising demand for housing. Meanwhile, spatial polarization of income is increasing in the city. Although low and middle income households initially lived in the core of the city, now they cannot afford to live in the core areas due to the high costs of housing in these areas. Higher income households tend to live in the core of the city close to services while lower income individuals have pushed by housing prices out from the core area to the edges of the city, far from services and public transit networks (Hulchanski, 2010).

In the section below current trends of housing needs, affordability and income polarization in the city of Toronto will be outlined.

The Growth Plan for the Greater Golden Horseshoe, enforced in June 2006, manages growth and development throughout the Greater Golden Horseshoe. The Greater Golden Horseshoe is a region that stretches around Lake Ontario from Niagara Falls to Peterborough, with Toronto at its centre. The Growth Plan, as amended in 2013, forecasts for 3.4 million people in the City of Toronto by 2041 with an average growth of 2,600 per year after 2011 (Growth Plan, 2013). To accommodate this population growth an additional 294,480 housing units are required (Housing Potential Analysis, 2011).

Adequate, safe and affordable housing is a fundamental human need (Official Plan, 2006). For the purpose of this study, housing is defined as affordable "if the price of housing does not cost too much in relation to household ability's to pay" (Tyndorf, 2006) and if housing costs allow households to live and stay in areas near to services and transit networks. Alejandro Aravena (2012) in the book "Elemental: Incremental Housing and Participatory Design Manual" argues that reducing the size of dwelling units along with displacing low and middle income households to areas with low land cost are two strategies to make housing more affordable and accessible (Aravena, 2012). This paper focuses on increasing affordability by reducing the size of units, in order to avoid displacement of low and middle income individuals from the core of the city.

Housing affordability can be affected by vacancy rate, purchase and rental rates and the ratio of income to shelter cost. According to the Canada Mortgage and Housing Corporation (CMHC), a household faces affordability challenge if spends more than $30 \%$ of its pre-tax income on securing housing (Tyndorf, 2006). One third of all Toronto households spent more than 30\% of their income on shelter in 2001 and $65 \%$ of those with affordability problems were renters (Tyndorf, 2006). Vacancy rate in Toronto rental market was $1.7 \%$ in 2013 which is below the average national rate of $2.8 \%$, indicating a demand for additional rental units (CMHC, 2013). Every three in ten of low to moderate income households have an affordability problem in Toronto (Tyndorf, 2006). Toronto is also experiencing a shift in the number of single and small family households. Household size can impact housing affordability. Households with less income earners are more likely to face affordability problems. Also the size of households can influence the types of housing that need to be built. Lone parents and single person households 
together account for $60 \%$ of all affordability problems in the City of Toronto (Tyndorf, 2006). Only 6.8\% of bachelor units in Toronto are identified affordable in the year of 2005 (Tyndorf, 2006).

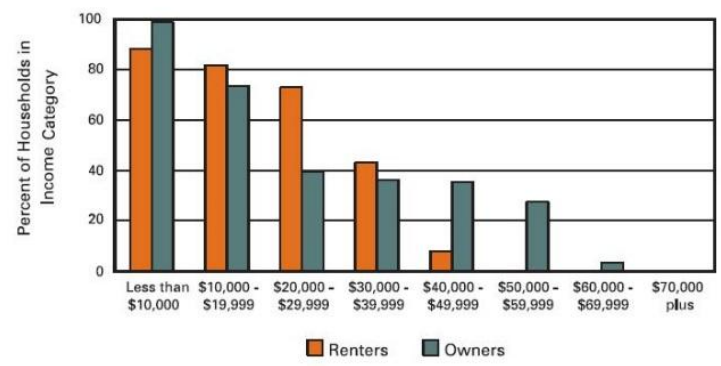

Figure 1: Percent of households with affordability problems by tenure and income category, Toronto 2001 (Tyndorf, 2006)

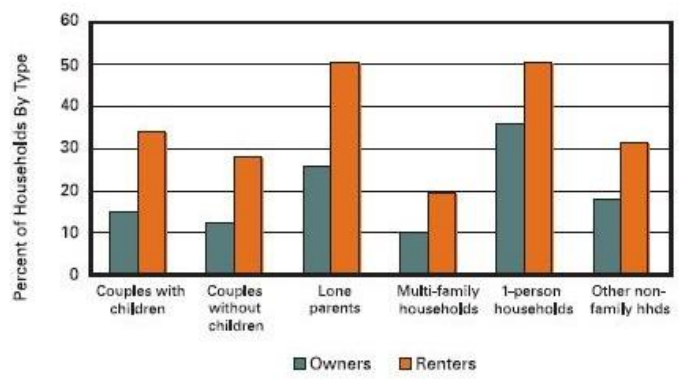

Figure 2: Percent of households with affordability problems by tenure and household type, Toronto 2001 (Tyndorf, 2006)

\begin{tabular}{|c|c|c|c|}
\hline Affordable Threshold - Official Plan Definition & $\begin{array}{r}\text { Affordable } \\
\text { Threshold }\end{array}$ & $\begin{array}{r}\text { Number of } \\
\text { Units }\end{array}$ & $\begin{array}{r}\text { Percent of } \\
\text { Affordable Units }\end{array}$ \\
\hline$\underline{\text { Rental Units }}$ & (\$) & & \\
\hline \multicolumn{4}{|l|}{ Average rent by unit type, 2001} \\
\hline Bachelor & 685 & 11,480 & 8.1 \\
\hline 1-bedroom & 833 & 58,850 & 41.3 \\
\hline 2-bedroom & 984 & 58,439 & 41.0 \\
\hline 3-bedroom & 1,186 & 13,614 & 9.6 \\
\hline Total & & 142,382 & 100.0 \\
\hline \multicolumn{4}{|l|}{ Average rent by unit type, 2005} \\
\hline Bachelor & 726 & 10,231 & 6.8 \\
\hline 1-bedroom & 889 & 62,032 & 41.1 \\
\hline 2-bedroom & 1,060 & 64,556 & 42.9 \\
\hline 3-bedroom & 1,265 & 13,915 & 9.2 \\
\hline Total & & 150,734 & 100.0 \\
\hline
\end{tabular}

Table 1: Estimates of number of affordable apartment rental units in Toronto (Tyndorf, 2006)

This section has demonstrated who faces affordability problem in Toronto and how housing affordability is related to market conditions and housing supply. As lone parents and single individual households face major affordability problems, providing affordable housing for these small size households is essential. Also the lack of small affordable units highlights a serious need for small affordable housing units in Toronto. Therefore this paper focuses on increasing density through the addition of small dwelling units in neighbourhoods hosting low and middle income households. Low and middle income households should be able to live in Toronto to create a sustainable and inclusive city. The next section aims to develop an understanding on where low and income earners live in Toronto. 


\section{2-1- Three Cities within Toronto}

David Hulchanski's research, "The Three Cities within Toronto", highlights the trends of change in household income levels in Toronto's neighbourhoods. He has studied the change in census tract average individual income as a percentage of the Toronto CMA average from 1970 to 2005. Through this research he has introduced the concept of the three cities within Toronto; city of high income (City\#1), of middle income (City\#2) and of low income (City\#3) (Hulchanski, 2010).

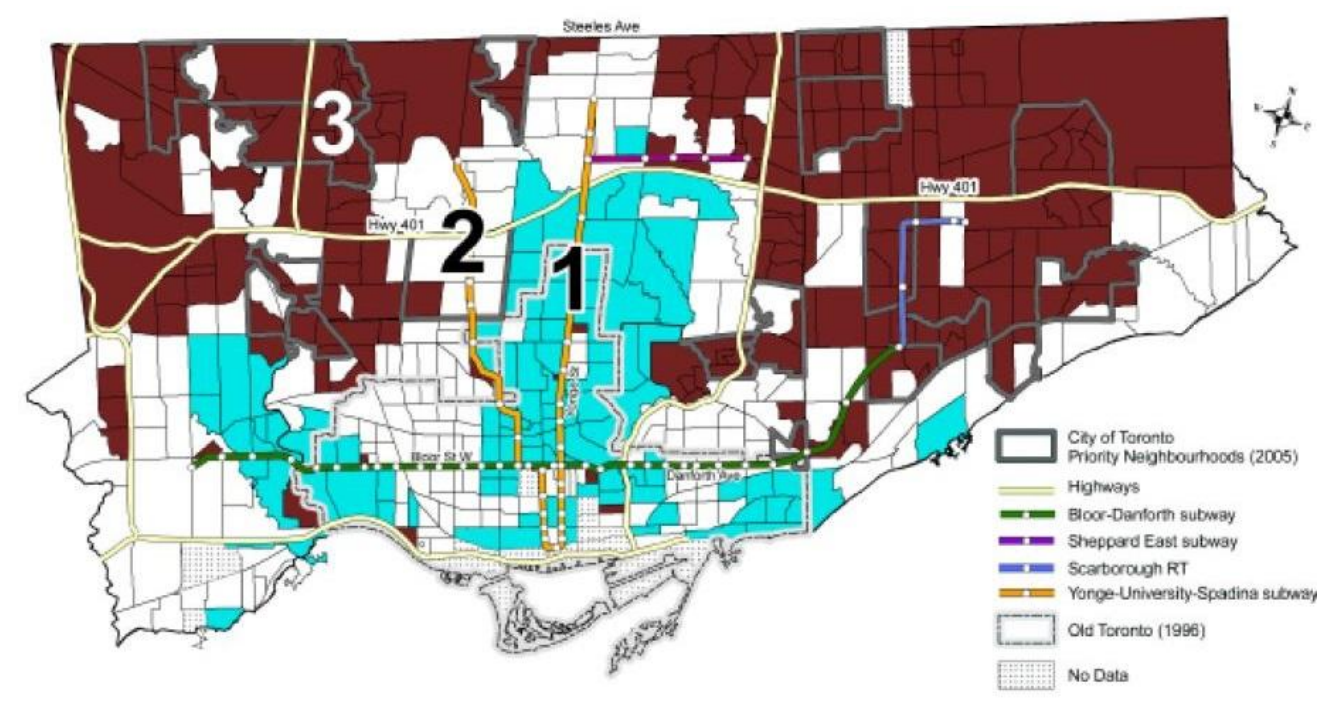

Change in the Census Tract Average Individual Income as a Percentage of the Toronto CMA Average, 1970-2005

\begin{tabular}{lll}
\multicolumn{1}{c}{ City \#1 } & \multicolumn{1}{c}{ City \#2 } & \multicolumn{1}{c}{ City \#3 } \\
Increase of 20\% or More & Increase or Decrease & Decrease of 20\% or More \\
100 Census Tracts, 20\% of City & is Less than 20\% & 206 Census Tracts, 40\% of City \\
208 Census Tracts, 40\% of City &
\end{tabular}

Figure 3: Change in average individual income, City of Toronto, 1970 - 2005 (Hulchanski, 2010)

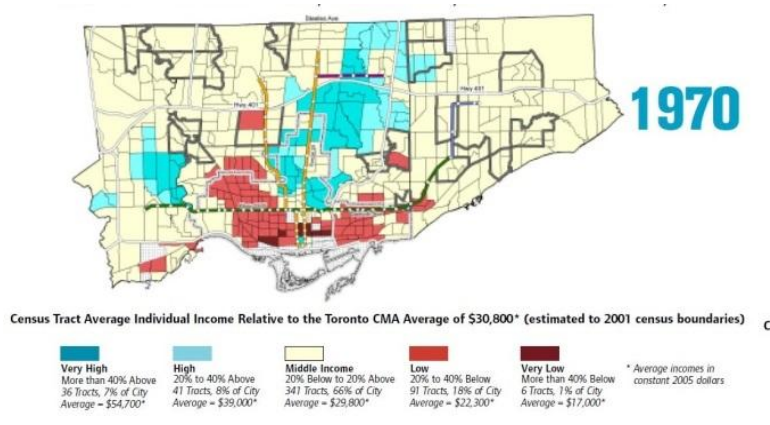

Figure 4: Average individual income, City of Toronto, 1970 (Hulchanski, 2010)

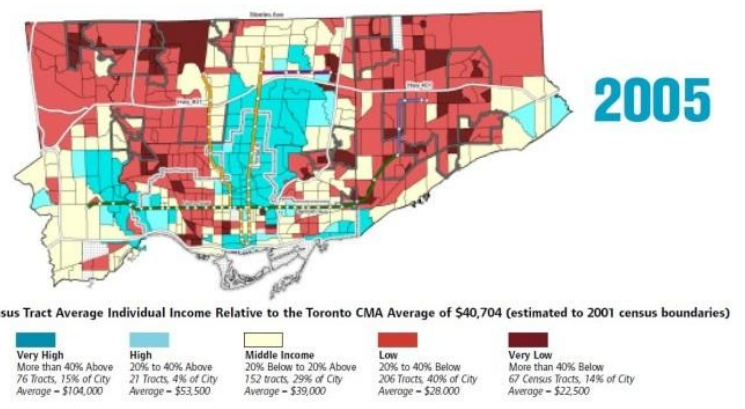

Figure 5: Average individual income, City of

Toronto, 2005 (Hulchanski, 2010) 
Hulchanski's study highlights that during the period of 1970 to 2005:

- High income areas are growing towards the core area and pushing low income areas out from the centre to the edges of the city.

Low income individuals that initially lived in the core of the city of Toronto have been pushed out due to the high costs of housing in the core. This phenomenon illustrates the lack of affordable housing choice for low income households to stay and live near to services and transit networks. Hulchanski states:

"It is common to say that people "choose" their neighbourhoods, but it's money that buys choice. An increasing number of people in Toronto have relatively little money and thus fewer choices about where they can live. Those who have money and many choices can outbid those without these resources for the highest-quality housing, the most desirable neighbourhoods, and the best access to services. When most of the population of a city is in the middle-income range, city residents can generally afford what the market has to offer, since they make up the majority in the marketplace and therefore drive prices in the housing market." (Hulchanski, 2007, p.10)

\section{- Middle income areas are shrinking in a major way.}

This does not indicate that middle income households moved to suburban areas. However it shows that the number of middle income earners in 1970 was significantly higher than 2005, resulting in growing the income gap in the city.

The above trends indicate that low and middle income neighbourhoods in the core area of Toronto are being gentrified. Given the location of transit networks in the core of the city, access of low and middle income households to transit and amenities is increasingly becoming limited.

Hulchanski has provided some recommendations to slow or reverse income polarization in Toronto's neighbourhoods. The Three Cities within Toronto study includes these recommendations; to create and use policies that make housing more affordable for low income households, to create mixed income neighbourhoods and to expand transit to City\#3.

As a response to Hulchanski's study, this paper focuses on increasing affordable density in middle and low income areas that have not been completely gentrified to increase income inclusive practices in the city. In addition to the expansion of transit networks to the edges of the city and to low income areas in City\#3, it is critical to maintain the access of low and middle income households to existing transit networks. This paper suggests that increasing affordable housing density in walkable areas of City\#2 and City\#3 and expanding housing choices in areas well served by transit can help low and middle income households to stay in their neighbourhoods.

The next section introduces alternatives for increasing density, the City of Toronto's planning context and Toronto's spatial capability for infill intensification. 


\section{3- Potential Areas for Growth}

There is a substantial need of affordable units for low and middle income households in areas well served by transit as the housing price is rising in these areas. However, increasing density in these areas can impact the integrity of the character of these neighbourhoods as a large portion of walkable areas of Toronto are located in established neighbourhoods with specific physical character.

Given the need for increasing affordable residential density in Toronto, it is necessary to understand where the city can accommodate the additional density. The direction of residential growth is affected by the city's morphology as well as planning designations of Toronto's Official Plan. Toronto's Official Plan, adopted by the City Council in 2002, is the guide of where and how the city will grow until the year 2031. This section reviews the defined direction of growth by Toronto's Official Plan and also summarizes how intensification has changed the morphology of Toronto and explores how the urban fabric of stable neighbourhoods of Toronto can accommodate more density while maintaining the integrity of the character of neighbourhoods so strongly outlined in the Official Plan.

\section{3-1- Residential growth in Toronto's Official Plan}

The Official Plan directs growth to areas that are well served by public transit, including Mixed Use Areas along Avenues, Centres and Downtown and away from residential neighbourhoods and green areas. The Official Plan states:

"Generally, the growth areas are locations where good transit access can be provided along bus and streetcar routes and at rapid transit stations. Areas that can best accommodate this growth are Downtown including the Waterfront, the Centres, the Avenues and the Employment Districts. A vibrant mix of residential and employment growth is seen for the Downtown and the Centres. The mixed use Avenues will emphasize residential growth..." (City of Toronto Official Plan, 2010, 2-3).

The Official Plan illustrates areas of growth in the Urban Structure map. Comparing Hulchanski's income maps and the Urban Structure map from the City of Toronto Official Plan (2010) indicates that considerable areas of low and middle income neighbourhoods are located in areas that the Official Plan identifies as Neighbourhoods and does not emphasize growth in these areas. 


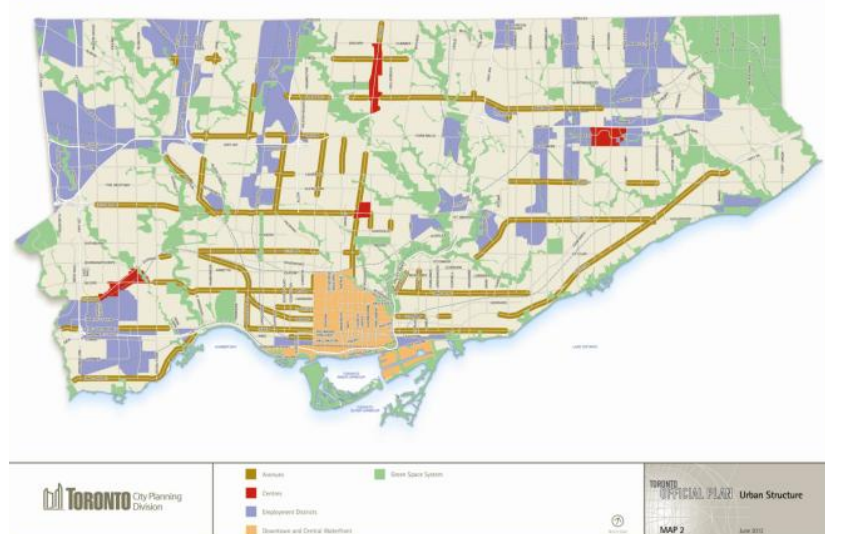

Figure 6: The Urban Structure map (City of Toronto Official Plan, 2010)

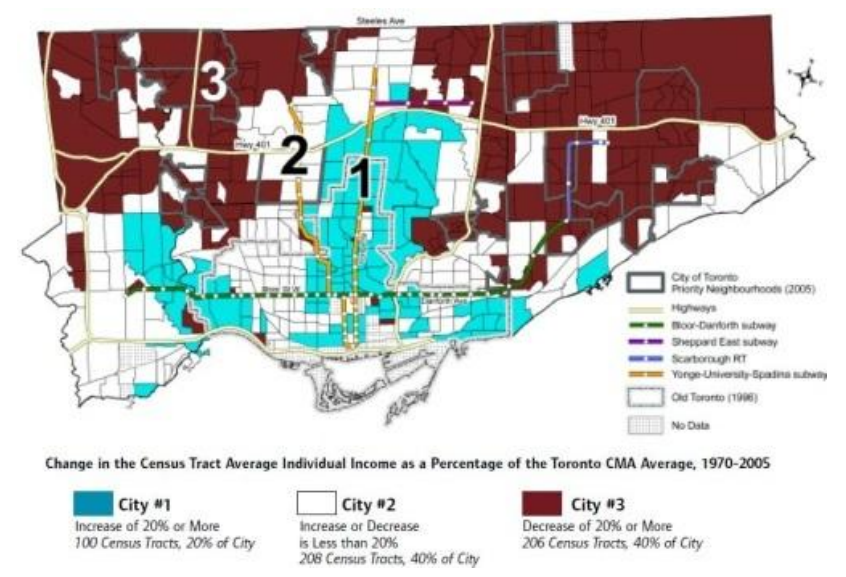

Figure 7: Hulchanski's income map (Hulchanski, 2010)

The Official Plan describes Neighbourhoods as:

"... physically stable areas made up of residential uses in lower scale buildings such as detached houses, semi-detached houses, duplexes, triplexes, townhouses, as well as interspersed walk-up apartments that are no higher than four storeys." (City of Toronto Official Plan, 2010, 4-3).

In addtion to the Downtown, Centres and Avenues as the growth areas of Toronto, the Official Plan highlights that change in Toronto's Neighbourhoods and green space system should emphasize "maintenance and enhancement" of these assets (City of Toronto Official Plan, 2010, 2-3). The Official Plan allows increasing density in stable neighbourhoods on the condition that additional density should maintain the physical character of the neighbourhoods.

\begin{abstract}
"Neighbourhoods and Apartment Neighbourhoods are considered to be physically stable areas. Development within Neighbourhoods and Apartment Neighbourhoods will be consistent with this objective and will respect and reinforce the existing physical character of buildings, streetscapes and open space patterns in these areas" (City of Toronto Official Plan, 2010, 2-22).
\end{abstract}

The Official Plan outlines the elements those shape and impact the physical character of a neighbourhood:

“a) Pattern of streets, blocks and lanes, parks and public building sites;

b) Size and configuration of lots;

c) Height, massing, scale and dwelling type of nearby residential properties;

d) Prevailing building type(s);

e) Setbacks of buildings from the street;

f) Prevailing pattern of yard and side yard setbacks and landscaped open space;

g) Continuation of special landscape or built-form features that contribute to the unique physical character of a neighbourhood; and 


\section{h) Conservation of heritage buildings, structures and landscapes." (OP-4-4-Policy 5)}

This study utilizes the above elements outlined by the Official Plan to define the physical character of a neighbourhood.

Increasing density in stable neighbourhoods and proximate to transit networks is in line with the Official Plan designations given that new density maintains the physical character of a neighbourhood. Currently this is being done through few laneway housing developments, as well as secondary suites and informal housing. Laneway housing is a detached form of infill housing which is secondary to a principal house and typically oriented towards a lane. Secondary suite is a self-contained space or enclosure within a dwelling unit designed for habitation by a separate family or household. Informal housing is a dwelling unit that does not comply with urban regulations. Laneway housing, secondary suites and informal housing provide an opportunity to accommodate a higher number of households in a given property while retaining the character of a neighbourhood.

\section{3-2- Toronto's Morphology and Incremental Change}

Understanding the historic and also the current trends of physical change in Toronto that are accommodating emerging housing needs provides more perspective on the impact of residential growth on urban fabric.

Toronto was founded on the north shore of Lake Ontario. In the 18th century, Toronto grew to become a settlement of square blocks along the waterfront. By the early nineteenth century, Toronto expanded beyond its established grid. Land was "divided into long and narrow parcels [that were] 182 metre wide. These parcels were conceived as large estates for the military and the wealthy" (Shim, Chong and others, 2004). During the mid- $19^{\text {th }}$ century individual land owners began selling their large estates although there was not any systematic approach throughout the city for lot division (Shim, Chong and others, 2004 and Stinson and Van, 2003). The unplanned land division created diverse lot division within large estates. These large estates developed individual neighbourhood qualities for large areas and eventually "the city of neighbourhoods" was created. Toronto developed a reputation for its neighbourhoods in addition to its consistent commercial arterial street frontage

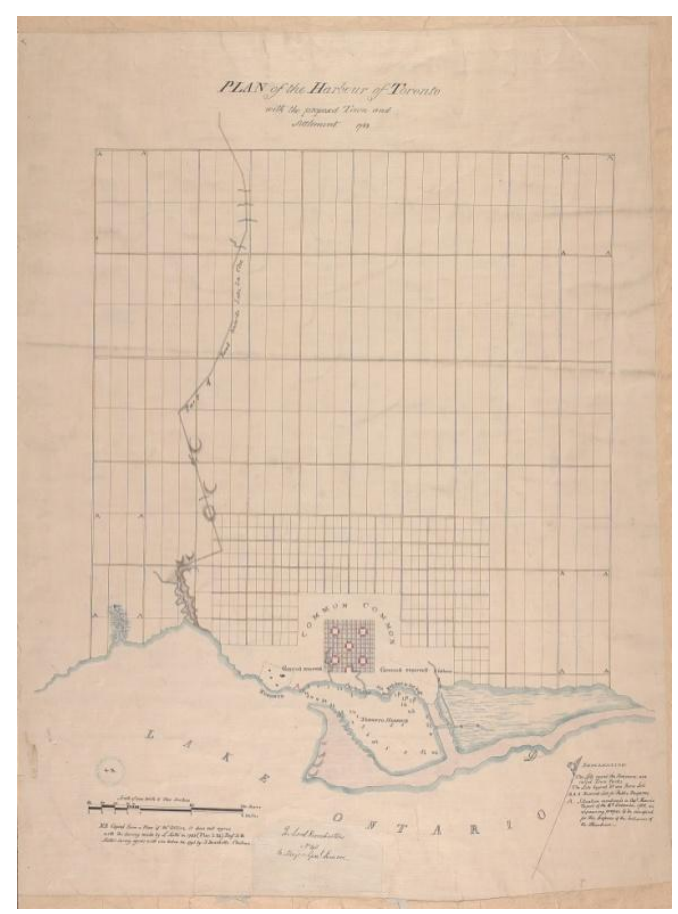

Figure 8: Plan of the harbour of Toronto with the proposed town and settlement, 1788 (Toronto Public Library, 2014) developments of 2-3 storeys. When a large estate property was divided into smaller lots, then street layouts were created and each lot was subdivided into smaller lots. Buildings were constructed along streets and lanes provided 
access to the back of the buildings. As the city grew this incremental change has enabled the city to maintain its neighbourhood character and livability while accommodating new density (Baird and Myers, 1978).

Today Toronto accommodates new residential density mainly through land assembly developments and condominiums in high rise developments. These housing developments can impact the urban fabric and can change the character of a neighbourhood. Currently a common option for increasing residential density is to assemble land with adjacent neighbours and build a new low rise, mid-rise or high rise apartment. During the past decade Toronto has experienced an enormous growth in condominiums developments. In the period of 2005 to 2012, approximately three-quarters of all housing developments in the City of Toronto were condominiums (Robinson, 2013). Toronto City Planning states "The construction of condominium apartment units in Toronto has outstripped all other forms of housing construction” (Profile Toronto September 2006, 1). Condominiums or land assembly developments can affect the physical character of a neighbourhood by changing the pattern of lot division, open space, height and building envelope while small unit developments have more flexibility to retain the neighbourhood character.

George Baird's essay, "Vacant Lottery” (1978), highlights the contrast between historic incremental change and the process of land assembly witnessed today. By 1960 the pattern of lot division became less common and land assembly accelerated. In contrast to lot division approach, increasing density through land assembly changes the scale of buildings and lots and gradually changes neighbourhood character. The new infill developments are "increasingly indifferent to their neighbours" (Baird, 1978). Baird (2004) argues that currently condominium developments in Toronto drastically change the character of stable neighbourhoods. He encourages intensification which maintains neighbourhood physical character (Baird, 2004 and Cubitt, 2008). It is this question of how to increase density while retaining the physical character of a neighbourhood that this study addresses.

Incremental intensification is recognized as an alternative to the high rise / high density North American city with its sprawling suburbs (Myers, 1978). Incremental intensification adheres to neighbourhood character and tends to enhance existing urban fabric rather than proposing large scale developments. Smaller housing typologies such as laneway housing and secondary suites provide an opportunity for increasing density and reducing impact on urban fabric. Currently the share of small housing developments in residential growth in Toronto is very small and mainly promoted by individual home owners, not by the City. Toronto's Official Plan does not provide a particular guideline for incremental intensification. However the Official Plan recognizes small scale residential growth in stable neighbourhoods on condition that new developments maintain and reinforce the physical character of the neighbourhood.

Currently there is an emerging interest for incremental intensification through laneway developments in Toronto. Secondary suites and informal housing are other forms of small unit housing observed in Toronto increasing residential density and retaining neighbourhood character. The next section discusses laneway housing, informal housing and secondary suites as alternatives for incremental intensification. 


\section{4- Options of Small Scaled Affordable Housing}

As Toronto seeks opportunities to expand housing choices in stable neighbourhoods, there is an opportunity for the addition of a new layer of housing density in back lanes. The addition of secondary suites to existing residential properties provides an opportunity to increase affordable housing choices in already dense neighbourhoods (Gellen, 1985 and Wegmann, 2014). Laneway developments have been identified as a way to incrementally increase density and at the same time respect and reinforce the physical character of a neighbourhood (Baird and Myers, 1978). Informal housing is another typology of affordable housing. It can be argued that informal housing is a response to the lack of affordable housing (Aravena, 2012). This section reviews the application of secondary suites, laneway housing and informal housing in Toronto.

\section{4-1- Secondary Suites}

According to the City of Toronto's Zoning By-law (2013) "second suite means a self-contained space or enclosure within a dwelling unit designed for habitation by a separate family or household, and which shall contain at least one room, a kitchen and sanitary conveniences designated for the exclusive use of its occupants". Secondary suites are small size housing units and this quality makes them one of the viable means to increase housing affordability while respecting neighbourhood character. Secondary suites assist owners to generate income within their principal residence, cope with debt and maintain their properties (Gratton, 2011, Planner A, 2014 and Ruud and Nordvik, 1999). Similarly secondary suites are an affordable choice to rent. These dwelling units tend to be cheaper than comparable rental units in multifamily housing (Wegmann, 2014) and contribute positively to the rental stock in Toronto. These units can promote mixed income neighbourhood by enabling households with a wide range of income to stay and live in a same neighbourhood (Gratton, 2011).

Provisions of Ontario Planning Act state that municipalities shall authorize second suites through their official plans and zoning by laws. In addition Ontario Provincial Government allows secondary suites to be built "within dwellings or within structures accessory to dwellings (such as above laneway garages)" (Ontario Ministry of Municipal Affairs and Housing, 2011). Section 150.10 of the City of Toronto's zoning by law has authorized secondary suites under specific requirements. As the provincial government in Ontario requires municipalities to facilitate the creation of secondary suites, there is an opportunity to address laneway housing in Toronto as a type of secondary suite. 


\section{4-2- Laneway Housing}

Historically, laneway networks in Toronto provided an opportunity for creating density, providing access to services and increasing efficiency of land uses. Laneways system in Toronto is a particular pattern of land development in the City.

Providing access to the back of buildings has been the main role of the laneway network in Toronto (Shim, Chong and others, 2004). For years laneways have been discussed as a place of lost opportunity in design circles. Today garages and graffiti are two main features in Toronto's laneways. As the housing market has become more expensive previously 'undevelopable' lots become economically feasible to be developed.

As mentioned earlier, laneway housing is a detached form of infill housing which is secondary to a principal house and typically oriented towards a lane. Apart from vernacular laneway houses in Toronto, an emerging interest in laneway housing has been developed since 1990s and early 2000s as a means to increase residential density (Cubitt, 2008). In the 1990s a few iconic laneway houses were constructed by architects.
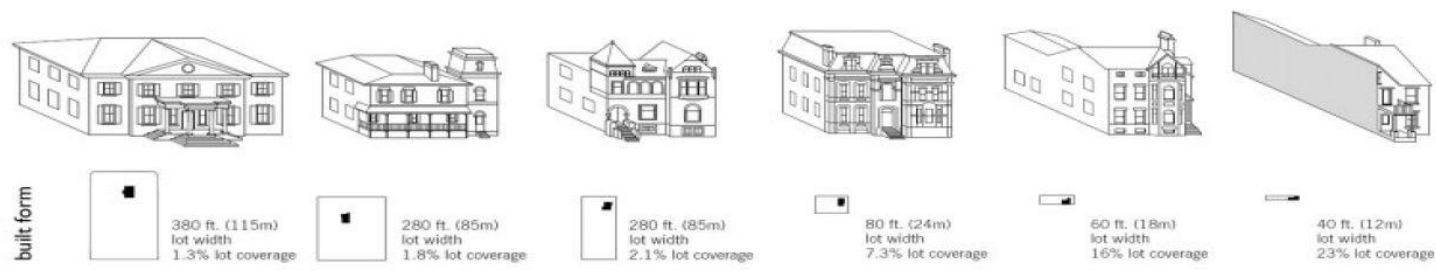

$-$
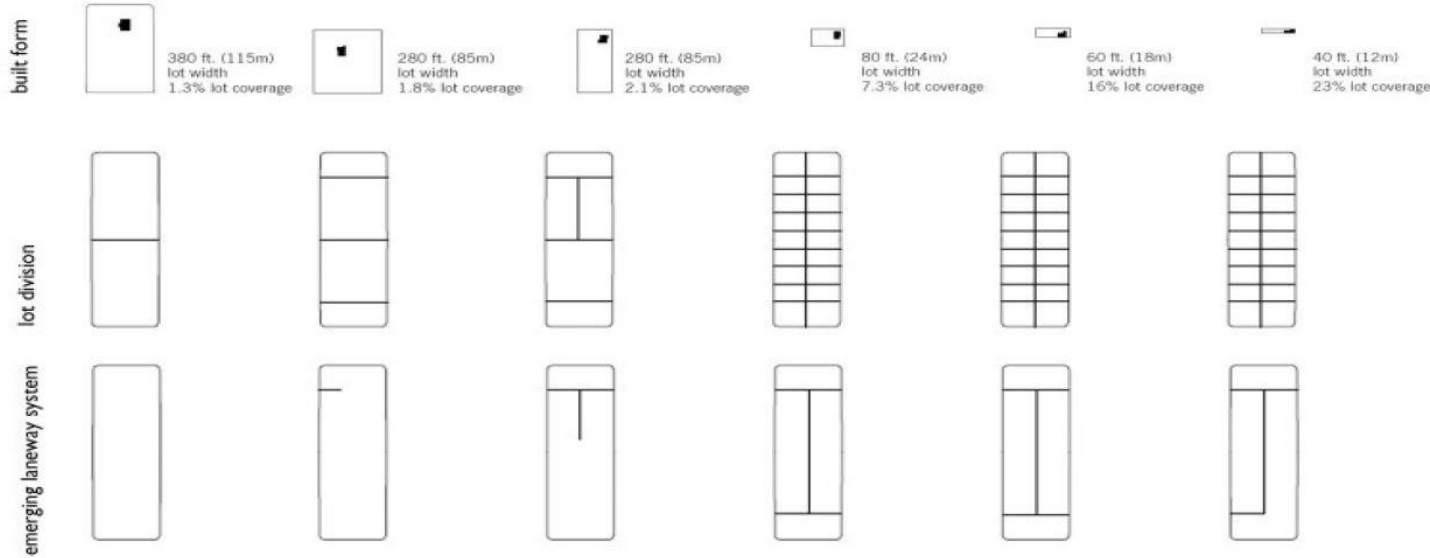

Figure 9: Incremental subdivision of a typical Toronto block into smaller lots (Shim, Chong and others, 2004).

In 2003, under the Affordability and Choice Today (ACT) program, Canada Mortgage and Housing Corporation (CMHC) published a comprehensive study on "Laneway Housing in Toronto". In this study, Jeffery Stinson and Terence Van Elslander Architect suggest that laneway housing is a viable choice for infill housing, and for accommodating new residential density in the inner city. The study also provides some technical recommendation for implementation (Stinson and Van, 2003). 


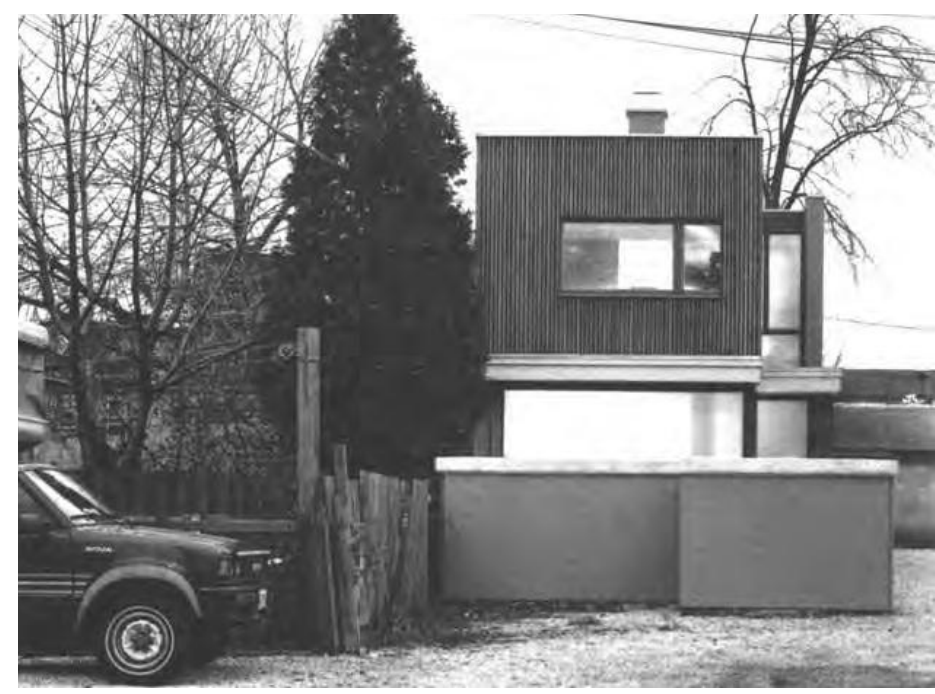

Figure 10: 7 Leslie Garden Lane Shim - Sutcliffe Architects, 1993 (Stinson and Van 2003)

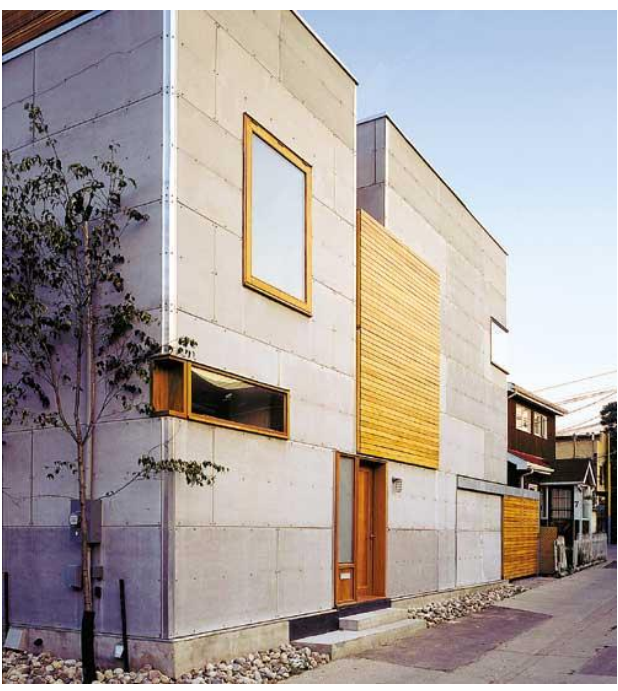

Figure 11: 1 Ways Lane A.J. Diamond \& Donald Schmitt \& Company Architects, early 2001 (City of Toronto website)

Baird and Myers in "Vacant Lottery" also proposes a "low rise manifesto" as an alternative to high rise and sprawling developments. They put the emphasis on urban renewal, reuse of existing structures and infill housing. Laneway housing can incrementally increase residential density. Such increase in density creates more compact residential neighbourhoods which can promote livability, walkability and safety.

A neighbourhood with laneway housing offers a variety of housing choices, in size and cost, and thus attracts a wide range of households including low and moderate income individuals. As Hulchanski recommends promoting mixed income neighbourhoods in areas near to transit, large part of these areas are located in the core of the city, have laneways and laneway housing is a possibility to expand housing choices and increase affordability in these areas.

Affordable laneway housing encourages personal investment and this can generate wealth. Baird (2004) argues that reuse of existing urban fabric "will be energy saving in terms of transit, services, built form and land use". Laneway housing, as a way to better use of built up area, aims to increase efficiency of land use and infrastructure which can lower the cost of housing.

\section{4-2-1- Planning Context and Approval Process}

Despite the value of laneway development, the City of Toronto is reluctant to promote laneway house construction. The City does not permit laneway construction except for special circumstances (Crowther and City of Toronto, 2006). The City argues that there are planning, engineering and servicing considerations associated with laneway developments such as privacy, overlook, shadowing and servicing. Servicing issues include firefighting access, water and sewage, electricity, garbage collection, winter maintenance and storm water 
management (Crowther and City of Toronto, 2006). It is costly to address privacy, overlook and servicing issues for any development either laneway housing or condominium development. The city argues that servicing considerations for laneway developments is major and complicated compared to other types of housing while servicing complications can be addressed through policy and design guidelines (Planner A and Planner C, 2014). For example firefighting access can be provided from front street, or from laneways by using mini firefighter vans (Planner A, 2014).

The city's Zoning By-law No. 569-2013 in Residential Chapter does not permit an addition of a building with dwelling units in the rear of another building. Toronto's Zoning By-law states that:

"In the $R$ [Residential] zone, a building, or an addition which is not attached above-ground to the original part of a building, is not permitted if:

(A) It has dwelling units and is in the rear of another building or the original part of the same building; or

(B) It is in front of a building, or the original part of the same building, with dwelling units, so as to produce the condition of a building with dwelling units in the rear of another building." (City of Toronto, 2013)

Another document on laneway housing by the City is a staff report in 2006 which recommends:

"(1) The City not permit construction of housing on existing laneways, except in special circumstances where there are no adverse privacy, overlook, shadowing and engineering servicing implications; and

(2) The City not permit construction of housing on proposed/future laneways." (Crowther and City of Toronto, 2006)

The City made the above recommendations based on planning and also engineering issues associated with laneway developments. There are other Canadian cities adopting laneway housing. For example, Vancouver has employed laneway housing developments to increase "the diversity of rental units in single family neighbourhoods" (City of Vancouver, 2013). In 2009 Vancouver City Council adopted "Laneway Housing Regulations and Guidelines" and in 2013 added several amendments to this document in response to issues such as privacy and parking. Laneway housing developments in Vancouver face the same issues as Toronto, including privacy, overlook, shadowing and servicing considerations. However Vancouver has approached these issues differently by creating a guideline for laneway housing development. Given the potential for residential growth in stable neighbourhoods of Toronto through laneway developments, it will be truly valuable if the city employs Vancouver's experience, creates Toronto's guideline for laneway developments and adopts zoning amendments allowing laneway development.

Currently Toronto has a case by case approval process for laneway housing development which is much more expensive and longer than other comparable development processes. The steps of the approval process 
begin with the submission of a proposal for Preliminary Zoning review. This review will identify non conformities in the proposed project. Depending on the nature and degree of the non-conformities with the existing Zoning Bylaw and the Official Plan, an applicant may require applying for minor variances through the Committee of Adjustment, zoning amendment, Official Plan review or Site Planning approval. If the applicant is not satisfied with the result of the approval process, she or he can appeal to the Ontario Municipal Board (OMB). As the city does not currently support laneway housing, there is a general lack of awareness on the potential benefits of laneway developments and as such a large number of applications end up at the OMB for decision. Such a long complicated approval process is time consuming and costly both for applicants and the City. It can be argued that the existing approval process in Toronto lowers affordability and only those who have the knowledge as well as financial resources, mainly architects, can go through the current approval process.

In addition to the complicated approval process and servicing issues, community resistance is another barrier for adopting a laneway housing policy and also for individual laneway developments. Privacy, shadowing and overlook associated with laneway developments are the main reasons for community opposition. Increasing public awareness about how design and policy guidelines can address privacy, shadowing and other concerns about laneway housing developments and also about the benefits of laneway developments for the city can generate public support.

Although this study recognizes challenges associated with laneway developments, the study focuses on how much density can be added through laneway developments and how these developments influence and maintain neighbourhood morphology.

\section{4-3- Informal Housing}

Informal housing is an extra legal activity and includes those dwelling units that do not comply with urban regulations. These are some examples that can be considered informal housing; a duplex house with five separate units, a non-registered basement suite, a non-registered secondary suite, a converted garage to a dwelling unit or a suite located above a garage. Informal housing as a broad topic is typically associated with the Global South and a large share of theoretical body on informal housing is based on the Global South experience. Recently there is an emerging attention by scholars to informality phenomenon in high income countries (Mendez, 2011 and Wegmann, 2014) and the role of informal housing in increasing housing choice, density and affordability.

Informal housing is a means to deal with housing affordability problem by providing a cheap housing option to rent and generating income for home owners (Aravena, 2012 and Wegmann, 2014). Informal housing is a phenomenon outside of conventional planning process, indicating a need for affordable housing. Census data and housing market information is very limited on data about informal housing especially in developed countries. Housing scholars suggest various methods to identify informal housing, for example field observation and study 
and analysis of physical signs suggesting informality such as the number of mail boxes, the number of ring bells and the number of hydro meters (AISayyad, 2004 and Planner A, 2014).

Informal housing is cheaper than other comparable units in a same neighbourhood due to the lower cost of maintenance such as the costs of municipal inspection and new hydro connection. The lower cost of housing enables low and middle income individuals to live in desired neighbourhoods, close to services and transit. Also informal units increase home ownership affordability by generating income for owners. Given the nature of informal activity, informal housing units are almost physically hidden within a neighbourhood and as a result preserve neighbourhood character.

Laneway housing, secondary suites and informal housing are small scale housing solutions that increase affordability for both owners and tenants while maintaining the character of neighbourhoods. The next section illustrates a set of methods for testing these alternatives on a study area in Toronto. 


\section{5- Methodology}

As middle and low income areas of Toronto in proximity to transit networks are being replaced by high income neighbourhoods, it is necessary to increase affordable housing choices in these areas to maintain the access of middle and low income individuals to services and public transit. This study employs a set of methods to investigate how affordable density in middle and low income areas of Toronto near to transit networks can be increased while maintaining the character of a neighbourhood. This study identifies the location of potential areas for increasing affordable density in the low and middle income neighbourhoods in the city of Toronto. Also it explores the role of laneway housing, secondary suite and informal housing in providing affordable units for low and middle income earners in Toronto, as the addition of these types of housing can maintain the character of a neighbourhood while increasing density. Lastly, this paper examines various possibilities for incremental intensification through laneway developments and informal housing.

This section describes the research methodology in four types of methods:

- $\quad$ Semi-structured Interviews

- $\quad$ Mapping and Spatial Analysis

- $\quad$ Field Research

- Development of Scenarios

Semi-structured Interviews with housing professionals and researchers were employed to obtain information about affordable housing and particularly to identify challenges and opportunities for laneway developments and informal housing in Toronto. Mapping and Spatial Analysis identifies areas of Toronto that are in need of income units geared to lower and middle income earners due to proximity to transit and laneway morphological structure. Field Research describes method of collection test site and lastly, Development of Scenarios defines and tests various scenarios for increasing housing density while maintaining the physical character of a neighbourhood.

\section{5-1- Interviews}

This study utilizes semi-structured interviews with a number of housing professionals and academic researchers to develop a better understanding about housing choices, affordability and informal housing in Toronto. Interviews are effective at obtaining first-hand information to "fill gaps in knowledge that other methods are unable to bridge conclusively" (Neuman, 2010 and Valentine 2005). In order to conduct interviews, an approval from the Ryerson University Research Ethics Board was received after the completion of the Online Ethics Protocol Submission and Review System describing the study and its perceived risks. Also an invitation letter, a participant consent form and an interview guide were created and attached to the Ethics application (See Appendix A for Ethics Approval Letter, Appendix B for Interview Guide and Interview Consent Forms). 
Participants for interviews were identified based on their expertise and knowledge of laneway housing and informal housing in Toronto. Respondents were recruited through email and provided with a letter of invitation. Interviews were conducted in person and the following topics were discussed with participants:

1- Informal housing in Toronto: key drivers, benefits and problems for both the middle income class and the City of Toronto.

2- Alternatives to informal housing to increase affordability in the inner city.

3- Laneway housing in Toronto: the opportunities and challenges for both the middle income class and the City of Toronto.

During the interviews detailed notes were taken and afterward the notes were analyzed to expose key themes. The results of the interviews were used in this study to understand the role of secondary suites, informal housing and laneway housing in increasing density and affordability in Toronto and also to identify challenges for laneway housing and secondary suite developments in the city.

\section{5-2- Spatial Analysis and Mapping}

This study investigates how to increase housing choices for low and middle income individuals in areas near to transit networks. To address this question those middle and low income areas of Toronto that are well served by transit and have laneway structure were identified by mapping and spatial analysis. Three criteria were defined to identify the area of study:

Criterion 1: The area needs to be within Hulchanski's City\#2 or City \#3 of low or middle-income both in 1970s and 2005s.

This criterion identified those areas in need for low and middle income units. Those areas accommodating low and middle income earners from 1970 to 2005 were identified as potential areas for increasing affordable housing choices. It is important to provide affordable housing for middle and low income households in the core areas of the city to enable them living close to services and transit. Otherwise, as Hulchanski's research demonstrates middle income neighbourhoods continue shrinking, and low income households are continuously pushing out from the inner city (Hulchanski, 2010).

To identify eligible areas under Criterion 1, Hulchanski's income maps of 1970 and 2005 were used and modified. First, middle and low income areas in 1970 and also in 2005 were illustrated in two separate maps (Figure 12 and 13), then an overlay of these two was created to reveal parts of Toronto that have been in low and middle income areas both in 1970 and 2005 (Figure 14). 


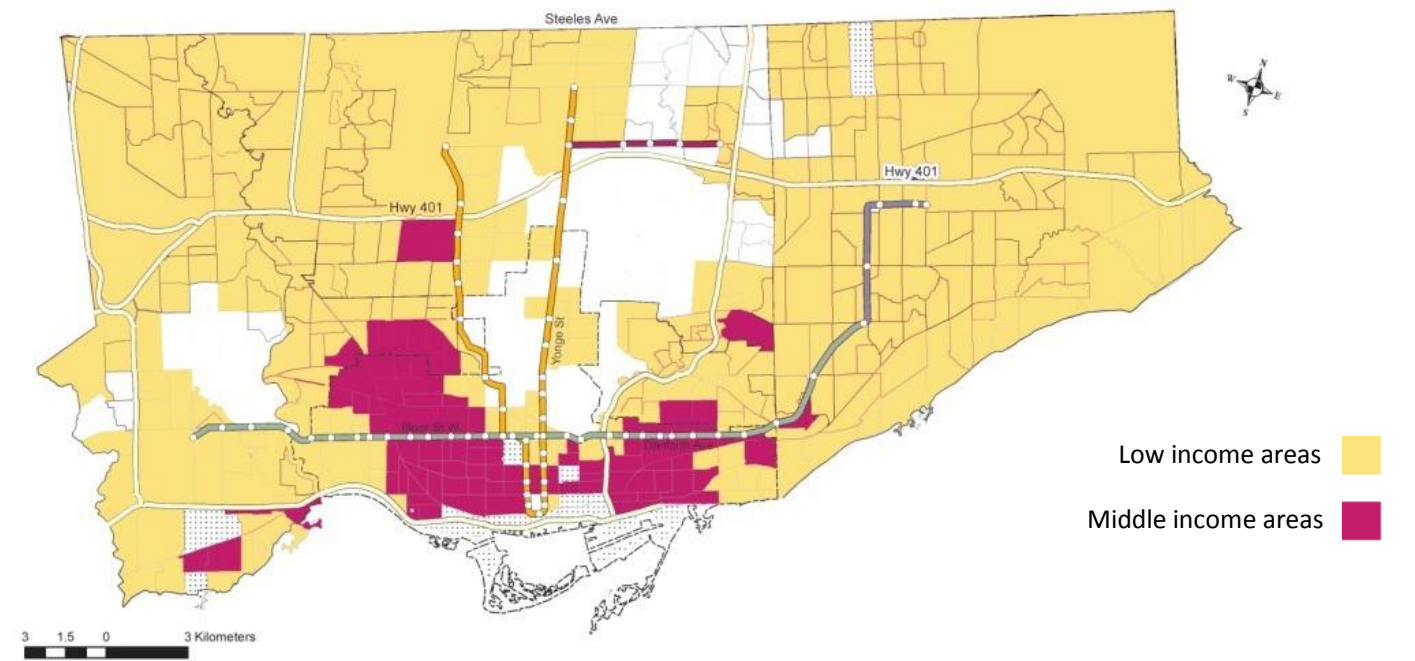

Figure 12: City \# 2 and City \# 3 in 1970 (Hulchanski, 2010, edited by author, 2014)

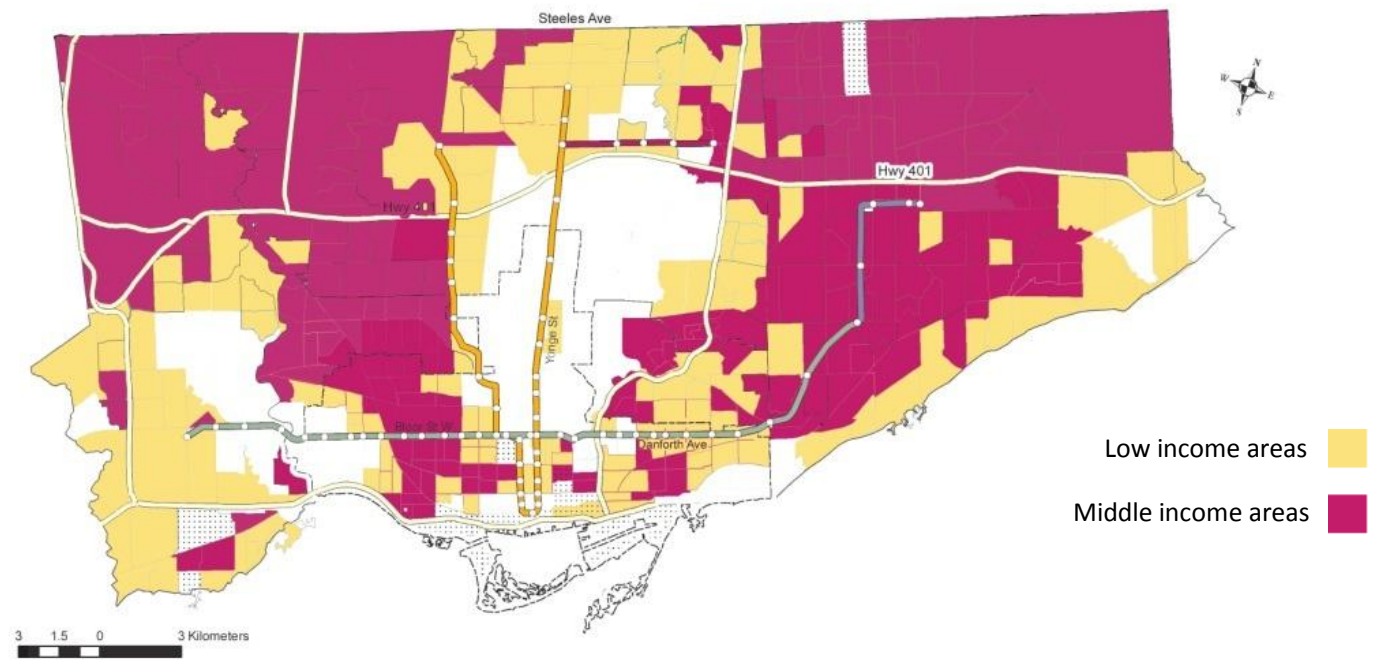

Figure 13: City \# 2 and City \# 3 in 2005 (Hulchanski, 2010, edited by author, 2014)

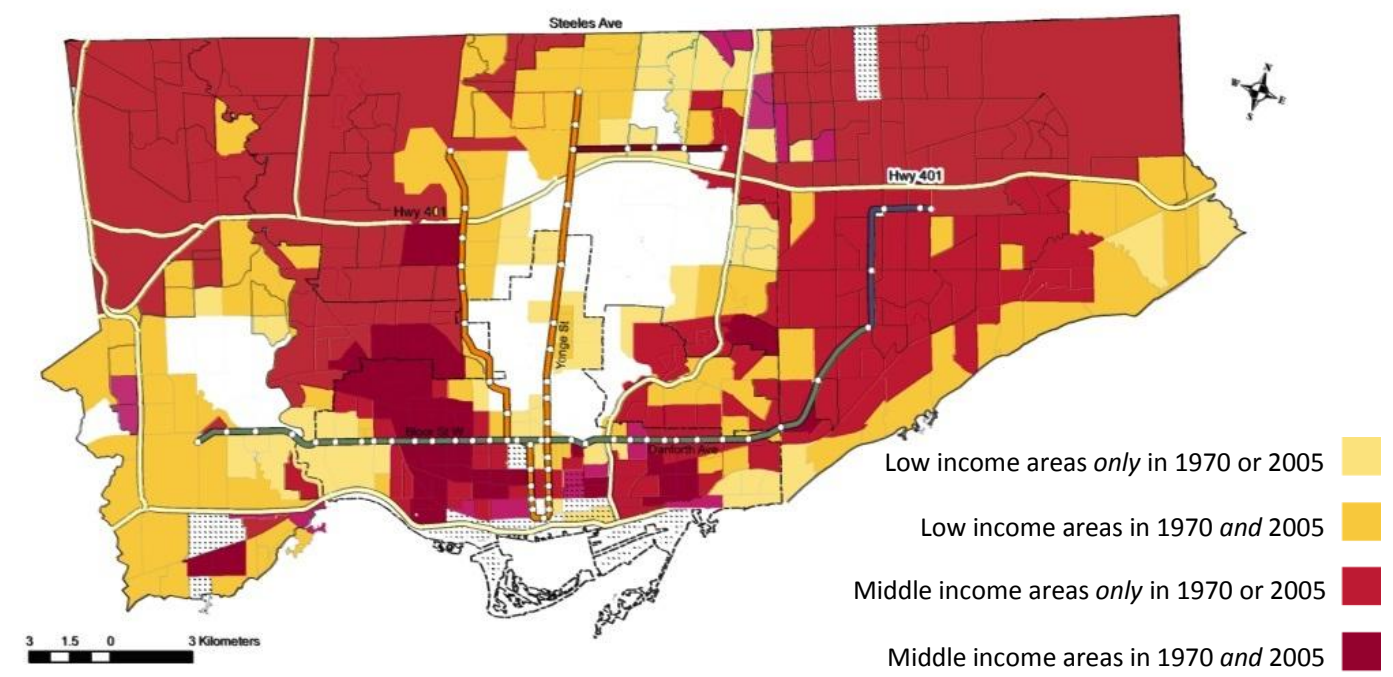

Figure 14: City \# 2 and City \# 3 in 1970 and 2005 (Hulchanski, 2010, edited by author, 2014) 


\section{Criterion 2: The area must be walkable and close to transit network.}

Hulchanski's research shows that middle and low income areas in proximity to transit networks are being replaced by high income neighbourhoods. Low and middle income earners are pushed out from the walkable areas of the city due to the high cost of housing in these areas. Despite this trend of gentrification, there are still middle and low income neighbourhoods close to public transit. Providing affordable housing in these areas can allow low and middle income earners to stay and live close to transit networks.

Walkable areas in middle and low income neighbourhoods of Toronto are illustrated in Figure 16. This is an overlay of Figure 14 and the City of Toronto Walkability map. Figure 15 presents highly and moderately walkable areas of the city.

Laneway developments can provide small affordable housing units while maintaining neighbourhood character. Comparing Figure 14 to the Urban Structure map shows that areas in need of middle and low income units are mainly located in stable Neighbourhoods. According to Toronto's Official Plan infill developments in stable neighbourhoods should respect and reinforce the physical character of neighbourhood (Toronto Official Plan, 2010). Small scale developments in back lanes can increase housing choice and also can preserve neighbourhood character, therefore the next criterion is to explore the areas of the city that have the potential for laneway development.

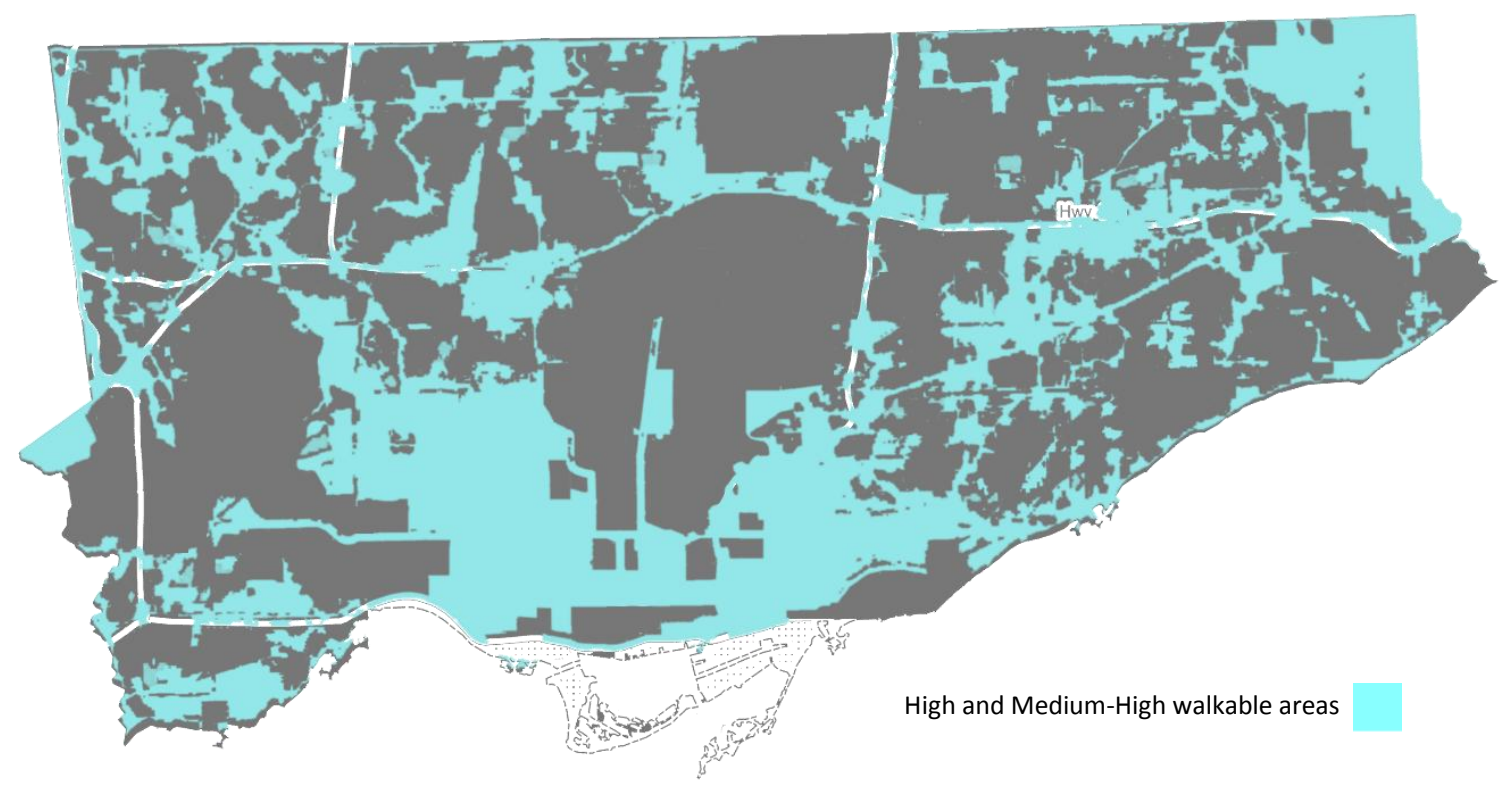

Figure 15: Walkable areas of Toronto (City of Toronto, 2012, edited by author, 2014) 


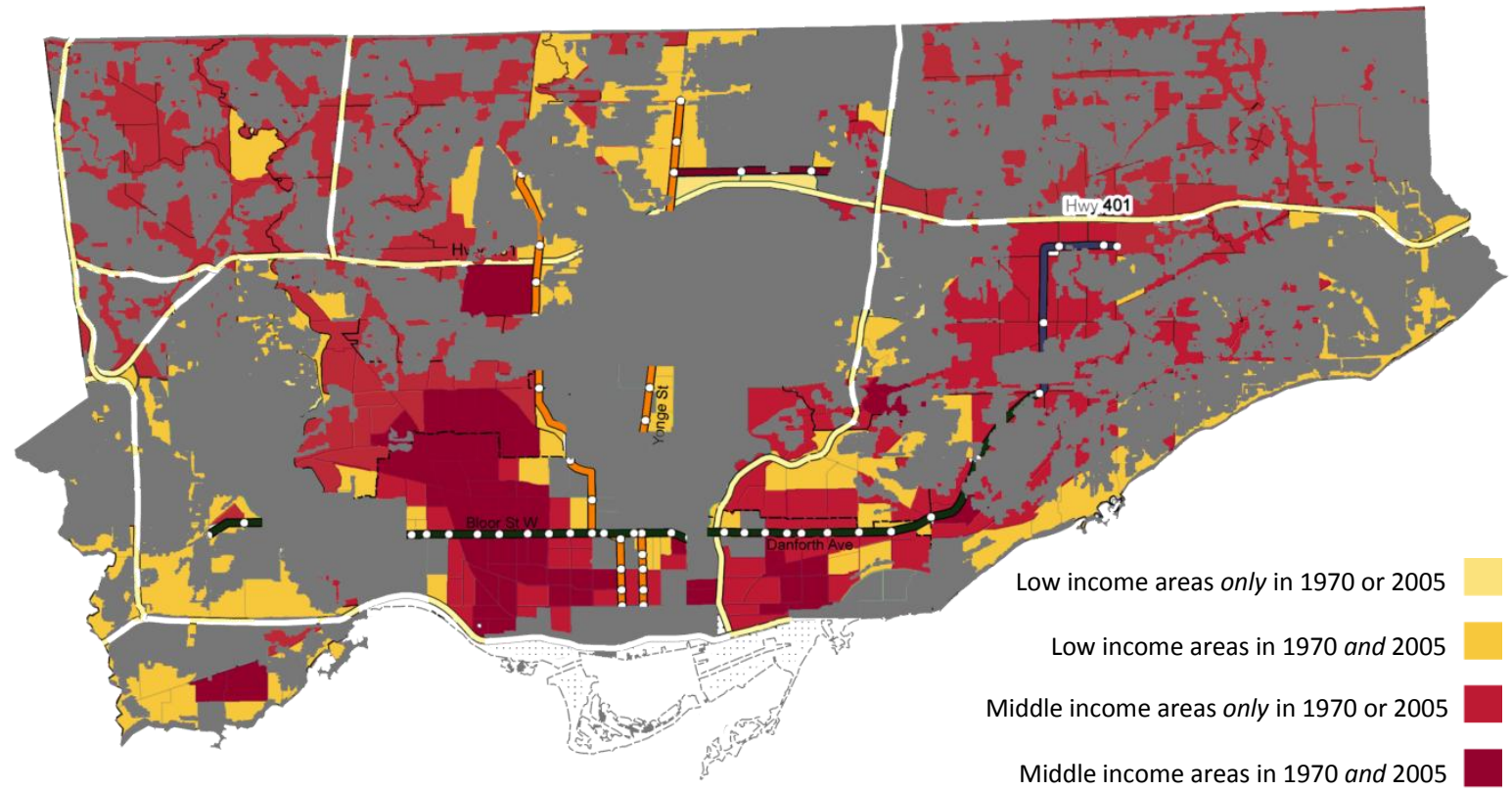

Figure 16: Walkable areas in City\#2 and City \#3 of Toronto (City of Toronto, 2012 and Hulchanski, 2010, edited by author, 2014)

Criteria 3: The area needs to have laneways.

Laneway developments provide an opportunity to incrementally increase density (Baird and Myers, 1978). Additionally laneway developments can provide small affordable housing and also maintain neighbourhood character. To identify the location of laneways in the city and potential areas for laneway development, the GIS map of the walkable parts of City\#2 and City\#3 was compiled by assembling 247 individual maps of Toronto from the year 2012. The access to individual GIS maps was provided by the Geospatial Map and Data Centre in the Ryerson University Library.

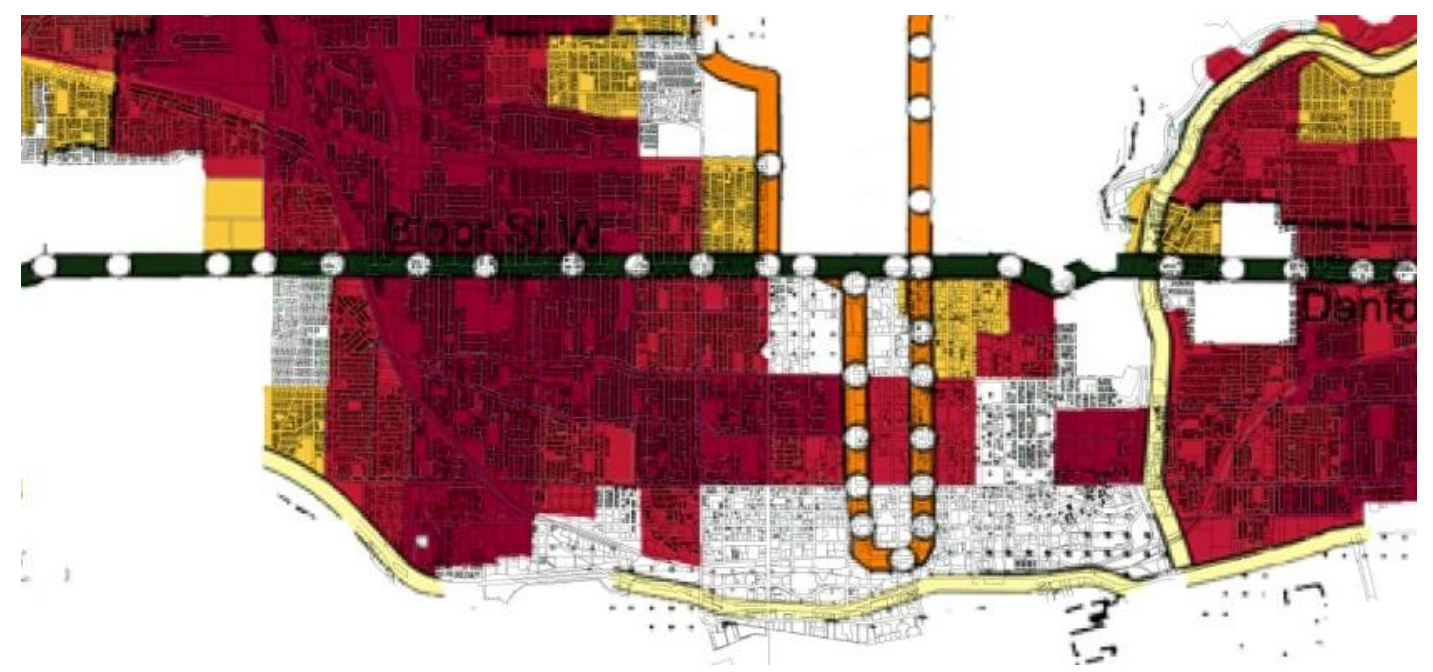

Figure 17: The GIS map laid on top of the Walkable areas in City\#2 and City \#3 (Figure 16) (City of Toronto, 2012 and Hulchanski, 2010, Ryserson University, edited by author, 2014) 
In the next step a test area was selected to test various scenarios for increasing density while maintaining neighbourhood character. Based on the location of laneways and also the size and shape of lots potential test areas were identified. Two criteria were considered for site collection:

- Test area should have typical lot size and lot shape, and should have both small and narrow lots in order to increase replicability of the study;

- Test area needs to have informal housing to justify the need for the addition of residential density. This criterion was defined as the existence of informal housing in a neighbourhood suggests that the area is in high demand for increasing density and additional dwelling units.

Based on the first criterion, three potential test areas were initially selected from the compiled GIS map; one located in Parkdale, one in Trinity Bellwood and the other one in Palmerston neighbourhood. The second criterion was tested through initial site visits. Initial site visit for all three areas were conducted to obtain an understanding about the level of ongoing housing informality and also about the physical and spatial capacity of test areas for increasing density. The initial observations indicated that test areas in Parkdale and Trinity Bellwood do not have a considerable level of informality while in the selected area in Palmerston many elements were observed suggesting the existence of informal housing. The study area in Palmerston was selected as the test area as a result of the amount of observed housing informality, and also due to the fact that this area has typical both narrow and wide lots which increases the repeatability of the study in other areas of Toronto. The test area includes three residential blocks with laneways located west of Bathurst Street and south of Harbord Street.

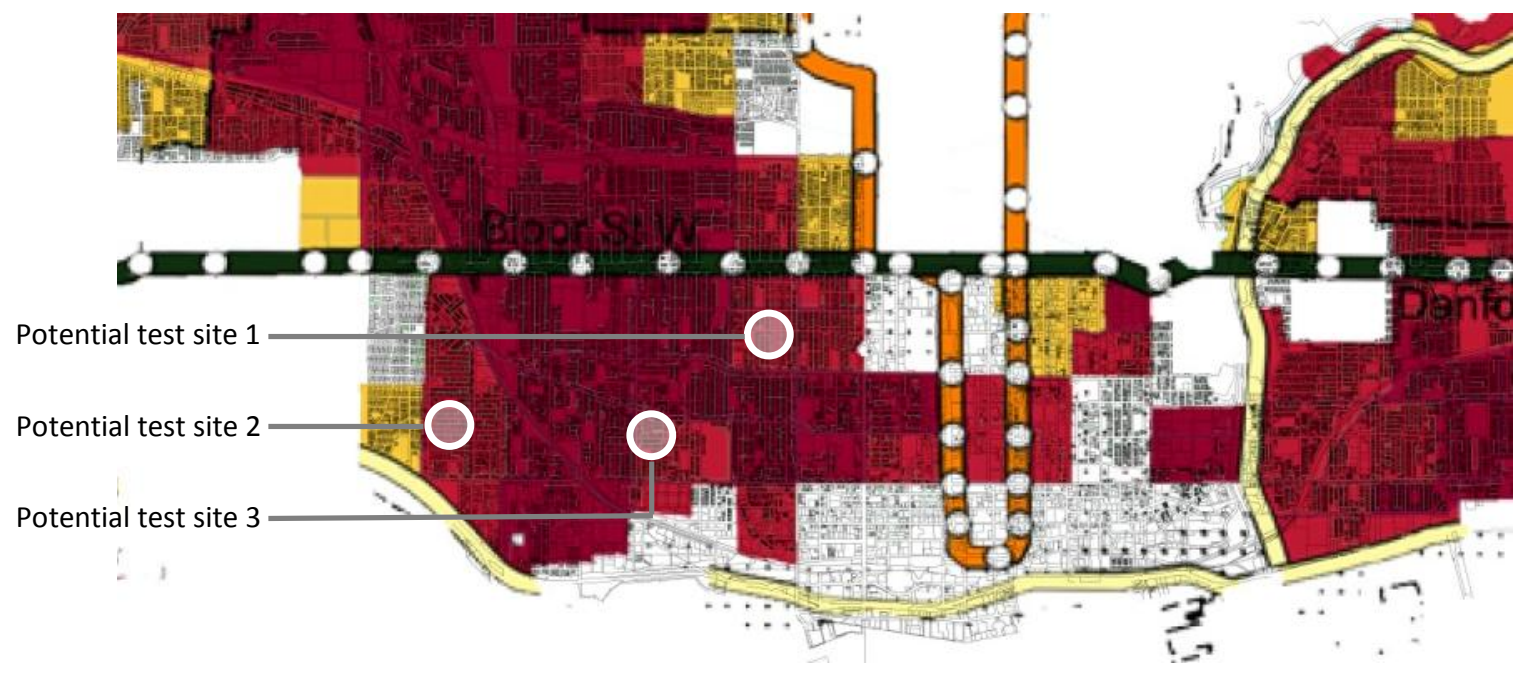

Figure 18: Potential study areas for testing scenarios (Ryserson University, edited by author, 2014) 


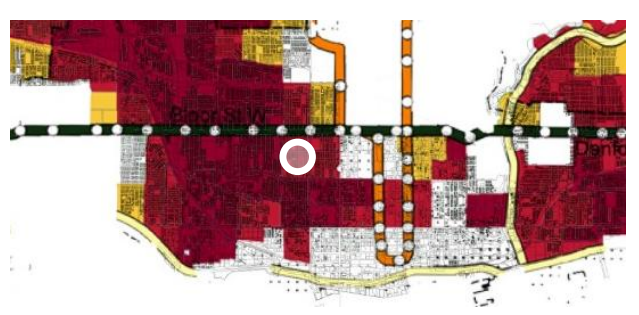

Building

Key map

Garage
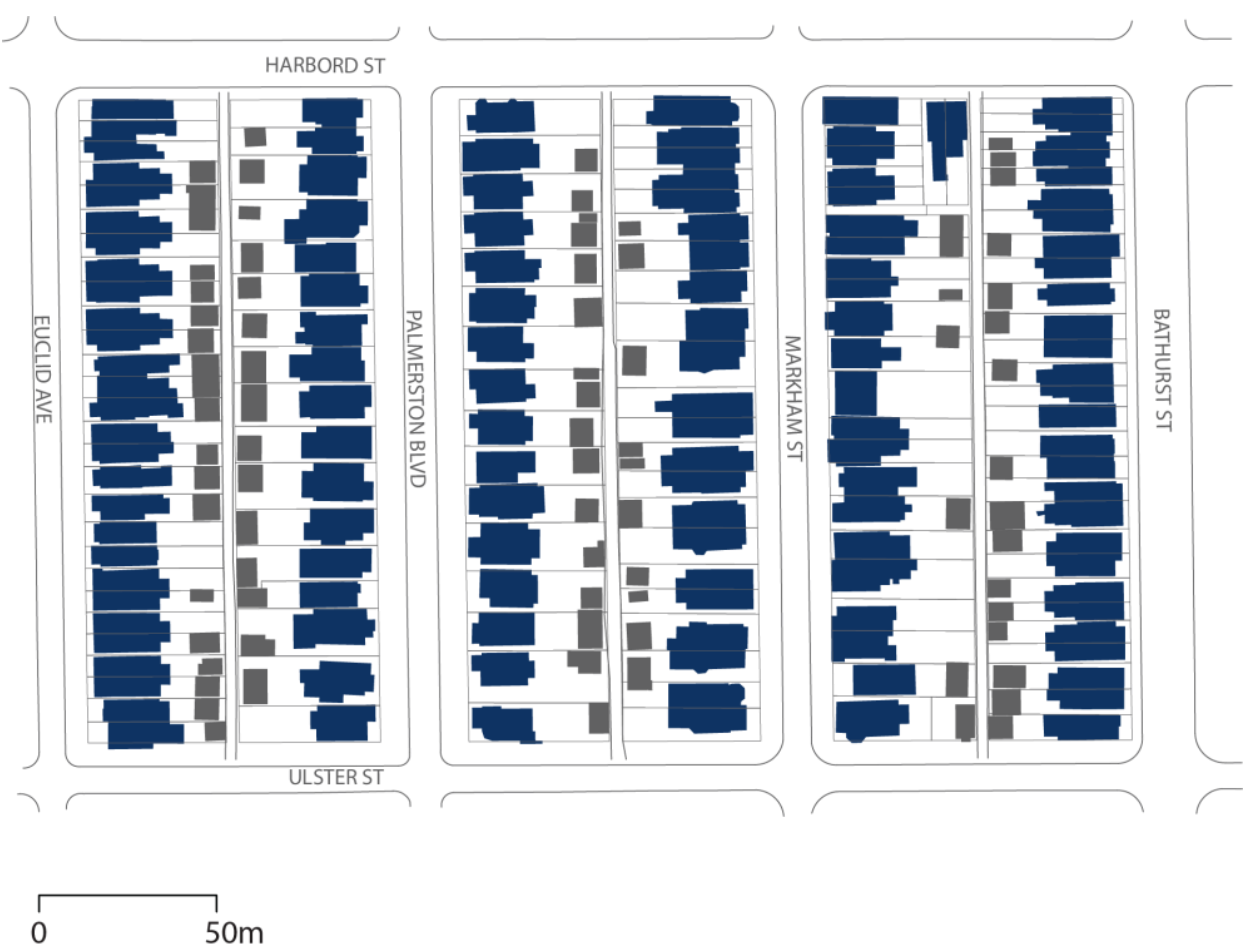

Figure 19: Potential test site 1 in Palmerston neighbourhood in Toronto (Image by author, 2014)

Original map from: Ryerson University, 2014 


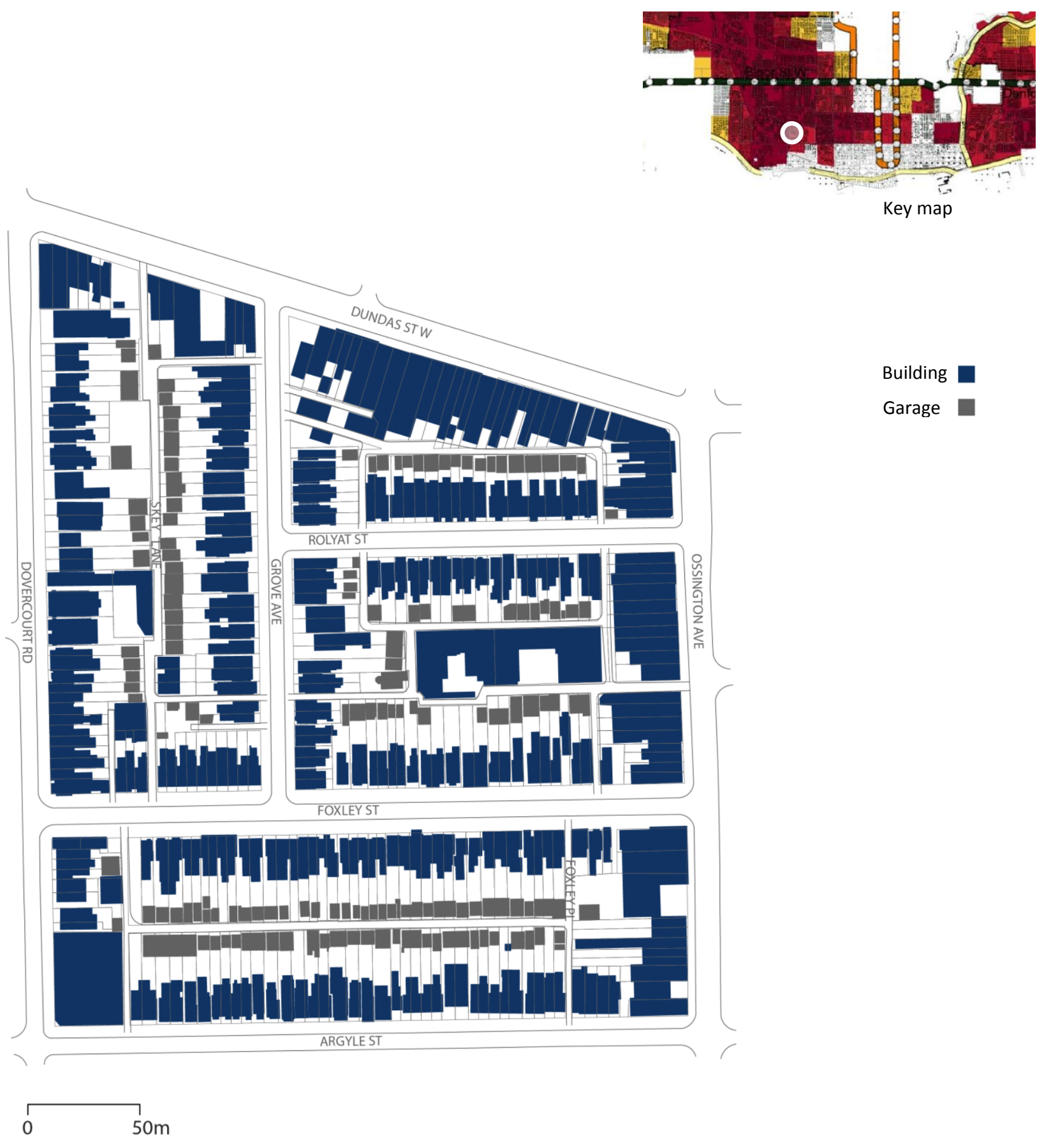

Figure 20: Potential test site 3 in Trinity Bellwood neighbourhood in Toronto (Image by author, 2014) Original map from: Ryerson University, 2014 
Figure 21: Potential test site 2 in Parkdale neighbourhood

in Toronto (Image by author, 2014)

Original map from: Ryerson University, 2014
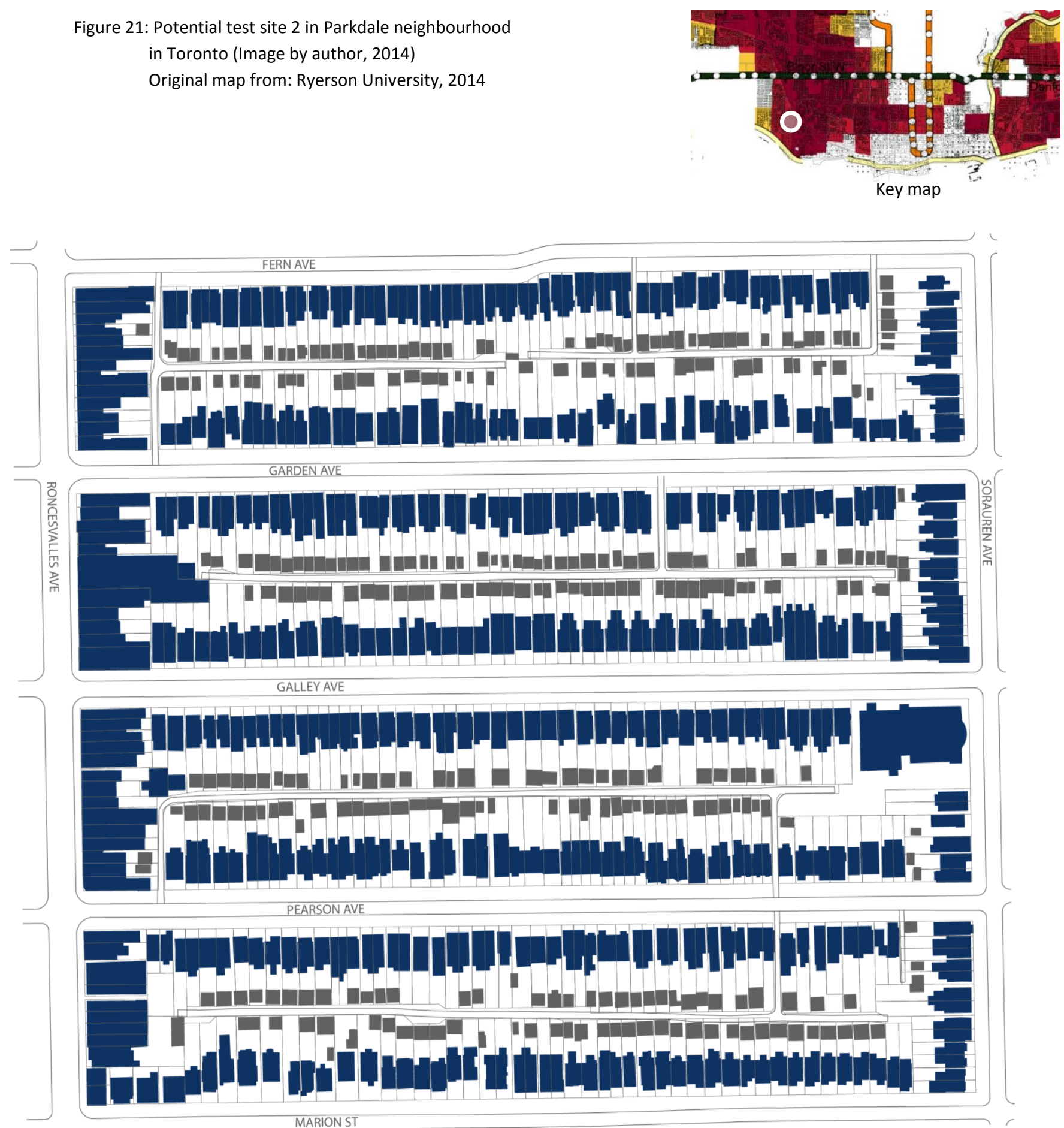

Building

Garage 


\section{5-3- Field Research}

\section{Test area: Physical Character and Actual Density}

Field research was conducted in the test area with two main objectives:

1- To estimate the actual number of dwelling units including informal housing units.

2- To develop an understanding of the physical character of the neighbourhood and of the possibilities for intensification within the physical character of the neighbourhood.

To achieve the above objectives a check list form was created to collect information about informal housing and also the physical character of the neighbourhood. The check list encompasses elements suggesting the existence of informal housing. These elements include the number of ring bells, mail boxes, hydro meters, the number of entrances and parking spaces, and the quantity of door numbers. By analyzing collected information and comparing data, the actual number of dwelling units was estimated. For instance the following observation suggests that there are extra units in a building:

A building has several mail boxes or several ring bells while having only one hydro meter. The single hydro meter indicates that Toronto Hydro does not recognize the units as legal.

A building has three mail boxes while having only one parking spot on the back lane. This is significant because one parking spot indicates that recognizes one dwelling unit as legal, given that according to the City of Toronto Zoning By-law the minimum parking requirement for residential buildings is one space per dwelling unit.

Although basement units can be legal secondary units, basement units with separate entrance were considered informal due to their potential for an informal extra unit.

The actual number of units might be higher than the estimated number in this study, as this paper did not include all types of informal housing due to the limited time and scope of study. For instance, shared rooms accommodating individual users is a type of informality not included in this research while this study assumes one household person per unit.

It is important to emphasize that there is a high level of uncertainty in identifying informal housing and calculating the actual number of dwelling units due to the lack of data resources such as Census of Canada and National Household Survey about informal housing units. As the nature of informal unit indicates to be hidden, owners and renters of these units tend to not share information about these units.

\section{5-4- Defining and Testing Scenarios}

In this step several scenarios for increasing density in the test area were defined and tested. This step addresses the question of how to increase density in stable neighbourhoods while maintaining neighbourhood character. This study refers to neighbourhood character as the prevailing physical form of a neighbourhood defined by the pattern of streets, blocks and lanes, lot size and shape, height and scale of buildings, and patterns 
of setbacks and landscaped open spaces. Various alternatives for increasing density were explored by defining scenarios. Similarly, three dimensional models of scenarios were created illustrating the impact of each scenario on the morphology of the neighbourhood not only in plan. Testing several variations to the existing density condition determines how Toronto's Zoning By-law can be more effective in stable neighbourhoods and also how adopting laneway housing development can increase housing choice in the core of the city.

These scenarios attempt to portray the actual implication of the existing Zoning By-law and also to demonstrate opportunities for residential intensification in keeping with neighbourhood character.

Each scenario presents:

- The number of dwelling units that can be added

- Those buildings have surpassed the zoning restrictions

- The increase in density to the study area. For the purpose of this study density is considered as the number of dwelling Units per Hectare (UPH). Floor Space Index (FSI) which is the ratio of built space area to property area is not employed as this study is focused on how many dwelling units can be added and UPH can indicate the number of dwelling units while FSI presents the area of space in comparison to property area.

Four groups of scenarios were defined; the first group of scenarios shows the current condition of the area including legal units and informal housing while other groups of scenarios illustrate the addition of secondary suites, laneway housing.

This study defines 12 scenarios of various density and built form. The following table is a summary of the defined scenarios. 
Table 2: Summary of the developed scenarios for increasing density while maintaining neighbourhood character

\begin{tabular}{|c|c|c|c|c|}
\hline \multicolumn{3}{|c|}{ Scenario } & \multirow{2}{*}{$\begin{array}{l}\text { The scenario applies to ... } \\
\text { all of the properties with } \\
\text { laneway access }\end{array}$} & \multirow{2}{*}{$\begin{array}{l}\text { It is anticipated that the } \\
\text { scenario will ... } \\
\text { illustrate existing } \\
\text { condition }\end{array}$} \\
\hline A-1 & & $\begin{array}{l}\text { Existing built form including } \\
\text { legal dwelling units (not } \\
\text { including informality) }\end{array}$ & & \\
\hline A-2 & & $\begin{array}{l}\text { Existing built form including } \\
\text { legal dwelling units and } \\
\text { informal units }\end{array}$ & $\begin{array}{l}\text { all of the properties with } \\
\text { laneway access }\end{array}$ & $\begin{array}{l}\text { illustrate existing } \\
\text { condition }\end{array}$ \\
\hline A-3 & & $\begin{array}{l}\text { Existing as of right defined by } \\
\text { the current Zoning By-law }\end{array}$ & $\begin{array}{l}\text { all of the properties with } \\
\text { laneway access }\end{array}$ & $\begin{array}{l}\text { illustrate existing } \\
\text { condition }\end{array}$ \\
\hline B-1 & \multirow{2}{*}{\multicolumn{2}{|c|}{$\begin{array}{l}\text { Addition of suites located above garages, with } \\
\text { height restriction of } 10 \text { metres, based on the } \\
\text { existing Zoning By-law }\end{array}$}} & $\begin{array}{l}\text { those properties that already } \\
\text { have a garage }\end{array}$ & $\begin{array}{l}\text { increase number of } \\
\text { dwelling units }\end{array}$ \\
\hline B-2 & & & $\begin{array}{l}\text { all of the properties with } \\
\text { laneway access }\end{array}$ & $\begin{array}{l}\text { increase number of } \\
\text { dwelling units }\end{array}$ \\
\hline C-1-1 & \multirow[t]{5}{*}{$\begin{array}{l}\text { Addition of } \\
\text { Laneway } \\
\text { houses, with } \\
\text { height } \\
\text { restriction of } 10 \\
m\end{array}$} & \multirow[t]{2}{*}{$\begin{array}{l}\text { Addition of } 1 \text { storey Laneway } \\
\text { housing based on the } \\
\text { "Laneway Housing How-To } \\
\text { Guide" created by the City of } \\
\text { Vancouver. }\end{array}$} & $\begin{array}{l}\text { Properties with minimum lot } \\
\text { width of } 7.3 \mathrm{~m} \text {, and minimum } \\
\text { side yard setback of } 0.6 \mathrm{~m} \text { for } \\
\text { the existing building, dictated } \\
\text { by Vancouver laneway } \\
\text { housing guideline }\end{array}$ & $\begin{array}{l}\text { increase number of } \\
\text { dwelling units }\end{array}$ \\
\hline$C-1-2$ & & & $\begin{array}{l}\text { properties with minimum lot } \\
\text { width of } 7.3 \mathrm{~m} \text {, dictated by } \\
\text { Vancouver laneway housing } \\
\text { guideline }\end{array}$ & $\begin{array}{l}\text { increase number of } \\
\text { dwelling units }\end{array}$ \\
\hline$C-2-1$ & & \multirow[t]{2}{*}{$\begin{array}{l}\text { Addition of } 1.5 \text { storey } \\
\text { Laneway housing based on } \\
\text { Vancouver guideline }\end{array}$} & $\begin{array}{l}\text { Properties with minimum lot } \\
\text { width of } 7.3 \mathrm{~m} \text {, and minimum } \\
\text { side yard setback of } 0.9 \mathrm{~m} \text { for } \\
\text { the existing building, dictated } \\
\text { by Vancouver laneway } \\
\text { housing guideline }\end{array}$ & $\begin{array}{l}\text { increase number of } \\
\text { dwelling units }\end{array}$ \\
\hline$C-2-2$ & & & $\begin{array}{l}\text { properties with minimum lot } \\
\text { width of } 7.3 \mathrm{~m} \text {, dictated by } \\
\text { Vancouver laneway housing } \\
\text { guideline }\end{array}$ & $\begin{array}{l}\text { increase number of } \\
\text { dwelling units }\end{array}$ \\
\hline$C-3$ & & $\begin{array}{l}\text { Addition of } 3 \text { storey Laneway } \\
\text { housing based on Stinson- } \\
\text { Van Elsander model for slot } \\
\text { lots }\end{array}$ & $\begin{array}{l}\text { all of the properties with } \\
\text { laneway access }\end{array}$ & $\begin{array}{l}\text { increase number of } \\
\text { dwelling units }\end{array}$ \\
\hline D-1 & \multirow{2}{*}{$\begin{array}{l}\text { Addition of } \\
\text { laneway } \\
\text { developments } \\
\text { while } \\
\text { maintaining } \\
\text { physical } \\
\text { character } \\
\text { beyond current } \\
\text { Zoning By-law }\end{array}$} & $\begin{array}{l}\text { Addition of laneway housing } \\
\text { with maximum } 4 \text { storey }\end{array}$ & $\begin{array}{l}\text { all of the properties with } \\
\text { laneway access }\end{array}$ & $\begin{array}{l}\text { increase number of } \\
\text { dwelling units } \\
\text { change neighbourhood } \\
\text { character }\end{array}$ \\
\hline D-2 & & $\begin{array}{l}\text { Addition of laneway housing } \\
\text { with maximum } 6 \text { storey }\end{array}$ & $\begin{array}{l}\text { all of the properties with } \\
\text { laneway access }\end{array}$ & $\begin{array}{l}\text { increase number of } \\
\text { dwelling units } \\
\text { change neighbourhood } \\
\text { character }\end{array}$ \\
\hline
\end{tabular}




\section{Scenario A: Existing Condition Governed by the Zoning By-law}

Scenario $A$ is defined to illustrate the existing condition of the area according to the existing built form and also current Zoning By-law density and height requirement. Three scenarios of various densities were defined under Scenario A. Scenario A-1 presents existing buildings and legal dwelling units in the area and does not include noticed informal units while Scenario A-2 illustrates existing buildings including noticed informal units. Scenario A3 demonstrates how the area would look like if all properties were built based on the existing as of right defined by the current Toronto's Zoning By-law.

Scenario A-1: Existing built form including legal dwelling units (not including informality)

1. Applies to all of the properties

2. Demonstrates the existing legal dwelling units based on the zoning by law

Scenario A-2: Existing built form including legal dwelling units and informal units

1. Applies to all of the properties

2. Demonstrates the legal existing dwelling units and noticed informality

SCENARIO A-3: Existing as of right

1. Applies to all properties

2. Maintains the existing zoning requirements including (Zoning By-law 569-2013):

- Maximum Floor Space Index (FSI) of 0.6 meaning the ratio of total floor area to lot area should be 0.6 or less;

- Maximum height of 10 metres;

- Minimum lot width of 3.5 metres (Zoning By-law 569-2013, 10.5.30.20);

- Minimum front yard setback of 6 metres (Zoning By-law 569-2013, 15.10.40.70 (1));

- Minimum back yard setback of 7.5 metres (Zoning By-law 569-2013, 15.10.40.70. (2);

- Minimum setback from a lane is 2.5 metres from the centerline of a lane. (Zoning By-law 5692013, 10.5.40.70 ZBL);

- There is no requirement for lot coverage and number of dwelling units in the study area.

(Zoning By-law 569-2013, 15.10.30.40. and 15.10.40.1);

- Maximum number of secondary suites in a detached or semi-detached house is one (Zoning Bylaw 569-2013, 150.10.20.1 (2));

- Minimum interior floor area for a dwelling unit is 55 square metres (Zoning By-law 569-2013, 150.10.40.40. (2)); 
- Minimum interior floor area for a secondary unit is 55 square metres (Zoning By-law 569-2013, 150.10.40.40. (2));

- There is no parking requirement for a secondary unit (Zoning By-law 569-2013, 150.10.80.1).

Scenario B: Addition of suites located above garages, with height restriction of 10 metres, based on the existing Zoning By-law

As some properties in the area have a detached garage on laneway and some do not have a garage, two scenarios were defined under Scenario B. In Scenario B-1 a suite was added only above the existing garages, while Scenario B-2 assumes that all properties have a detached garage and a suite above.

\section{Scenario B-1:}

1. Applies to those properties that already have a garage

2. Based on existing built form including legal dwelling units and informal units (Scenario A-2)

3. Addition of a suite located above existing garage

\section{Scenario B-2:}

1. Applies to all of the properties with laneway access

2. Based on existing built form including legal dwelling units and informal units (Scenario A-2)

3. Addition of a suite located above garage

\section{Scenario C: Addition of laneway houses, with height restriction of 10 metres}

Based on the height requirements in the existing Zoning By-law, this group of scenarios limits the height of new buildings to 10 metres and is based on two models of laneway housing in Vancouver and Toronto. Scenario C1 employs laneway housing guideline created by the City of Vancouver as a detailed how-to guide for laneway housing. Scenario C-2 uses a laneway housing prototype suggested for Toronto based on the "Study of Laneway Housing in Toronto" by Jeffrey Stinson and Terrance Van Elsander Architects.

For laneway housing developments the City Vancouver designed the "Laneway Housing How-To Guide". This guideline demonstrates a set of requirements for one storey and one and half storey laneway housing developments. Also it considers lot width and side yard setback as two factors to determine if a property is eligible for having laneway housing or not. Based on the number of storeys scenario C-1 and C-2 were defined and under each two scenarios were created based on lot width and side yard setback requirements. Scenario C-1 and C-2 presents that if Vancouver guidelines were adapted and applied into the test area how much density would be added and how the morphology would have been changed. 
Scenario C-1: Addition of 1 storey Laneway housing based on the "Laneway Housing How-To Guide" created by the City of Vancouver.

This scenario is defined to illustrate how the test area would have been changed if the Vancouver guideline for one storey laneway housing was implemented in the area.

The Vancouver guideline indicates the requirements for lot width, building height, setbacks, unit size and parking. Also the guideline defines specific requirements for building depth, open space area, and side yard setback to maintain shadowing and fire access considerations. This determines which house can or cannot have laneway houses.

According to Vancouver "Laneway Housing How-To Guide" (2013), the requirements for one storey laneway housing include:

- Minimum open space of $4.9 \mathrm{~m}$ between existing building and laneway house

- Maximum building depth of $9.8 \mathrm{~m}$

- Maximum unit size of 900 sqf without regard to lot size

- Minimum unit size of 16- 19 sqm

- Maximum height of $3.7 \mathrm{~m}$ for flat roof and of $4.6 \mathrm{~m}$ for pitched roof

- Minimum parking requirement of one space with $9 \mathrm{ft} 6$ inch width

The above requirements are applicable to scenario C-1-1 and C-1-2.

\section{Scenario C-1-1:}

In this scenario a one storey laneway house is added to those properties meet the minimum requirements for side yard setback and lot width. Scenario C-1-1 highlights how many properties have the potential for the addition of laneway house considering the side yard setback of existing buildings. This scenario illustrates how the addition of one storey laneway houses based on Vancouver guideline would impact the morphology of the area.

1. Based on the actual existing condition noticed informality (Scenario A-2)

2. Applies to properties with laneway access and with

- Minimum lot size of $7.3 \mathrm{~m}$, and

- Minimum side yard setback of $0.9 \mathrm{~m}$ for the existing building for fire access from main street (City of Vancouver, 2013).

\section{Scenario C-1-2:}

Scenario C-1-2 and Scenario C-1-1 are similar in that both of them illustrate what could be possible if Vancouver model for one storey laneway housing was implemented in the study area. The difference between Scenario C-1-1 and C-1-2 is that Scenario C-1-2 applies to all properties with minimum lot width of 7.3 metres and 
does not utilizes the side yard setback requirements, assuming that existing houses were replaced by new buildings with minimum side yard setback of 0.9 metre or fire access would be provided from laneways.

1. Based on actual existing condition noticed informality (Scenario A-2)

2. Applies to properties with minimum lot size of $7.3 \mathrm{~m}$ (City of Vancouver, 2013).

Scenario C-2: Addition of 1.5 storey Laneway housing based on Vancouver guideline.

This scenario illustrates how the morphology and density of the test area would have been changed if 1.5 storey laneway houses were added to the area according to the Vanouver laneway housing guideline. Two scenarios are defined under Scenario C-2 with various requirements for side yard setback of principal buildings.

According to Vancouver design guideline, the requirements for one storey laneway housing include (City of Vancouver, 2013):

- Minimum open space of $4.9 \mathrm{~m}$ between existing building and laneway house

- Maximum building depth of $7.9 \mathrm{~m}$

- Maximum unit size of 900 sqf without regard to lot size

- Minimum unit size of 26-19 sqm

- Maximum area of upper floor is $60 \%$ of ground floor area

- Maximum height of $5.5 \mathrm{~m}$ for flat roof and of $6.1 \mathrm{~m}$ for pitched roof

- Minimum parking requirement of one space with $9 \mathrm{ft} 6$ inch width

The above requirements applied to Scenario C-2-1 and C-2-2.

Scenario C-2-1:

Scenario C-2-1 presents the addition of 1.5 storey laneway houses on properties those meet the minimum requirements for lot size and side yard setback. This scenario illustrates the morphology and density of the area if 1.5 store laneway houses were added to properties those their existing condition meet the minimum requirements for side yard setback.

1. Based on actual existing condition noticed informality (Scenario A-2)

2. Applies to properties with laneway access and with

- Minimum lot size of $7.3 \mathrm{~m}$, and

- Minimum side yard setback of $0.9 \mathrm{~m}$ for the existing building for fire access from main street (City of Vancouver, 2013). 


\section{Scenario C-2-2:}

Similar to Scenario C-2-2, this scenario illustrates the change in the morphology and density of the test area due to the addition of 1.5 storey laneway housing based on Vancouver guideline. However, Scenario C-2-2 does not utilize the minimum requirement for side yard setback of principal building.

1. Based on actual existing condition noticed informality (Scenario A-2)

2. Applies to properties with minimum lot size of $7.3 \mathrm{~m}$ (City of Vancouver, 2013).

Scenario C-3: Addition of 3 storey Laneway housing based on Stinson- Van Elsander model for slot lots Jeffery Stinson and Terrance Van Elsander created a typology for residential laneway developments in Toronto. The typology was mainly based on lot shape (Stinson and Van, 2003). Considering the lot shapes in the study area, this scenario implements Stinson-Van Elsander model for slot lot prototype. Slot lot is described as a small lot that is only accessible from the lane. A design prototype was proposed for slot lots. This prototype applied to lots with average width of 5 metres with an average existing back yard of 14.5 metres (Stinson and Van, 2003). To calculate the number of additional dwelling units on a property this study assumes that:

- The minimum area of a dwelling unit is 26 square metres.

- The minimum area is defined based on the Vancouver laneway housing guideline. According to the City of Vancouver the minimum area of a laneway house is 26 square metres (City of Vancouver, 2013) while Toronto's Zoning By-law determines the minimum area of 55 square metres for a dwelling unit (Zoning Bylaw 569-2013).

- The laneway house will provide parking space for the main house. The average parking area is considered 20 square metres.

- Efficiency ratio is $80 \%$. Efficiency ratio is the proportion of rentable area to gross area of a building.

For example, a 3 storey laneway house is built on a property with one original legal house. If the gross area of the new development is 160 square metres, it means that the rentable area is 128 square metres (150x80\%). Providing one parking spot on the ground floor will decrease the area of the ground floor to 100 square metres, indicating that ground floor can have four 26 sqm units while the upper storeys can have five units, and in total 14 units can be added.

Scenario C-3:

1. Based on actual existing condition noticed informality (Scenario A-2)

2. Applies to properties with average back yard depth of $14.5 \mathrm{~m}$ and minimum width of $5 \mathrm{~m}$. All properties in the study area meet this criterion.

3. Laneway house requirements:

- Minimum open space of $6 \mathrm{~m}$ between existing building and laneway house

- With balcony and roof garden 
- Maintains parking for the existing house (Stinson and Van, 2003).

\section{Scenario D: Laneway developments while maintaining physical character beyond current Zoning By-law}

1. Applies to all properties with laneway access

2. Based on actual existing condition noticed informality (Scenario A-2)

3. Addition of laneway houses. The height of laneway developments should not be visible from front streets. This would be established as the only zoning restriction.

Two scenarios with various maximum heights are defined under Scenario D. According to the Ontario Building Code buildings higher than four storeys should have elevator and also should be constructed with steel structure instead of wood structure. As the requirement of steel structure as well as the addition of elevator will increase the cost and as a result will decrease the affordability of laneway houses, Scenario D-1 and D-2 are defined.

Scenario D-1: allowing laneway developments with maximum 6 storey

Scenario D-2: allowing laneway developments with maximum 4 storey

To calculate the number of additional dwelling units on a property, Scenario D-1 and D-2 make the same assumptions as Scenario C-3:

- The minimum area of a dwelling unit is 26 square metres.

- The laneway house will provide parking space for the main house. The average parking area is considered

20 square metres.

- Efficiency ratio is $80 \%$.

This scenario is an exploratory attempt to understand what could have happened if there was not any zoning restriction beyond height, dictated by what is visible from the street. The cornerstone criterion for this scenario is to ensure that new laneway developments will respect and retain the physical character of the neighbourhood. To identify the maximum height of laneway developments that will maintain the neighbourhood character the visual cone of a pedestrian on sidewalks was defined indicating the zone that can be seen. If the laneway development is within the hatched area it will not be visible from the front street and will not affect the perceived character of the neighbourhood.

The next section presents the results of spatial analysis of low and middle income areas in proximity to transit and laneway structure. Also, the increased density and impact on neighbourhood character in each scenario is discussed and a comparative analysis is provided.

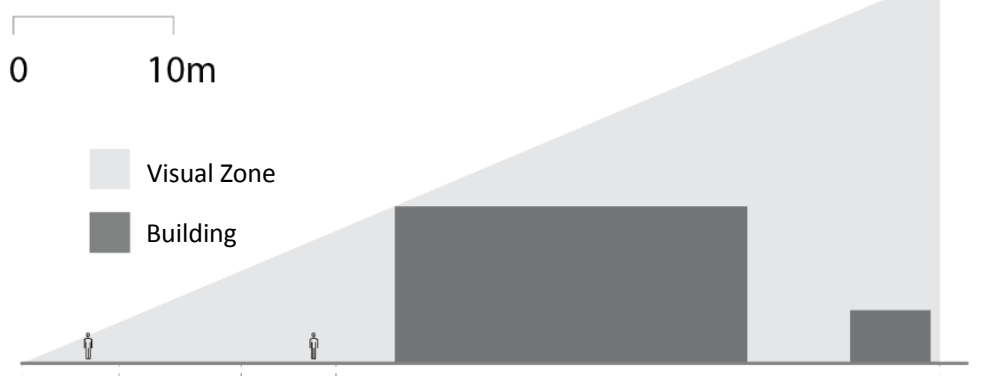

Figure 22: Schematic section illustrating pedestrian visual zone from street (Image by author, 2014) (Human figure from Noun Project website) 


\section{6- Results}

This section highlights the results from the methods in three sections:

- Results from spatial analysis and mapping

- Result from field research

- Result from tested scenarios

The result of the spatial analysis of the middle and low income areas of Toronto is illustrated as the cost of housing in areas near to transit networks is rising and middle and low income households face affordability problems. Similarly, the results of field research addressing existing informality and the physical character of neighbourhood in the study area are reviewed. In addition this section presents the results of testing various scenarios for increasing the number of dwelling units in the study area while maintaining its physical character.

\section{6-1- Results from Spatial Analysis and Mapping}

According to the Three Cities within Toronto, a research by David Hulchanski (2010), middle and low income areas in the inner city are being replaced by high income areas. However there are some areas in the core of the city that accommodate low and middle income households. These areas have the potential to be transformed to high income neighbourhoods due to the proximity to transit and given the trend of gentrification that Hulchanski has highlighted. These areas can be gradually gentrified and become less affordable as they have been since 1970 across the city. The following schematic map (Figure 23) shows the middle and low income areas under the threat of complete gentrification.

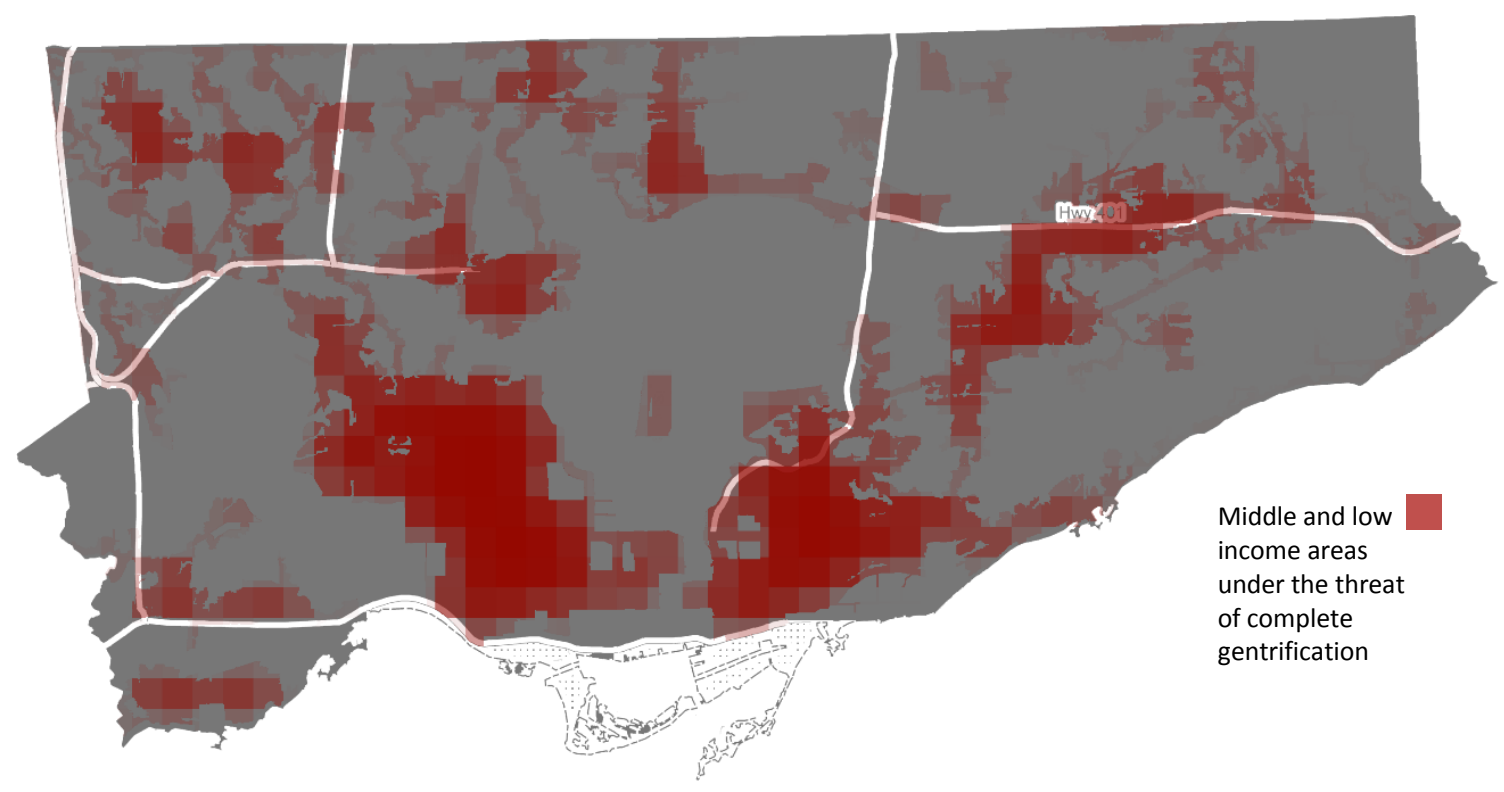

Figure 23: Schematic map illustrating the middle and low income areas under the threat of complete gentrification (Hulchanski, 2010, edited by author, 2014) 
Given the value of laneways as a hidden urban asset with the potential to accommodate extra density, the addition of small units on laneways provides an affordable housing choice for sole individuals and lone parents to live in the core. The following map (Figure 23) represents potential areas for incremental intensification and laneway developments. Utilizing Hulchanski's income maps, the City of Toronto Walkability map and the GIS maps of Toronto, the Figure 24 highlights those low and middle income areas in proximity to transit networks and laneway structure.

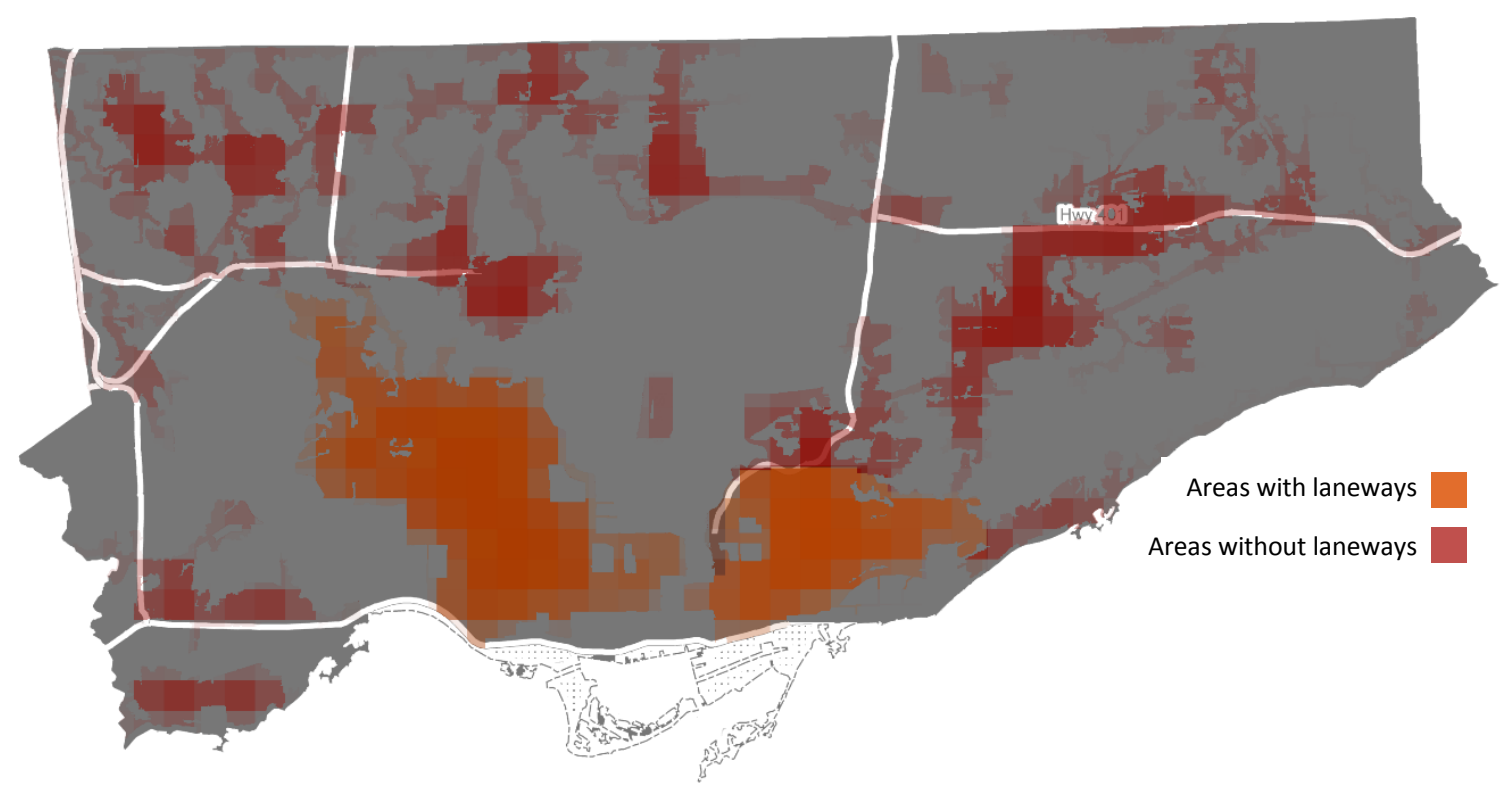

Figure 24: Schematic map illustrating the middle and low income areas near to laneway structure and under the threat of complete gentrification (City of Toronto, 2012 and Hulchanski, 2010, edited by author, 2014)

\section{6-2- Results from Field Research}

The field research was conducted to estimate the actual number of dwelling units in the test area. The following tables present the results of field observation:

An initial observation was conducted in three areas in Toronto located in Palmerston, Trinity Bellwood and Parkdale neighbourhood in order to select a site to test scenarios of different logics and levels of laneway housing implementation of what could be possible. Among the three sites, the area located in Palmerston was selected as test area. The selected test area was indicative of the existence of informal housing in the area suggesting a high demand for increasing housing choice.

Field research was conducted in the test area. The following tables outline the informality in the area using the number of entrances, door numbers, ring bells, mail boxes, hydro meters, suites located above garages and basement units with separate entrance. 

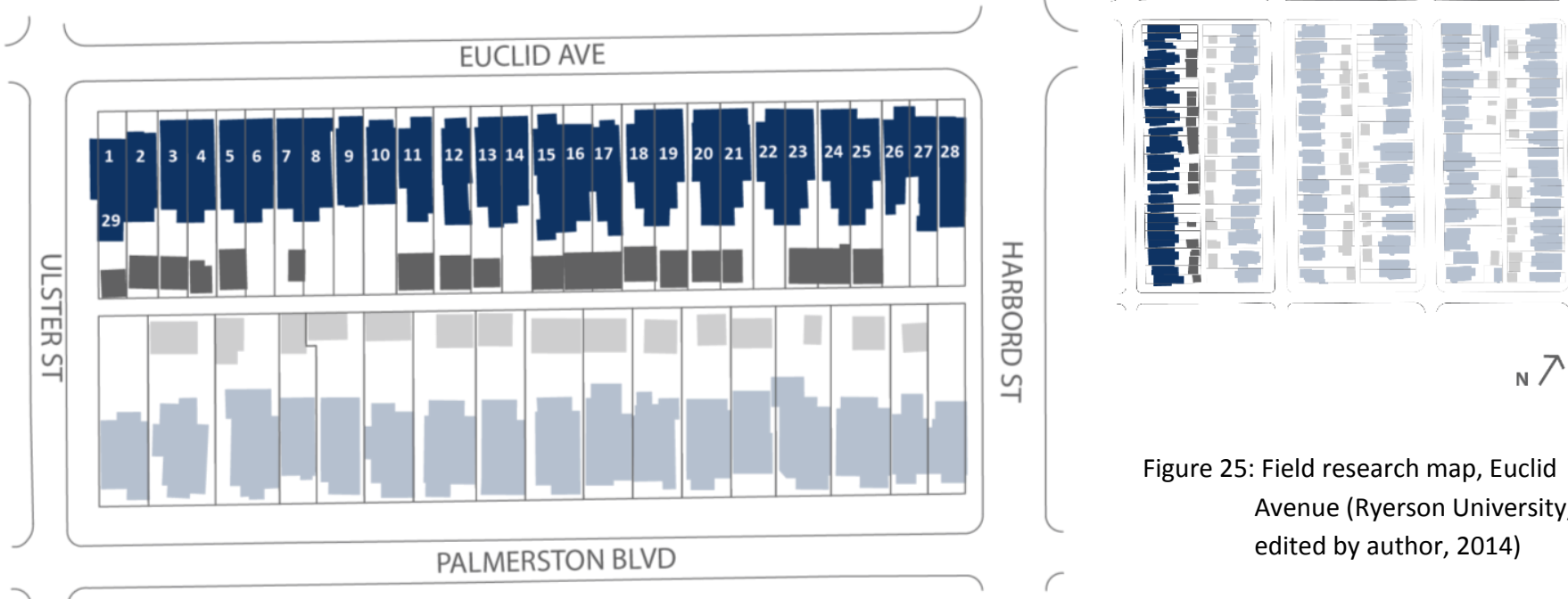

N

Figure 25: Field research map, Euclid Avenue (Ryerson University, edited by author, 2014)

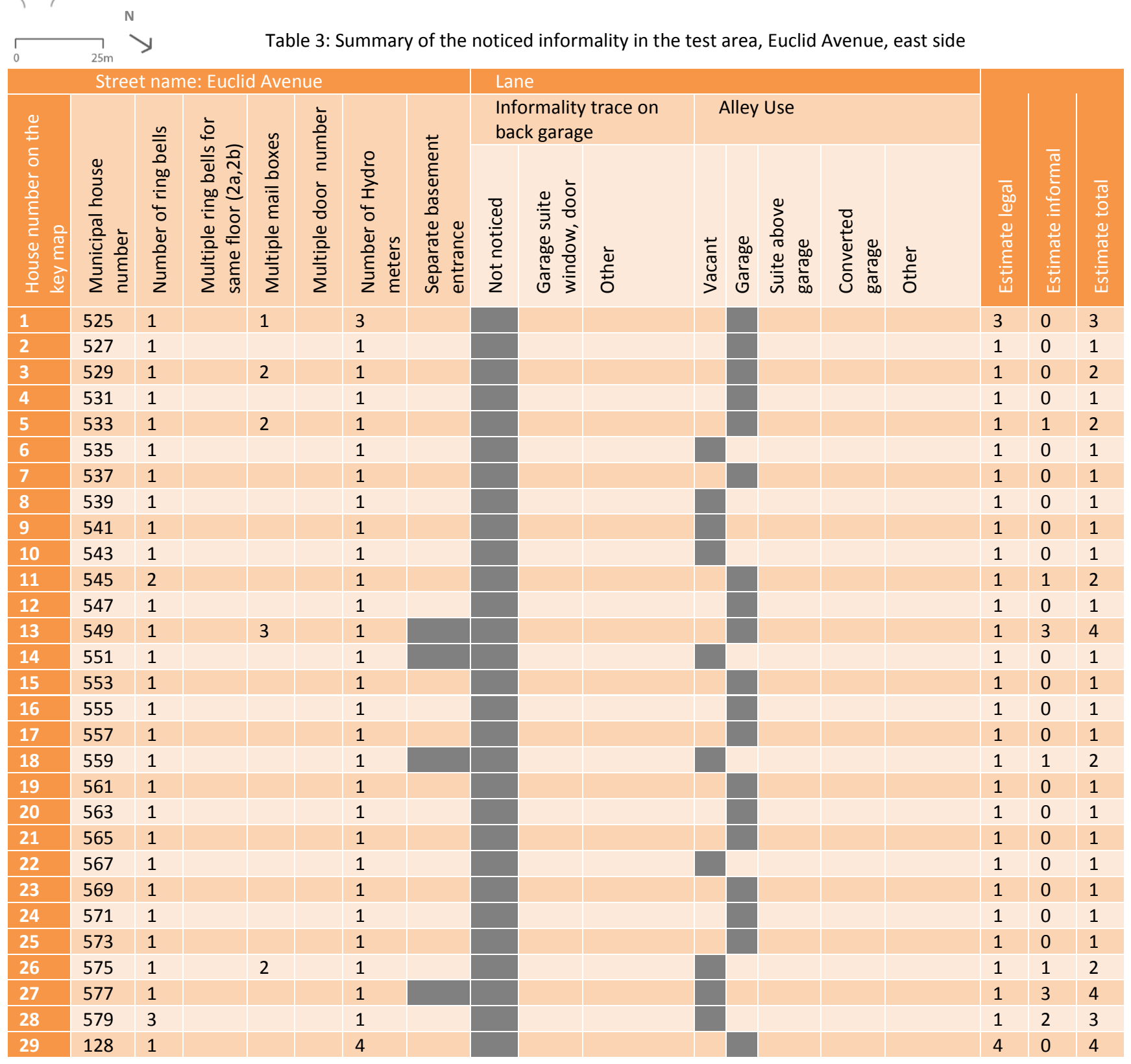



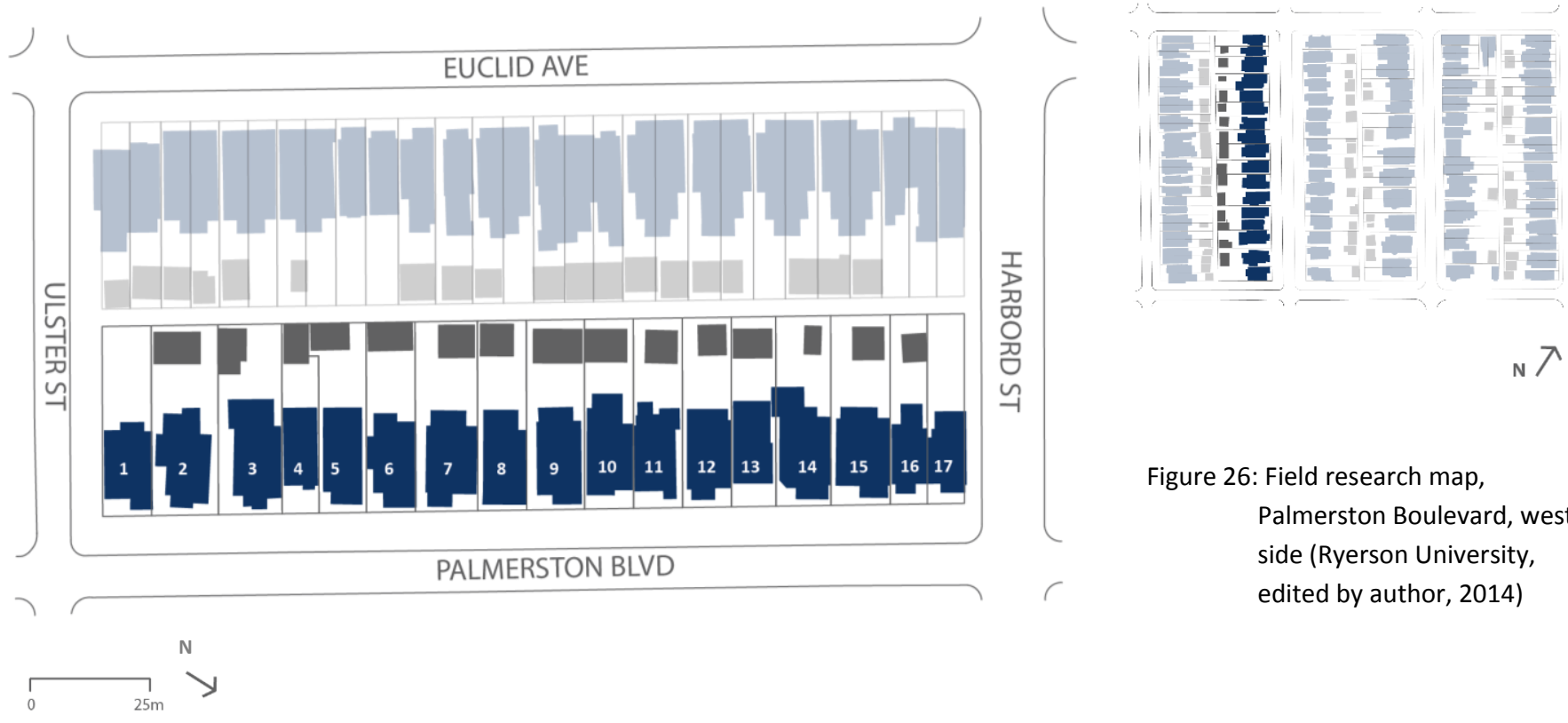

Figure 26: Field research map,

Palmerston Boulevard, west side (Ryerson University, edited by author, 2014)

Table 4: Summary of the noticed informality in the test area, Palmerston Boulevard, west side

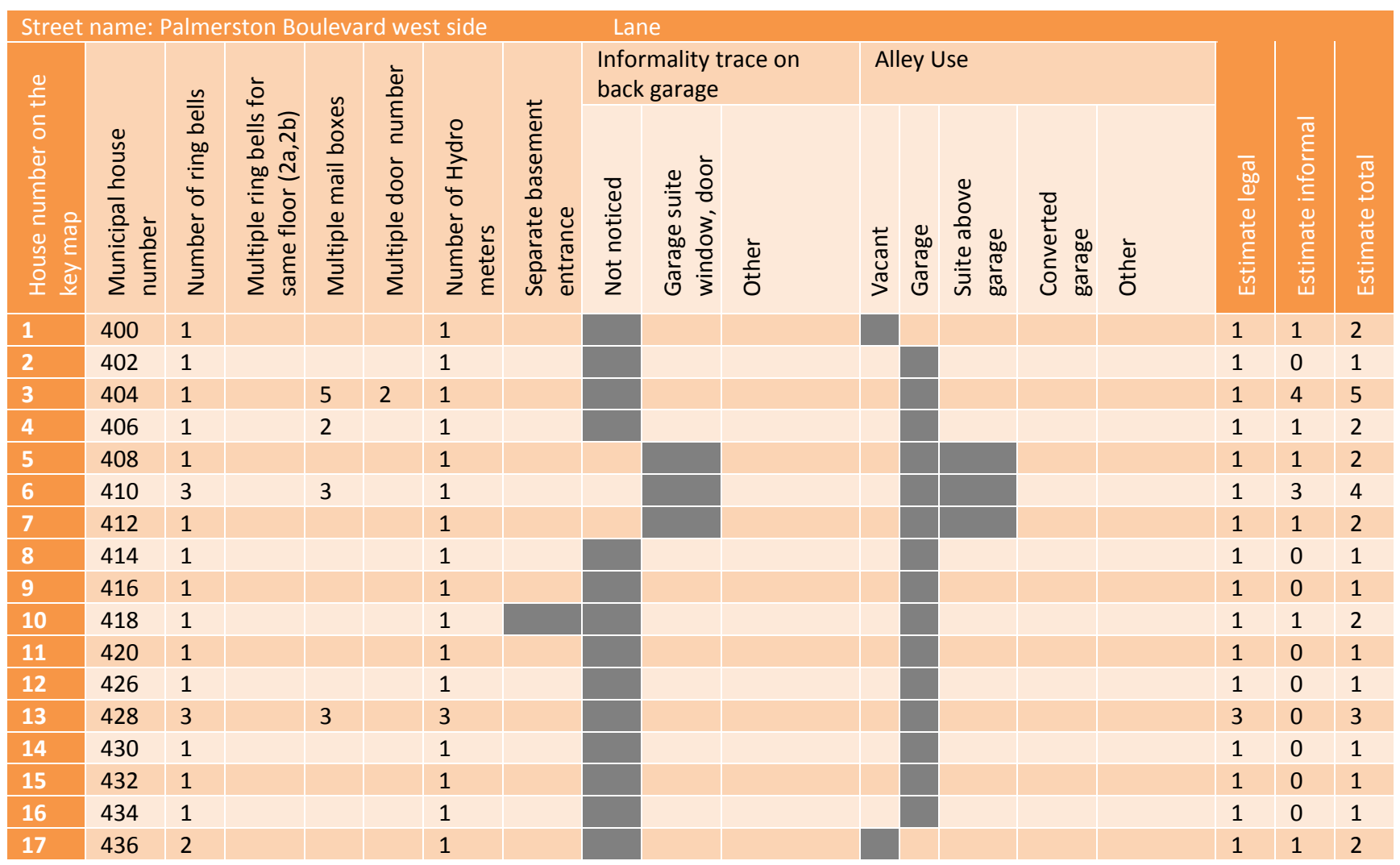



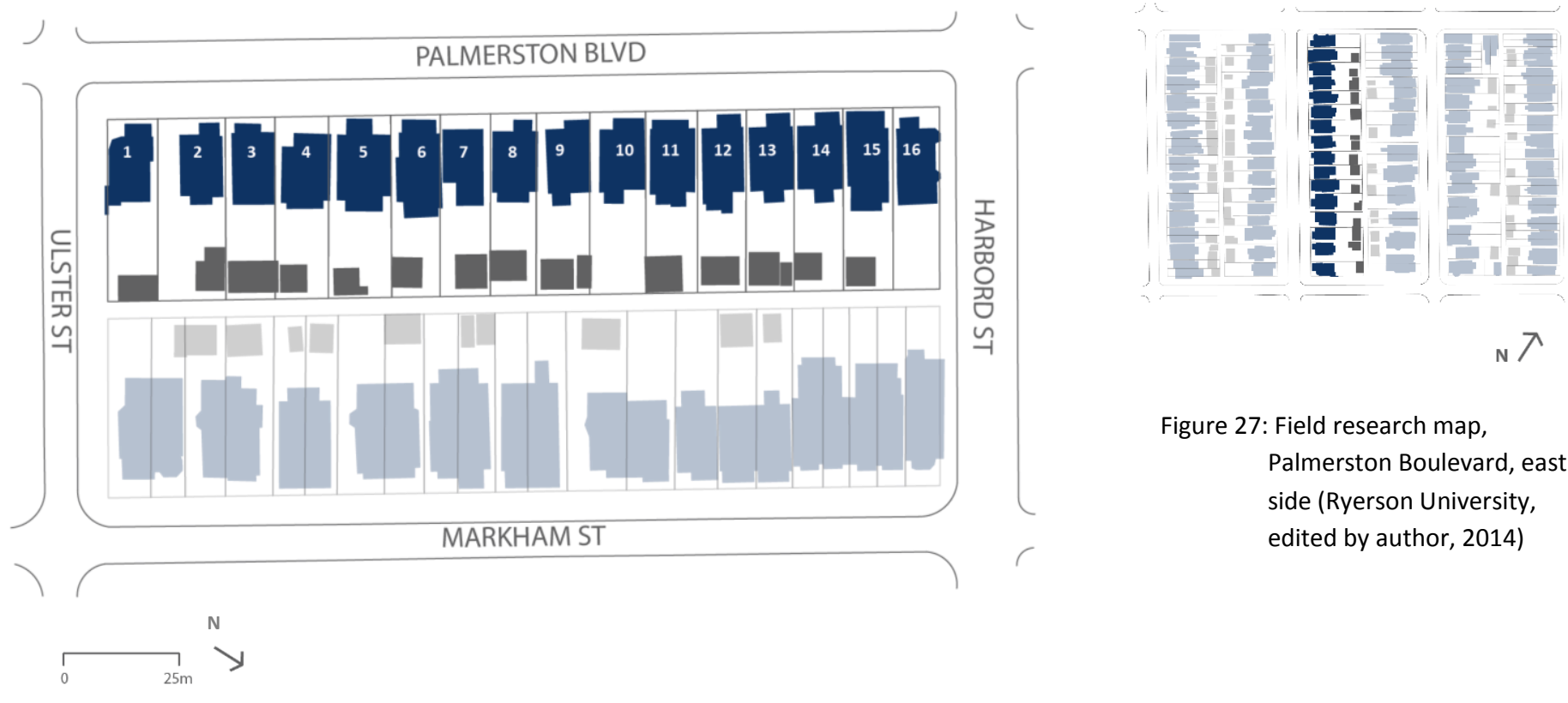

Figure 27: Field research map,

Palmerston Boulevard, east side (Ryerson University, edited by author, 2014)

Table 5: Summary of the noticed informality in the test area, Palmerston Boulevard, east side

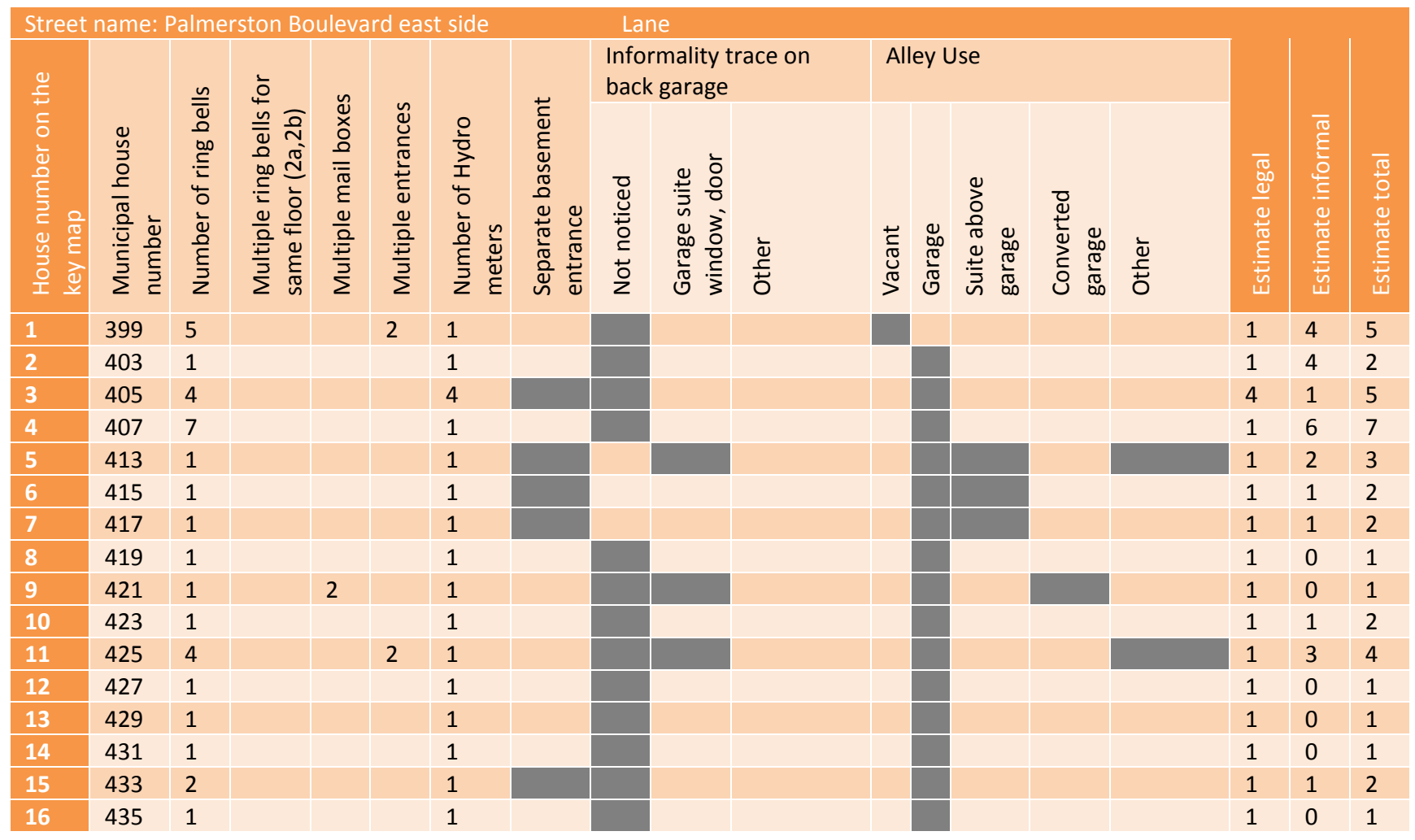



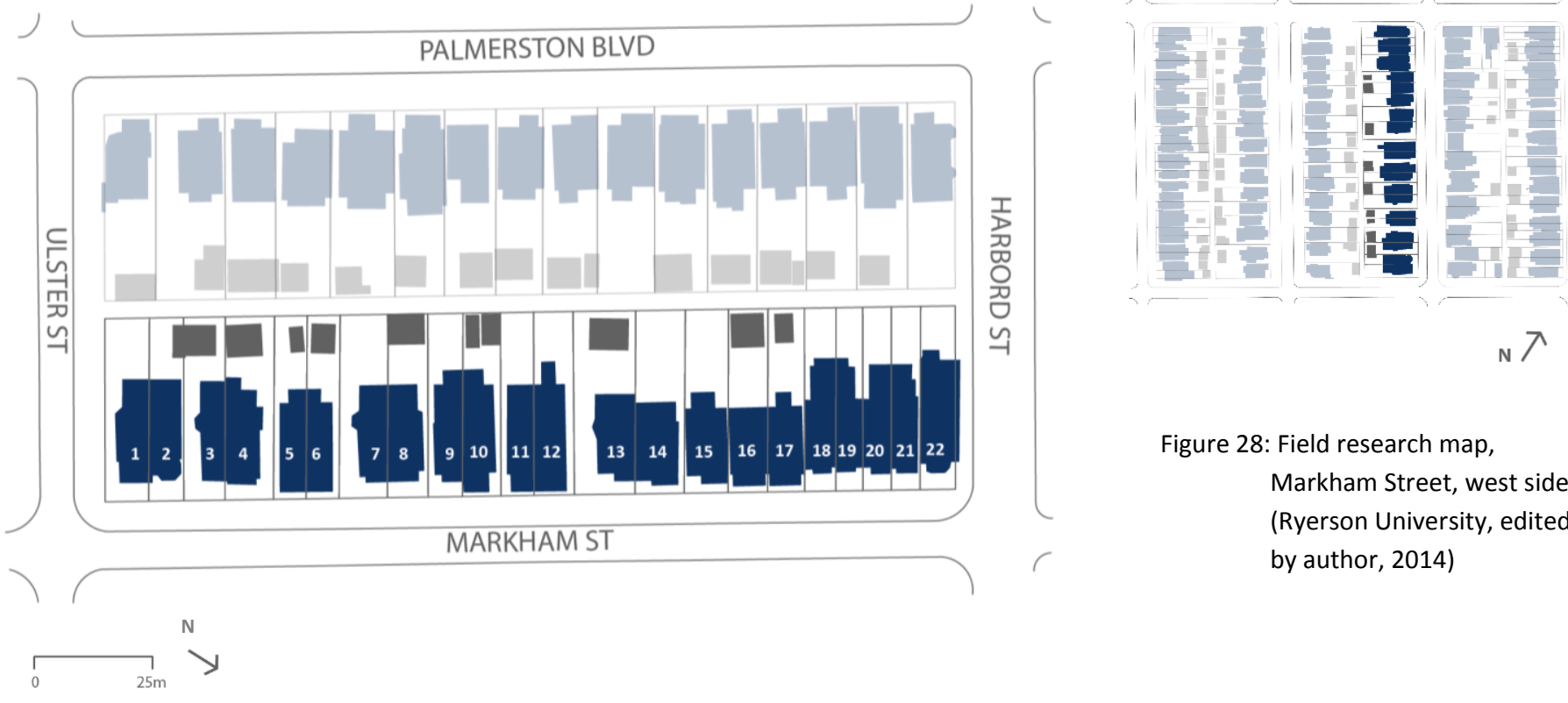

Figure 28: Field research map,

Markham Street, west side (Ryerson University, edited by author, 2014)

Table 6: Summary of the noticed informality in the test area, Markham Street, west side

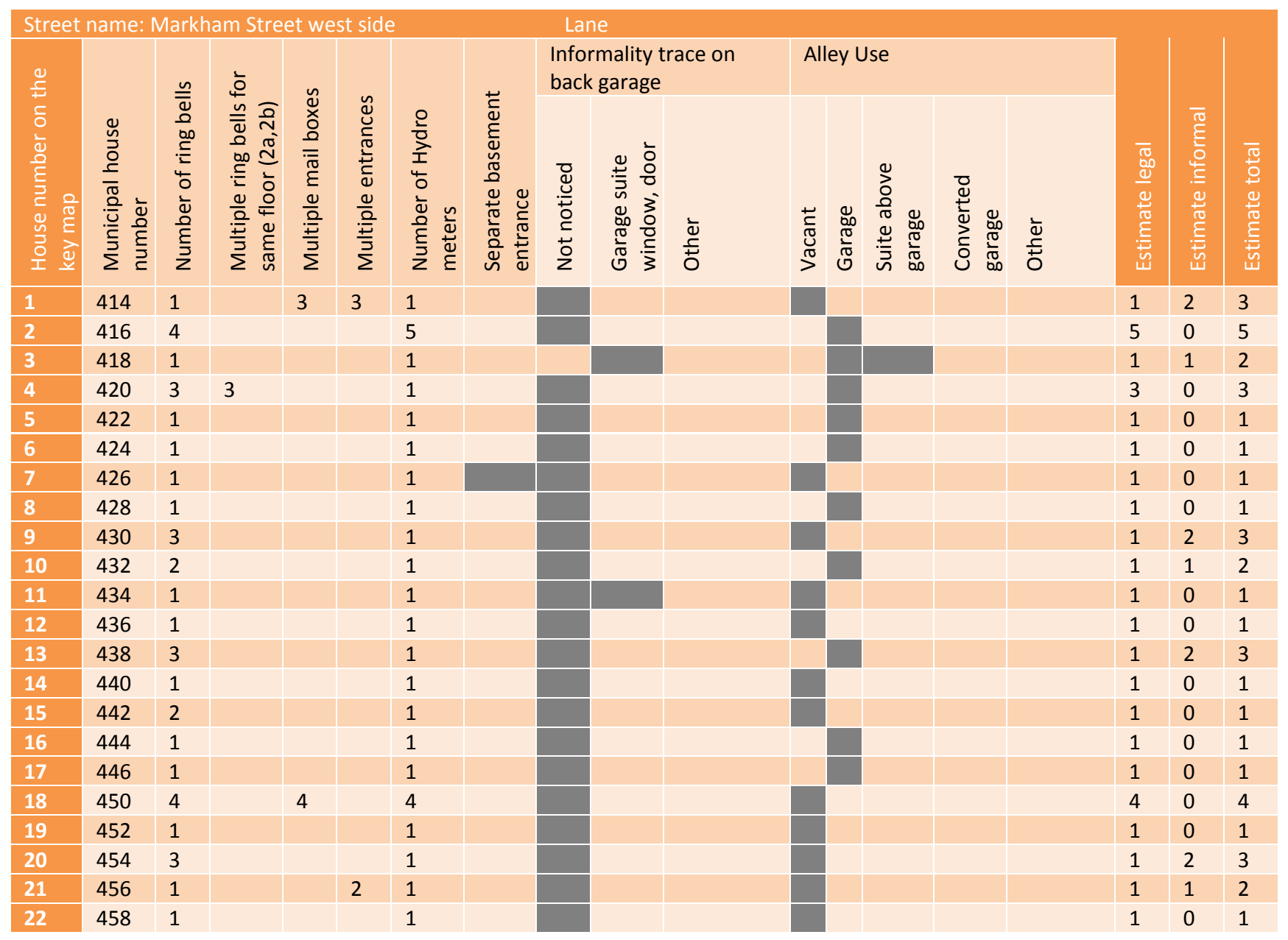




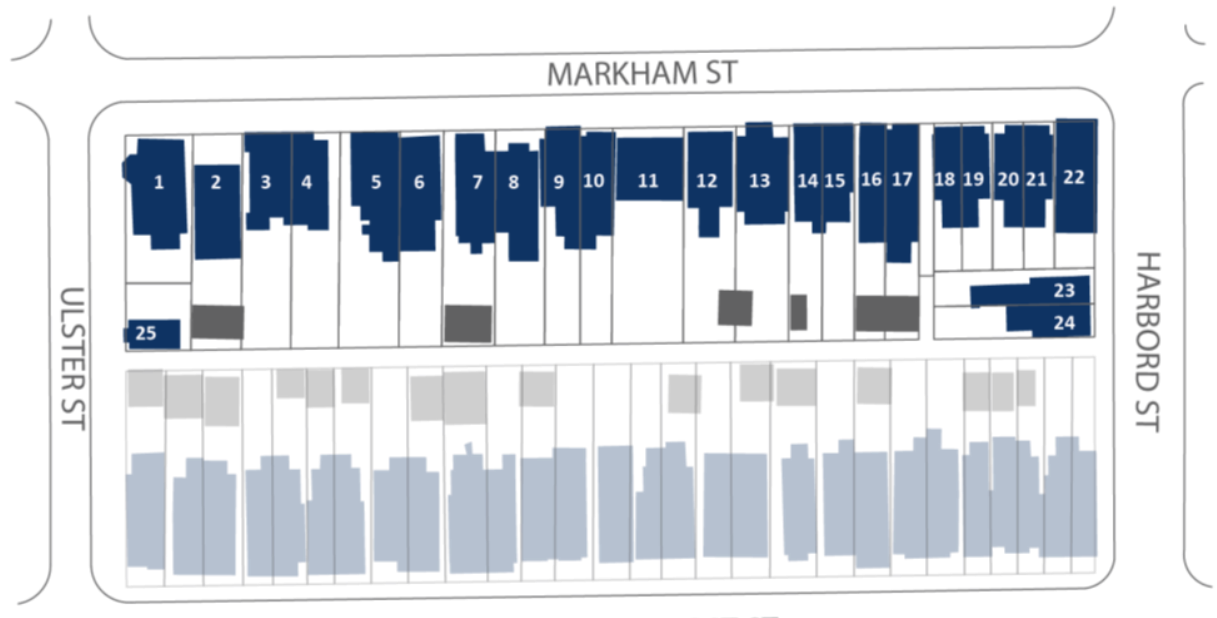

BATHURST ST

Table 7: Summary of the noticed informality in the test area, Markham Street, east side

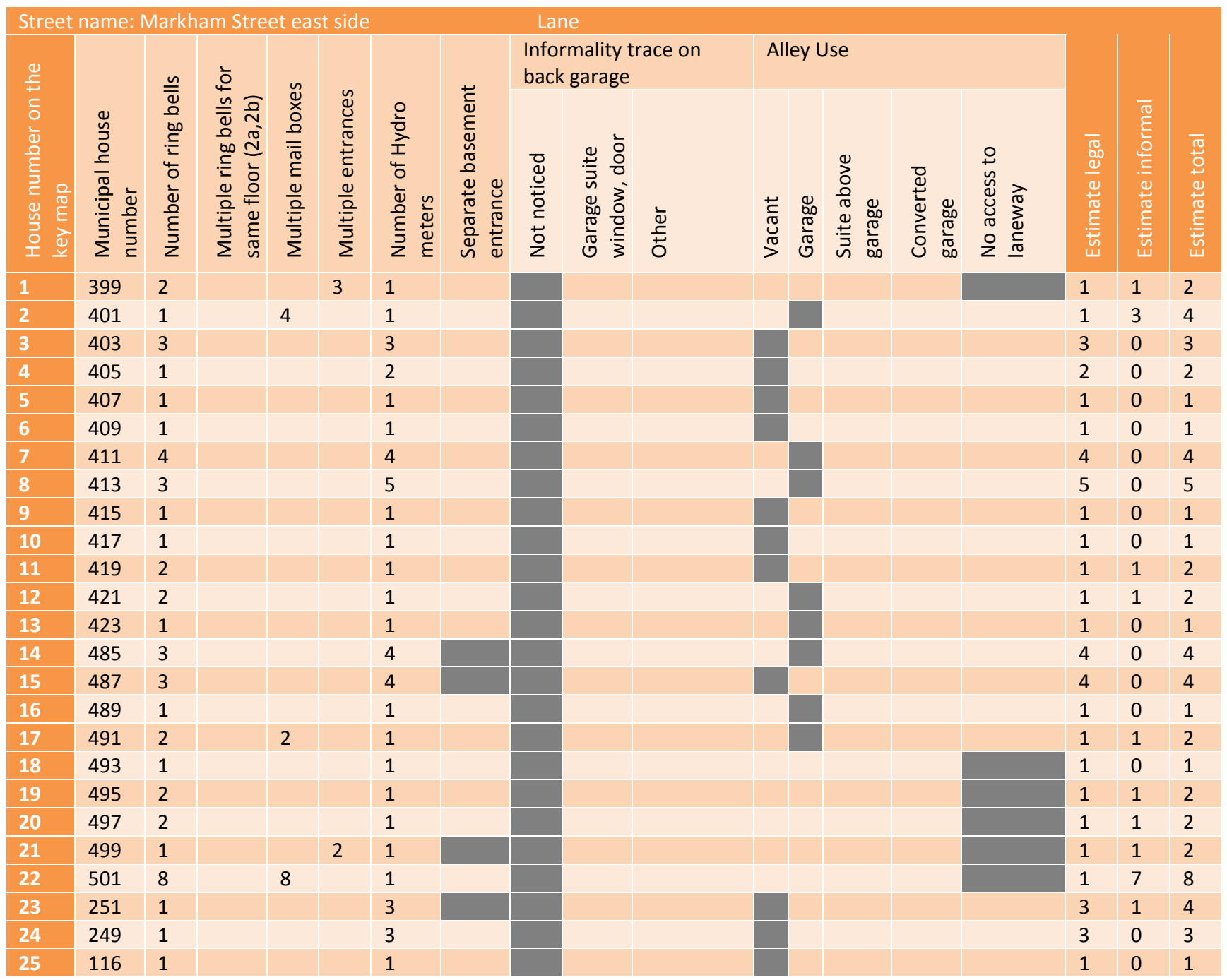

Markham Street, east side (Ryerson University, edited by author, 2014)

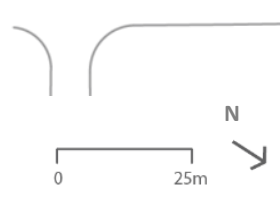

Figure 29: Field research map,

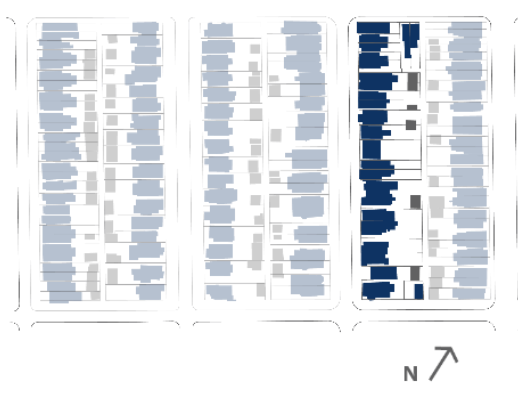



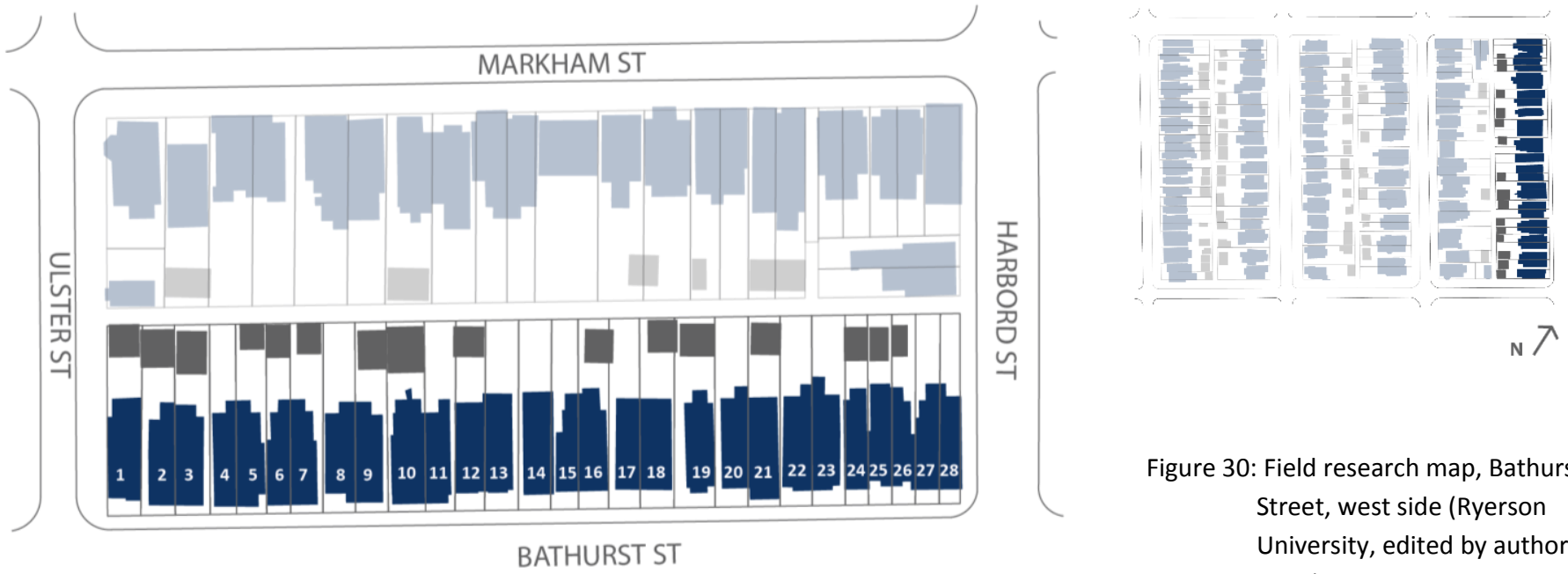

Figure 30: Field research map, Bathurst Street, west side (Ryerson University, edited by author, 2014)

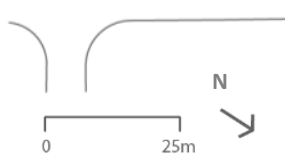

Table 8: Summary of the noticed informality in the test area, Bathurst Street, west side

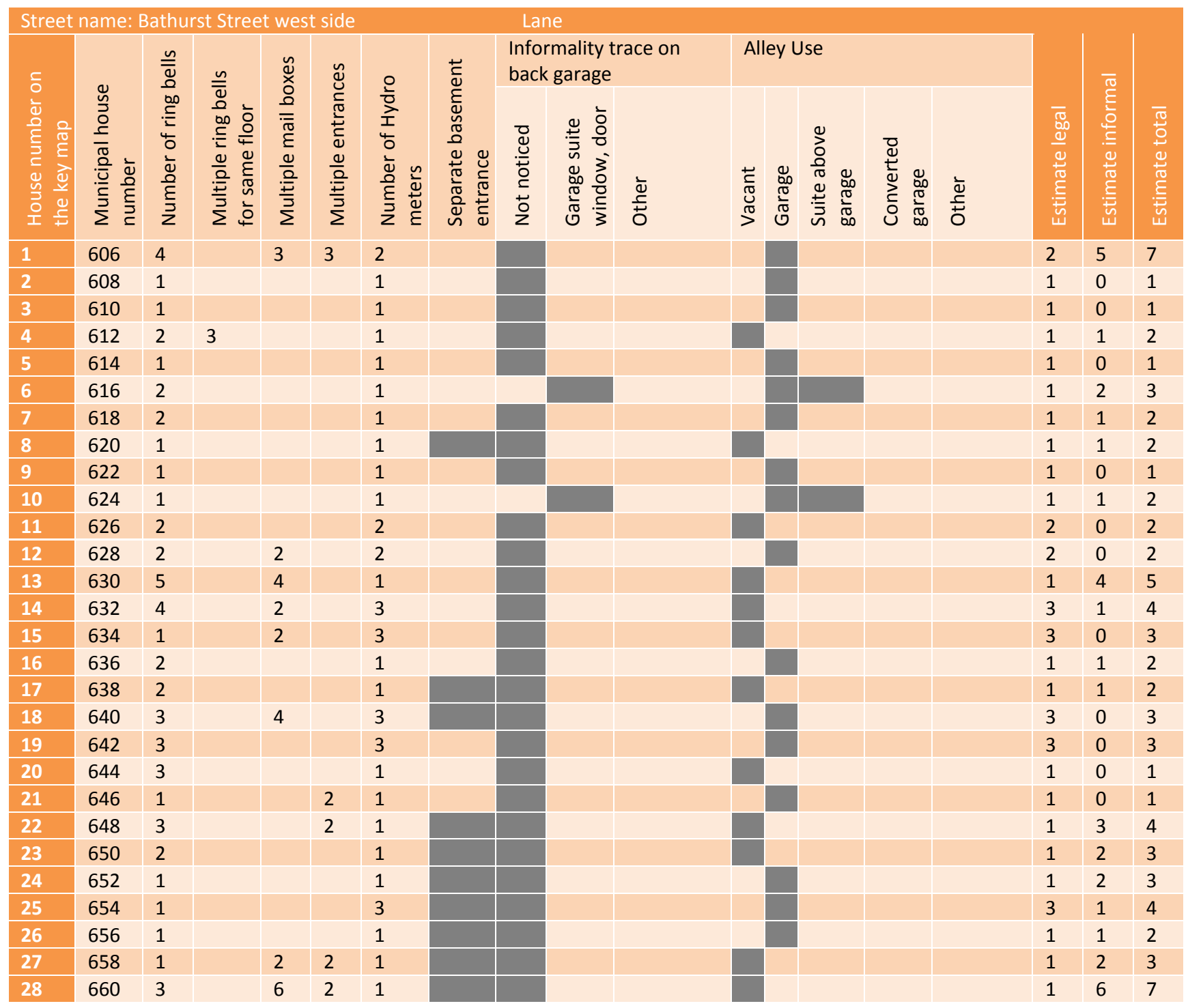


It was observed that 59 properties in the test area have informal units, including 9 properties with a suite located above garage and 25 properties have basement with separate entrance.

The prevalent building type in the test area is three storey semi-detached houses with the proximate height of 10 metres. All of the properties in the area have access to laneway except 6 properties on the east side of Markham Street. The area has narrow long lots, and lots along Palmerston Boulevard are wider than the other lots in the area. All of the buildings have front setback with landscaped area separating the property from the public street. The main feature in laneways area detached parking structures.
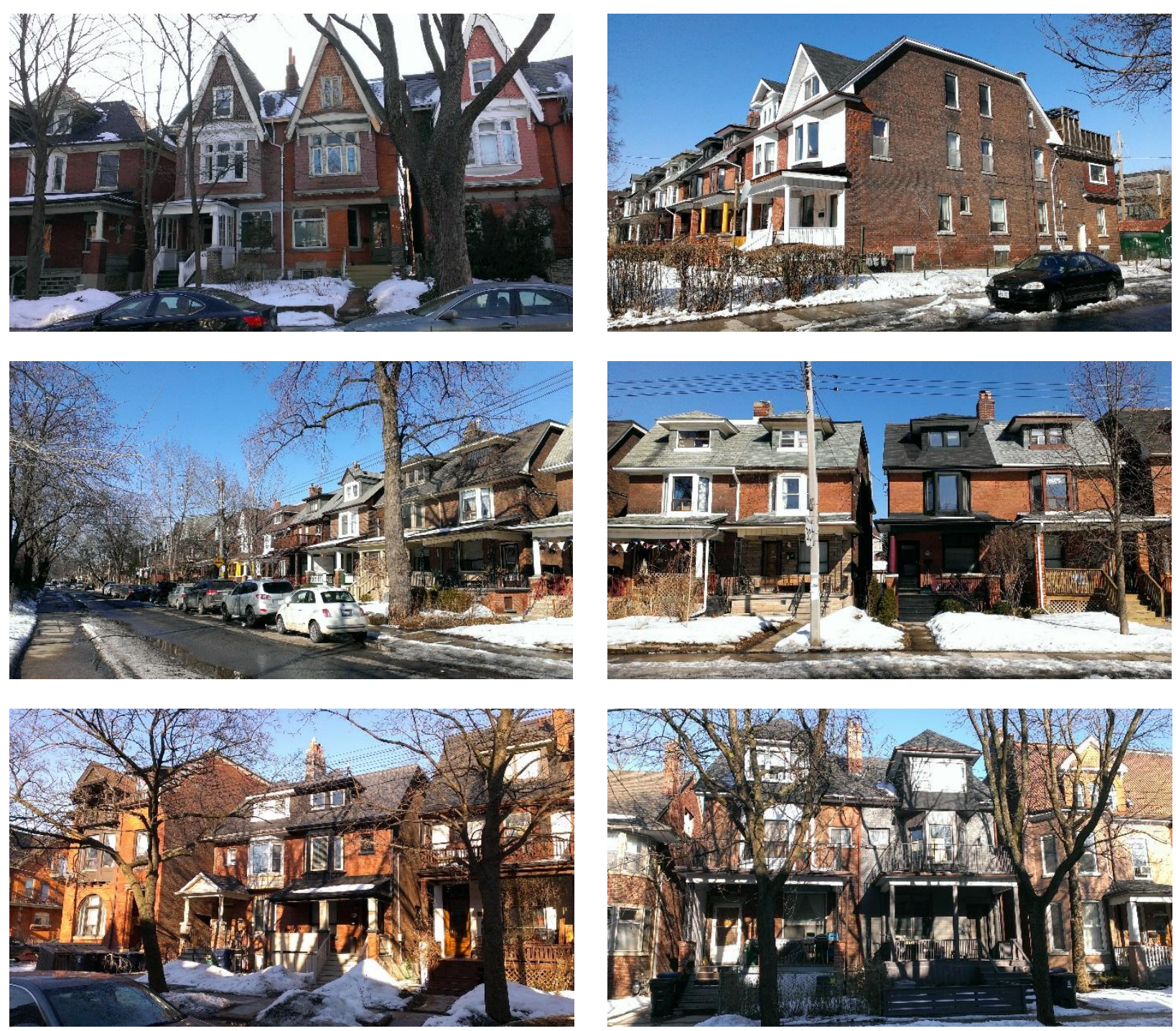

Figure 31, 32, 33, 34, 35 and 36: The street character of the study area in Palmerston in Toronto (Images by author, 2014) 

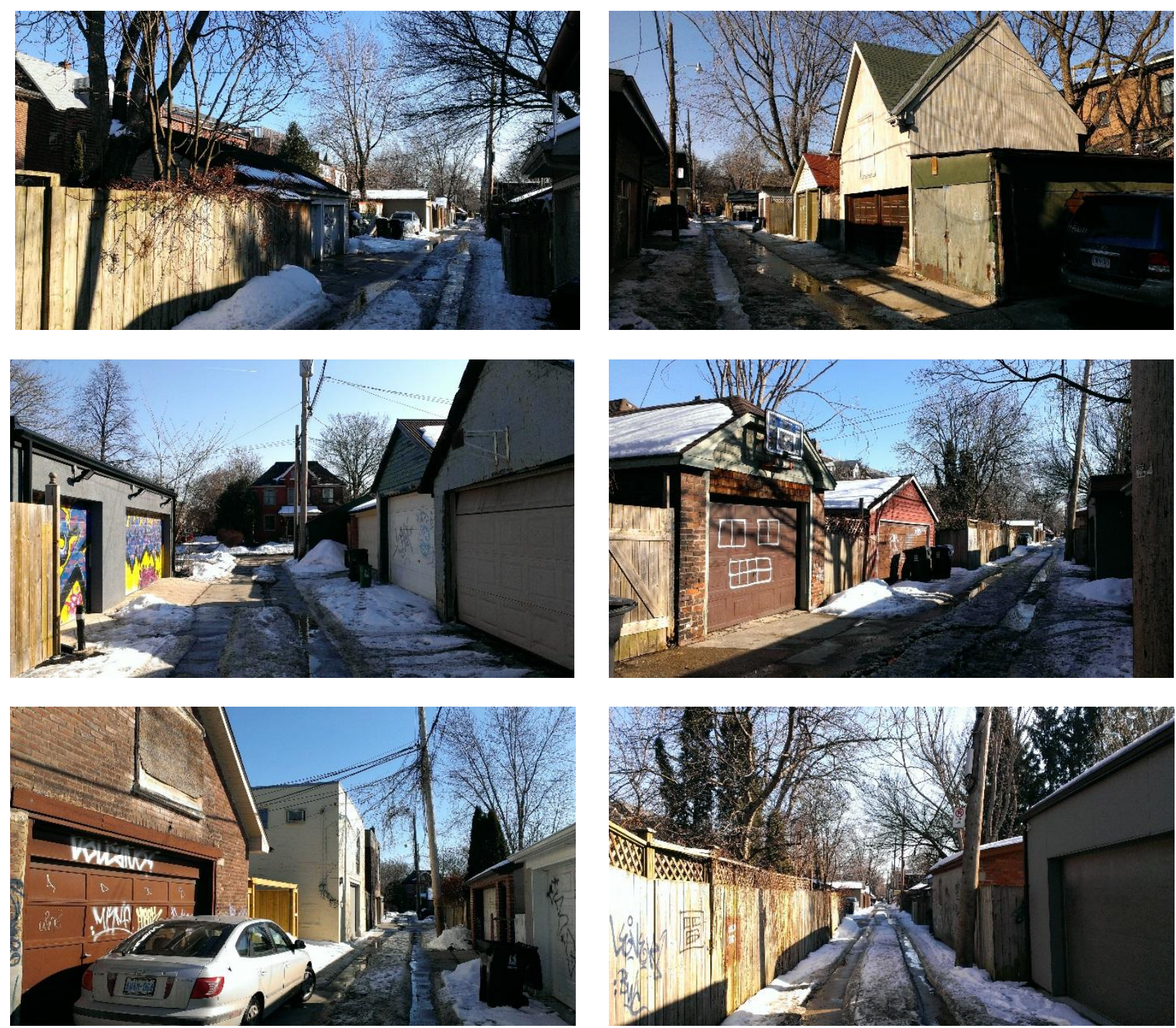

Figure 37, 38, 39, 40, 41 and 42: The laneway character of the study area in Palmerston in Toronto (Images by author, 2014)

\section{6-3- Results from Tested Scenarios}

The neighbourhood was then investigated through three dimensional analysis of the form to determine how to implement laneway housing while in keeping with the character of the neighbourhood as defined in this study.

Each scenario represents different practices of laneway housing implementation. It was anticipated that the addition of laneway housing would increase density while maintaining the character of the neighbourhood. 
Number of dwelling units per property
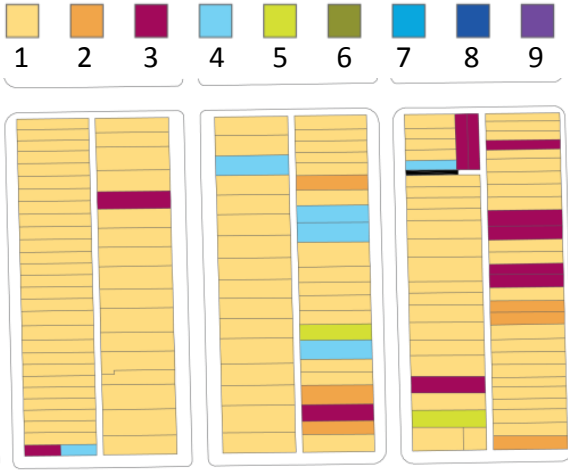

Figure 43: Plan diagram for Scenario A-1 presenting the number of dwelling units on each property in the test area in Palmerston in Toronto (Images by author, 2014)

1. Applies to all of the properties

2. Demonstrates the existing built form including legal dwelling units.

\section{Density Number of (units/ha): Units:}

34.7 191

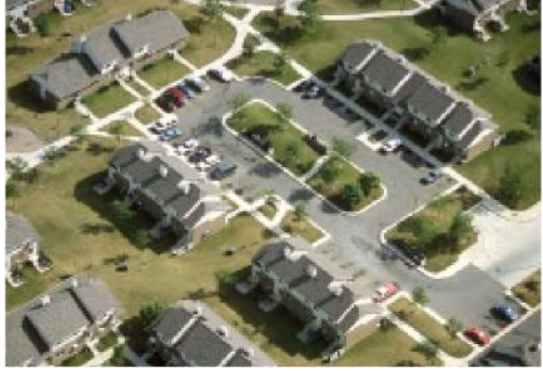

Figure 45: Detroit, MI with similar density as Scenario A-1 (Campoli and MacLean, 2007)

\section{Scenario A: Existing Condition Governed by the Zoning By-law}

Scenario A-1: $\quad$ Existing built form including legal dwelling units (not including informality)

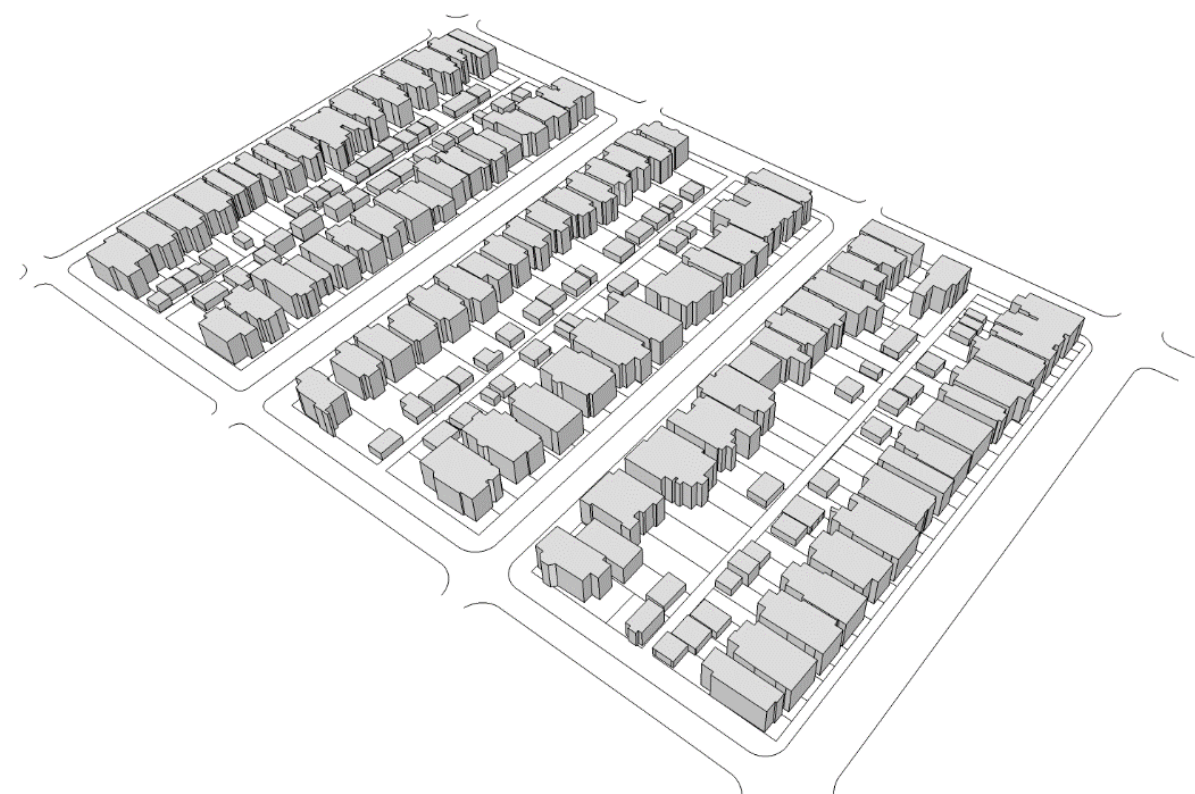

Figure 44: 3D model of Scenario A-1 depicting the Existing built form in the test area in Palmerston in Toronto (Images by author, 2014)

Scenario A-1 illustrates the existing built form of the selected test area based on the field observation. Semi-detached building with approximate height of 10 metres is the prevalent buildings form in the area.

In this scenario the number of legal units on a property is calculated based on the number of parking spots and hydro meters. For example single hydro meter and single parking spot indicates that only one unit is recognized legal by Toronto Hydro and City of Toronto. It appears that the $82 \%$ of the properties including 112 properties have only one legal unit. The total number of legal units seems to be 191 units indicating a density of 34.7 units per hectare.

Comparing the large size of the properties in this area and the legal density indicates that the area is underused in terms of density, given the proximity of the area to transit and being in high demand. 
Number of dwelling units per property

$$
\begin{array}{lllllllll}
1 & 2 & 3 & 4 & 5 & 6 & 7 & 8 & 9
\end{array}
$$
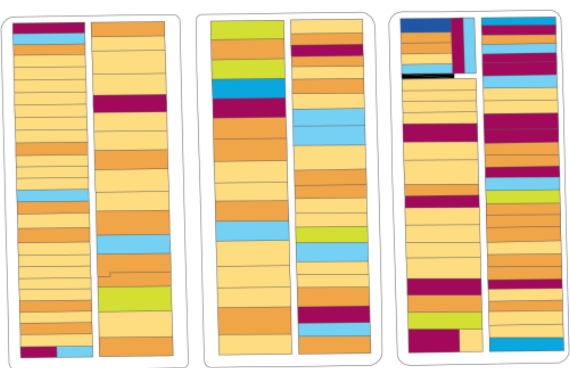

Figure 46: Plan diagram for Scenario A-2 presenting the number of dwelling units on each property in the test area in Palmerston in Toronto (Images by author, 2014)

1. Applies to all of the properties

2. Demonstrates the legal existing dwelling units and noticed informality

\section{Density (units/ha): \\ Number of}

54.7 301

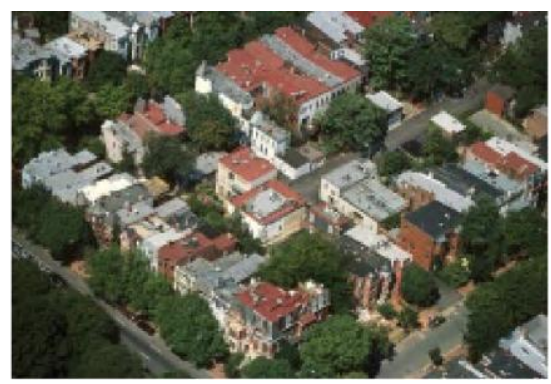

Figure 48: Washington, DC with similar density as Scenario A-2 (Campoli and MacLean, 2007)

\section{Scenario A: Existing Condition Governed by the Zoning By-law}

Scenario A-2: Existing built form including legal dwelling units and informal units

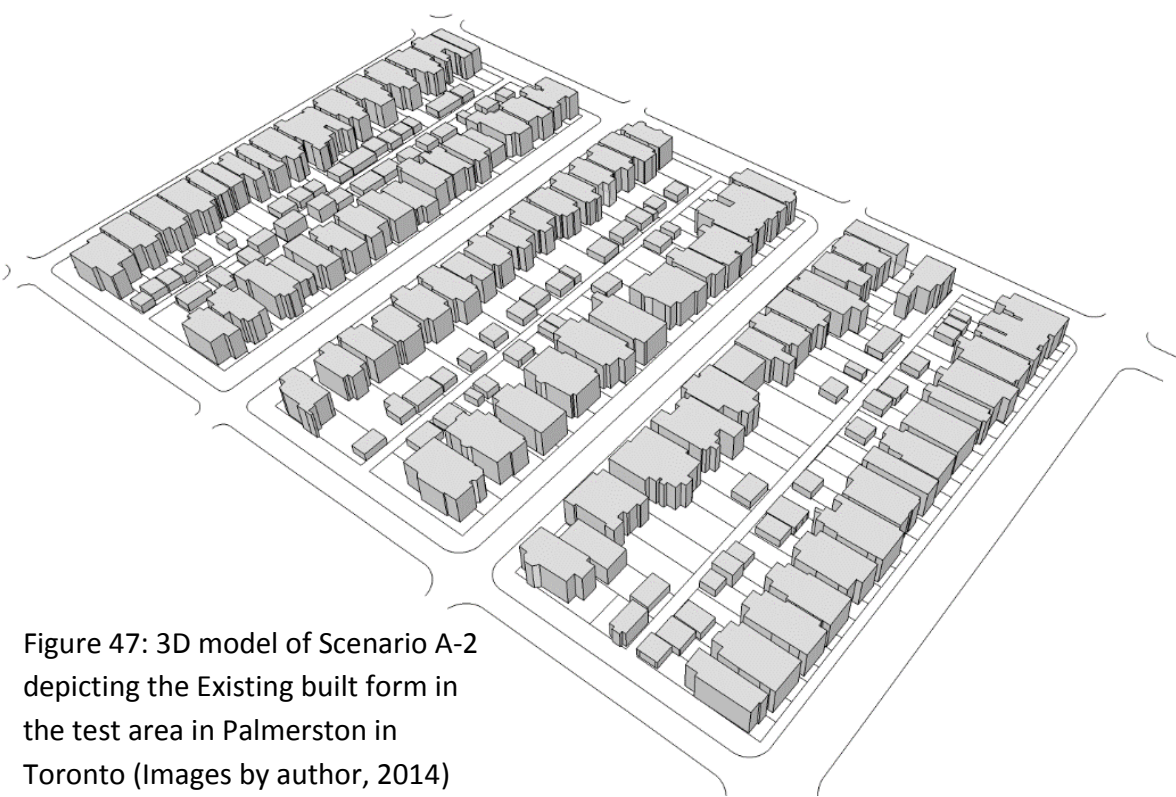

Scenario A-2 presents the existing built form in the area and informal units within the existing fabric. The built form in this scenario is the same as the built form in Scenario A-1. In this scenario the number of dwelling units includes both legal and informal units. The number of dwelling units is estimated by analyzing collected data from field observations. For example, if a building had seven mail boxes while having only one hydro meter, it would appear that the building had seven units, including one legal and six informal units. The single hydro meter indicates that Toronto Hydro recognizes only one unit as legal.

A high level informality including 110 informal units was observed in the test area. Scenario A-2 illustrates that how informal units can increase density while maintaining the character of neighbourhood as the informal units in the test area are mainly located within the existing built form and do not impact morphology in a major way.

Pedestrian visual zone

Existing building

Additional building
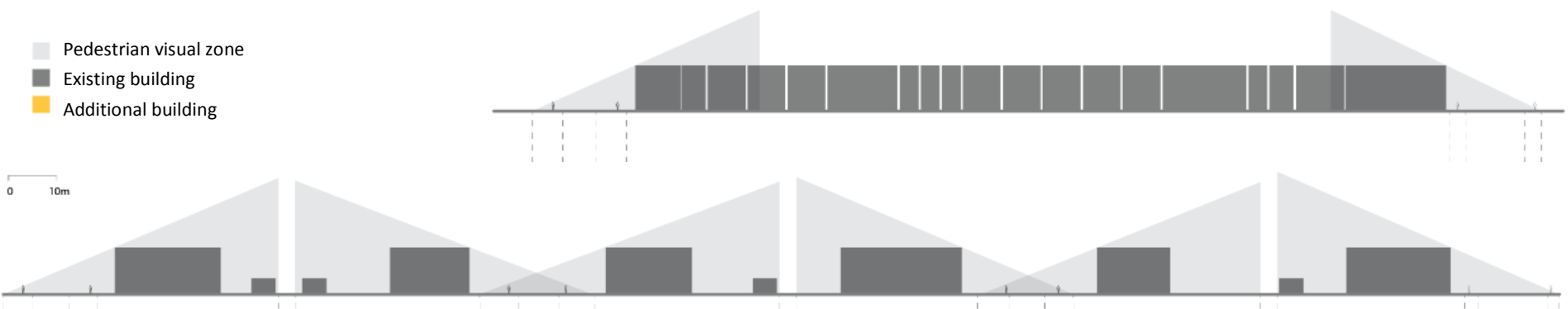

Figure 49 and 50: Schematic section illustrating the pedestrian visual zone from street and the built form in Scenario A-2 (Images by author, 2014) 
Number of dwelling units per property
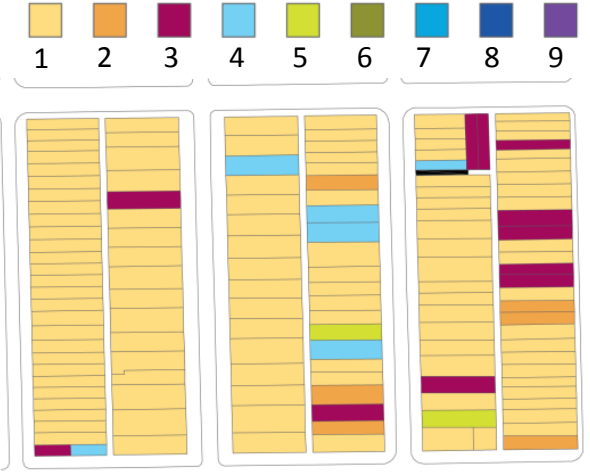

Figure 51: Plan diagram for Scenario A-3 presenting the number of legal dwelling units on each property in the test area in Palmerston in Toronto (Images by author, 2014)

1-Applies to all properties

2- Maintains the existing zoning requirements including:

- Maximum Floor Space Index (FSI) of 0.6 meaning the ratio of total floor area to lot area should be 0.6 or less

- Maximum height of 10 metres

Scenario A-3 illustrates how the test area would look like if all properties were built with the height of 10 metres and FSI of 0.6 according to the existing Zoning Bylaw. This scenario assumes that all units are legal and considers the same number of dwelling units as Scenario A-1. The existing as-of-right maintains neighborhood character by maintaining physical patterns in the areas such as setbacks and height.

However, this scenario has smaller buildings and more unused space on each property. A comparison of as-of-right scenario to the existing built form indicates that all of the properties except one have exceeded the existing zoning requirements.
Scenario A: Existing Condition Governed by the Zoning By-law Scenario A-3: Existing as-of-right

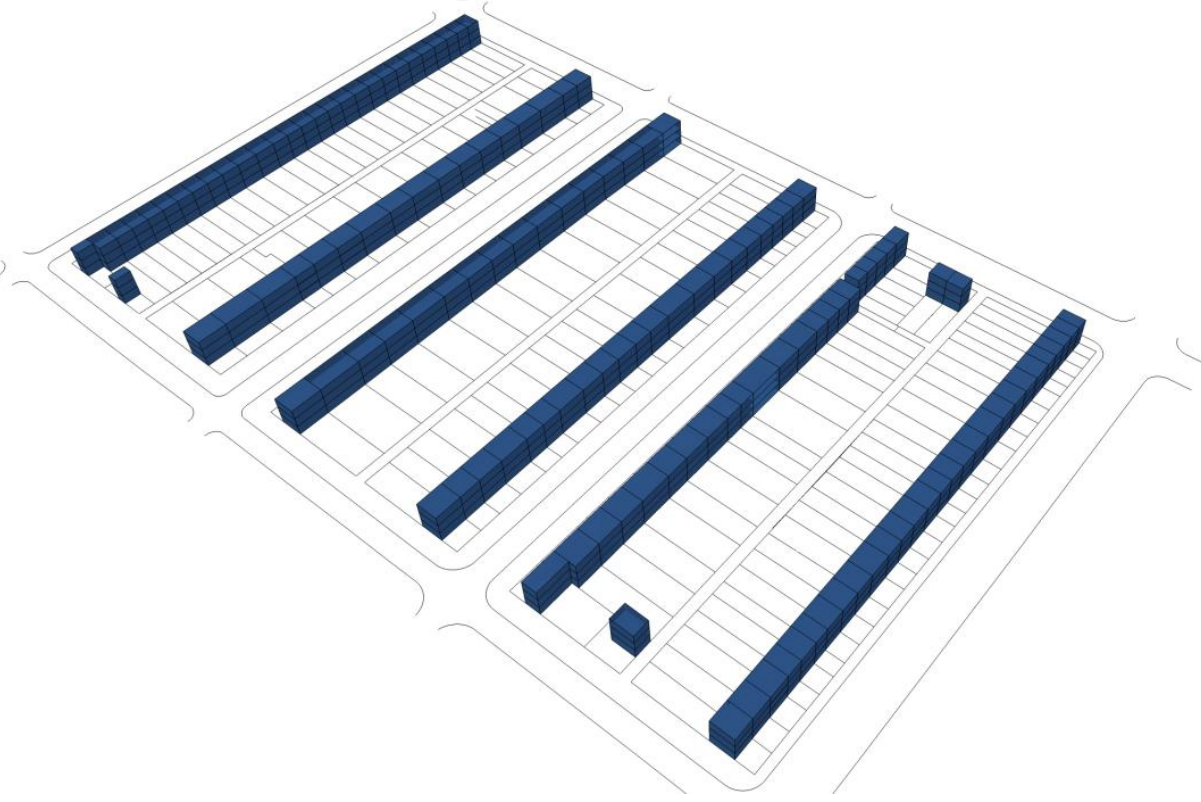

Figure 52: 3D model of Scenario A-3 depicting the Existing as-of-right in the test area in Palmerston in Toronto (Images by author, 2014)

$\begin{array}{ll}\text { Density } & \text { Number of } \\ \text { (units/ha): } & \text { Units: } \\ 34.7 & 191\end{array}$

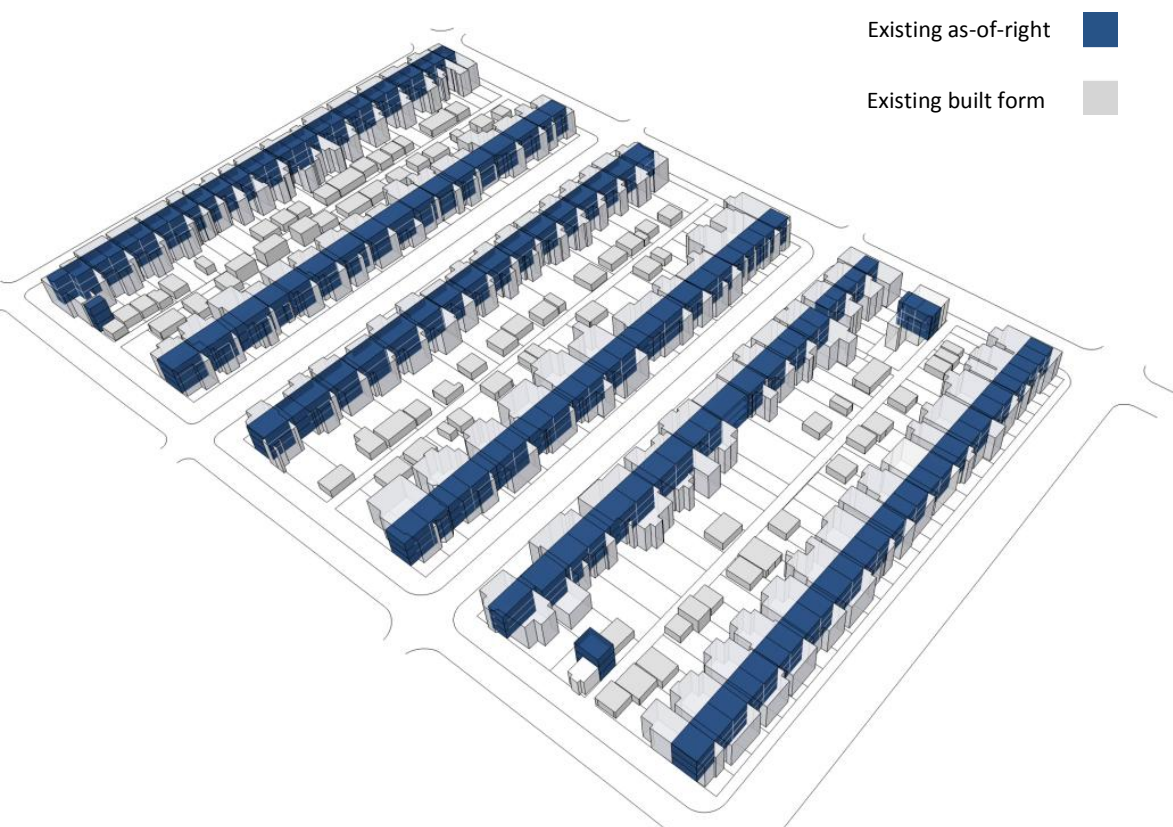

Figure 53: 3D model of Scenario A-3 laid on top of the existing built form as-of-right in the test area in Palmerston in Toronto (Images by author, 2014) 
Number of dwelling units per property
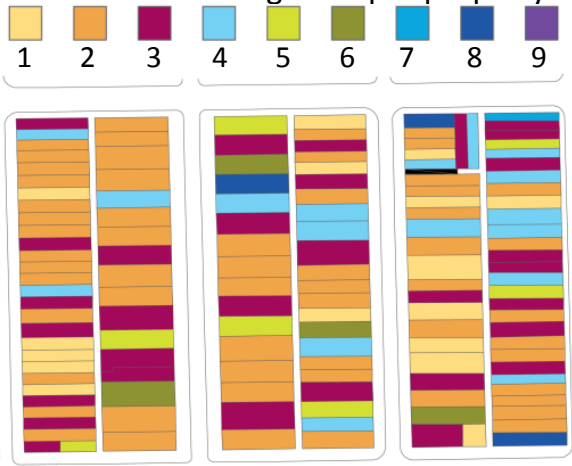

Figure 54: Plan diagram for Scenario B -1 presenting the number of dwelling units on each property in the test area in

Palmerston in Toronto (Images by author, 2014)

\section{Density (units/ha): Number of \\ 69.9 Units: 383}

Eighty properties in the area have a detached garage on laneway, and four of these garages have already a suite above. Scenario B-1 is applied to all 80 properties that have a garage, and a suite is added to above each garage. It is assumed that each suite above a garage include one dwelling unit. This scenario does not change the integrity of neighbourhood character in a major way and does not exceed the height limit of existing zoning. This scenario adds 82 units and increase density of the area to 69.6 .

\section{Scenario B: $\quad$ Addition of suites located above garages, with height restriction of 10 metres}

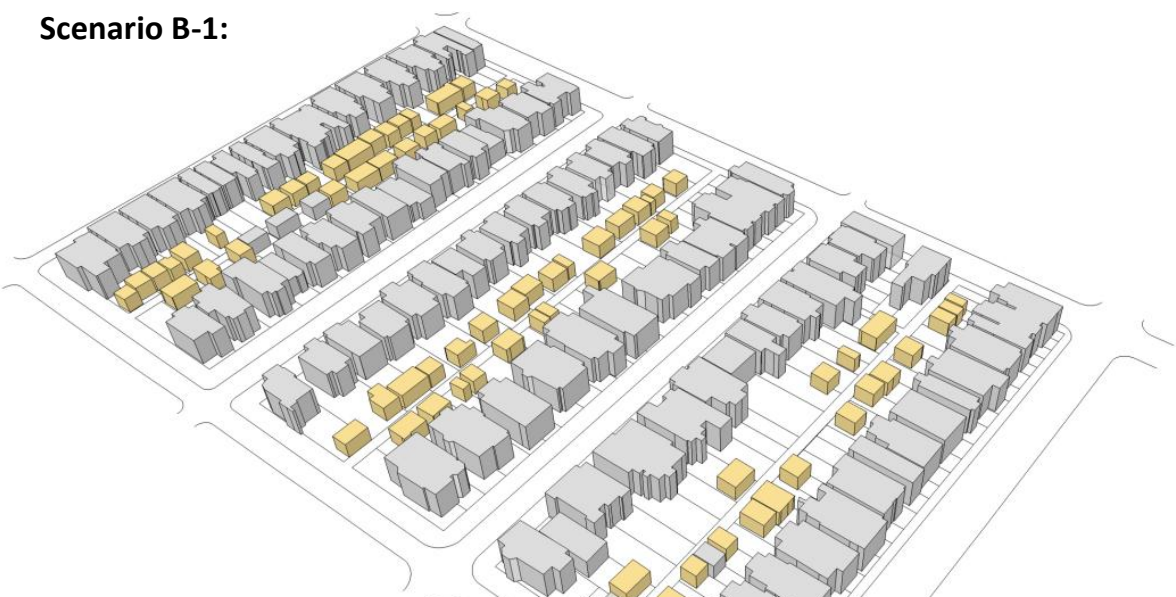

Figure 55: 3D model of Scenario B-1 depicting the Addition of suites located above garages in the test area in Palmerston in Toronto (Images by author, 2014)

Existing as-of-right Addition of suites Existing built form

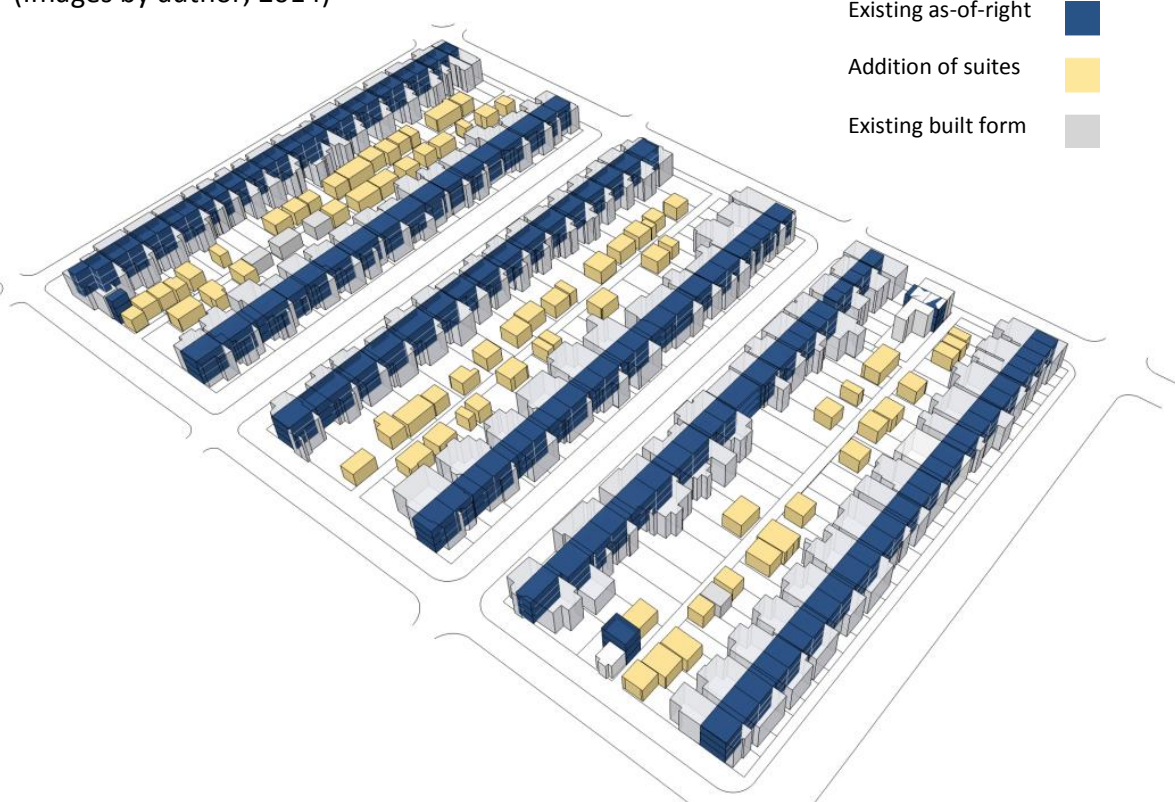

Figure 56: 3D model of existing as-of-right laid on top of the built form in Scenario B-1 in the test area in Palmerston in Toronto (Images by author, 2014)

Pedestrian visual zone Existing building Additional building
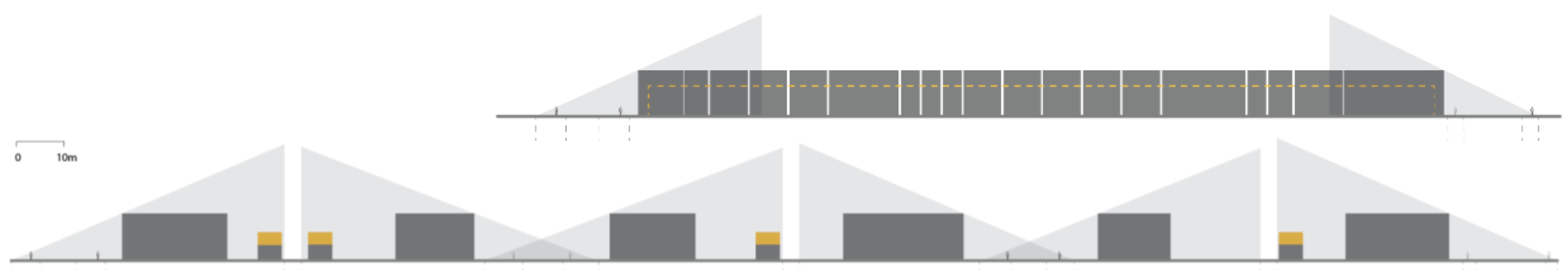

Figure 57 and 58: Schematic section illustrating the pedestrian visual zone from street and the built form in Scenario B-1 (Images by author, 2014) 
Number of dwelling units per property
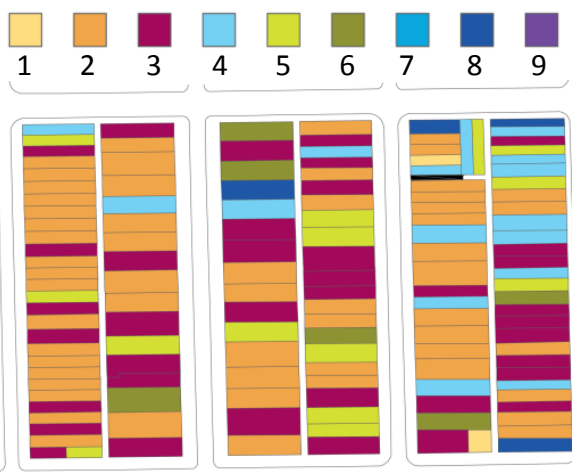

Figure 59: Plan diagram for Scenario B -2 presenting the number of dwelling units on each property in the test area in Palmerston in Toronto (Images by author, 2014)

\section{Scenario B: $\quad$ Addition of suites located above garages, with height} restriction of $\mathbf{1 0}$ metres

\section{Scenario B-2:}

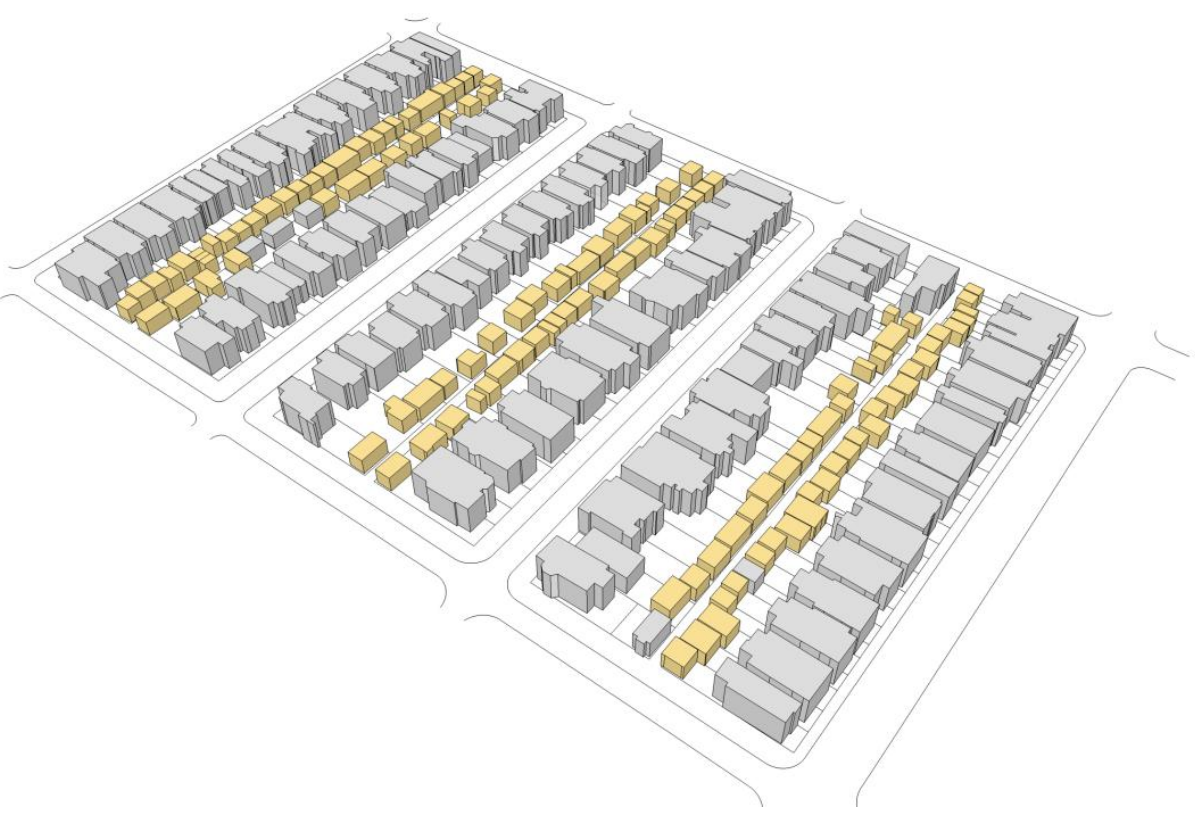

Figure 60: 3D model of Scenario B-2 depicting the Addition of suites located above garages in the test area in Palmerston in Toronto (Images by author, 2014)

Scenario B-2 applies to all of the properties either with or without an existing garage. This scenario illustrates how test area would look like if all of the properties have a detached garage and a suite located above garage on laneways. Assuming that each suite above a garage includes one dwelling unit, density increases to 78.2 units per hectare. Comparing Scenario B-2 and as-of-right scenario highlights the difference between massing and also number of units. Scenario B-2 exceeds as of right by 43.5 units per hectare in density while changing the neighborhood character in a minor way, by maintaining height limit. 
Scenario B: Addition of suites located above garages, with height restriction of 10 metres

\section{Continued from Scenario B-2:}

Density

(units/ha):

78.2

Number of

Units:

430
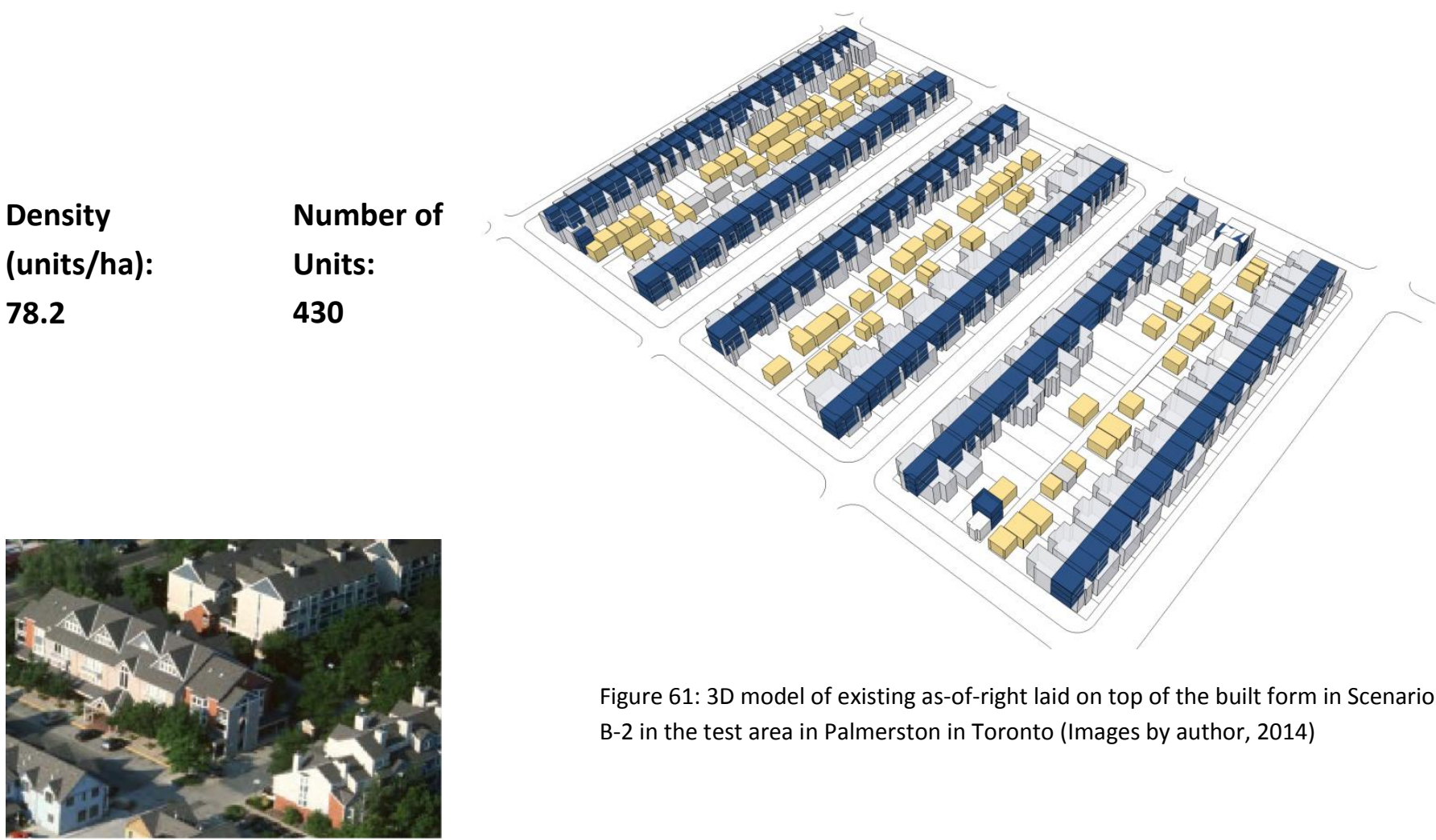

Figure 61: 3D model of existing as-of-right laid on top of the built form in Scenario

B-2 in the test area in Palmerston in Toronto (Images by author, 2014)

Figure 62: Boulder, CO with similar density as Scenario B-2 (Campoli and MacLean, 2007)

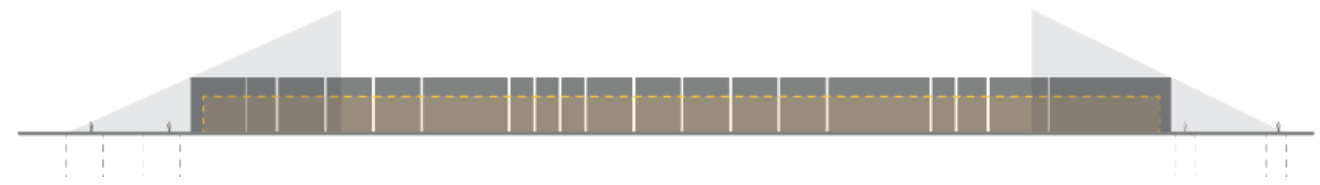

Pedestrian visual zone Existing building Additional building

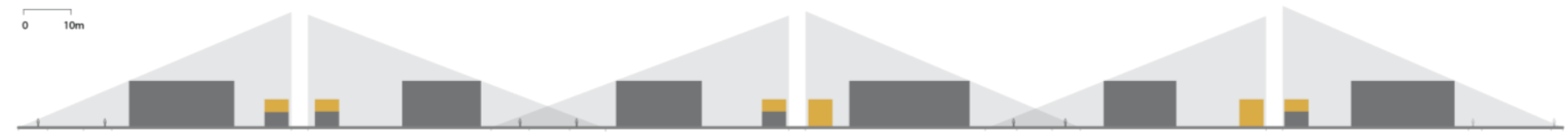

Figure 63 and 64: Schematic section illustrating the pedestrian visual zone from street and the built form in Scenario B-2 (Images by author, 2014) 
Number of dwelling units per property

$\begin{array}{llllllllll}\square & \square & \square & \square & \square & & & & \\ 1 & 2 & 3 & 4 & 5 & 6 & 7 & 8 & 9\end{array}$
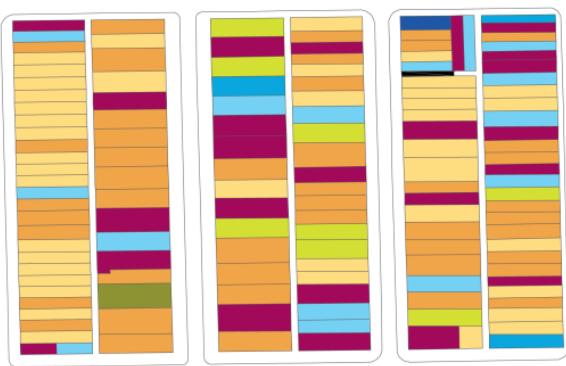

Figure 65: Plan diagram for Scenario C -1 presenting the number of dwelling units on each property in the test area in Palmerston in Toronto (Images by author, 2014)

1- Based on the actual existing

condition noticed informality

(Scenario 1-2)

2- Applies to properties with

- Minimum lot size of $7.3 \mathrm{~m}$, and

- Minimum side yard setback of 0.9 m for the existing building for fire access from main street (City of Vancouver, 2013).

\section{Scenario C: Addition of Laneway houses, with height restriction of $10 \mathrm{~m}$}

Scenario C-1: Addition of 1 storey Laneway housing based on the "Laneway Housing How-To Guide" created by the City of Vancouver.

\section{Scenario C-1-1:}

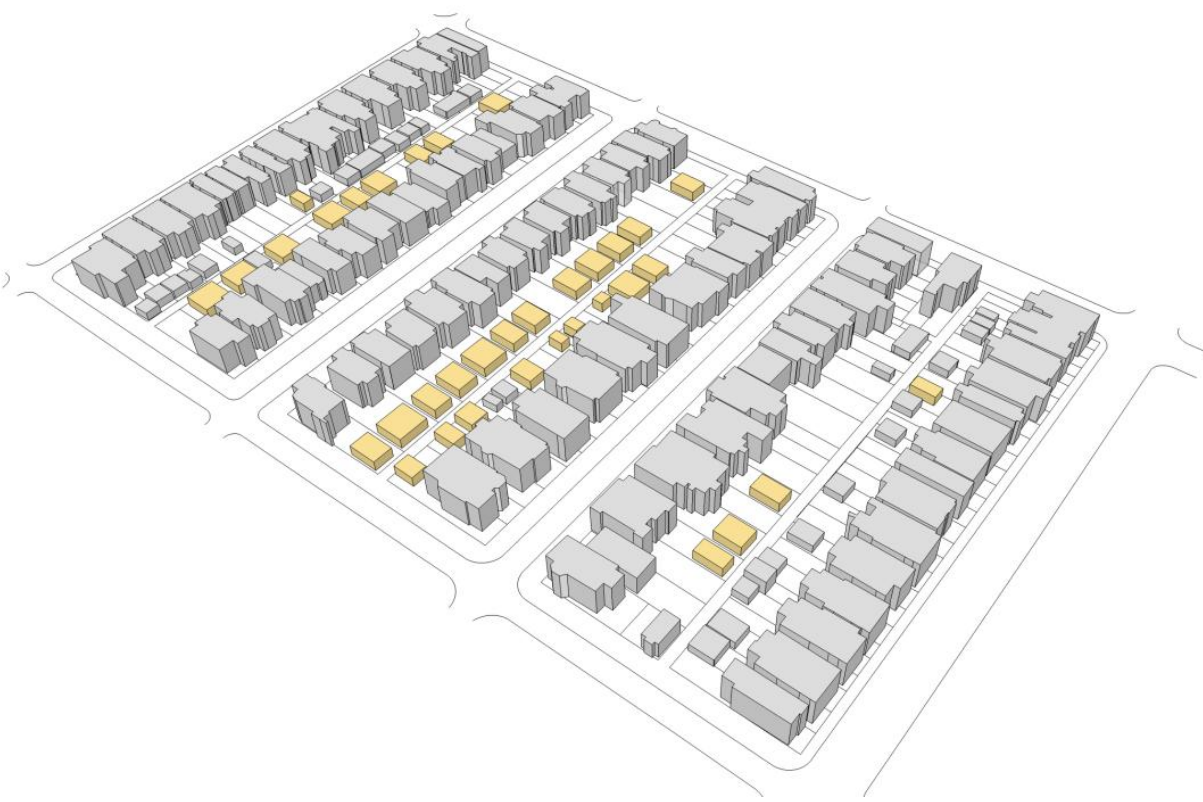

Figure 66: 3D model of Scenario C-1-1 depicting the addition of one storey laneway houses in the test area in Palmerston in Toronto (Images by author, 2014)

Employing the City of Vancouver laneway housing guideline, Scenario C-1 and C-2 illustrate how test area would have been changed and the Vancouver guideline was implemented in the area.

The "Laneway Housing How-To Guide" by the City of Vancouver suggests that laneway houses can be 1 storey or 1.5 storeys. According to the Vancouver guideline a property is eligible for the addition of laneway house if it has minimum lot width of 7.3. It also determines a minimum side yard setback for the main house for providing fire access to laneway house from street. 


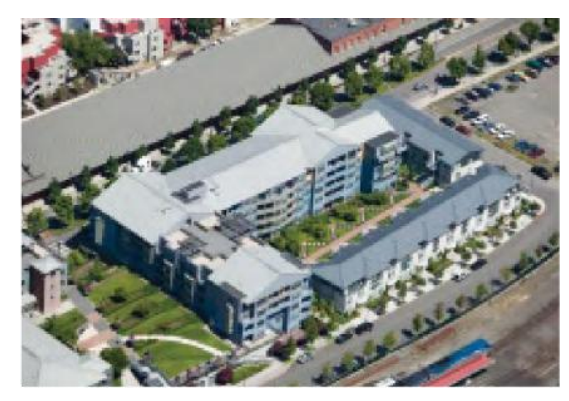

Figure 67: Portland, OR with similar density as Scenario B-2 (Campoli and MacLean, 2007)
Scenario C: Addition of Laneway houses, with height restriction of $10 \mathrm{~m}$ Scenario C-1: Addition of 1 storey Laneway housing based on the "Laneway Housing How-To Guide" created by the City of Vancouver.

\section{Continued from Scenario C-1-1:}

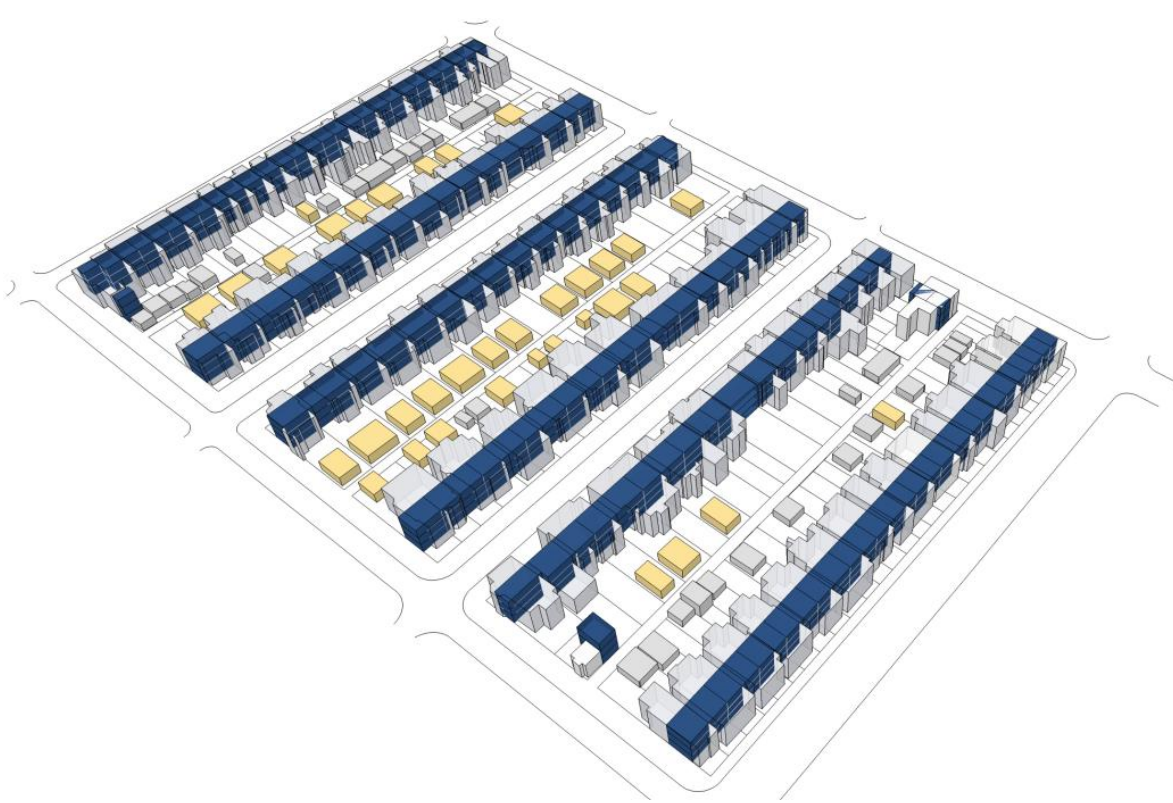

Figure 68: 3D model of existing as-of-right laid on top of the built form in Scenario C-1-1 in the test area in Palmerston in Toronto (Images by author, 2014)

Scenario C-1-1 illustrates the test area with the addition of one storey laneway houses based on the Vancouver guideline. This scenario is applied to 35 properties including those meet the minimum requirements for side yard setback and lot width. Assuming that each laneway house is a single dwelling unit, 36 units are produced increasing density to 61.3. Similar to Scenario B-1 and B-2 this scenario maintains the neighbourhood character.

\section{3}

337

\section{Units:}


Scenario C-1-2 illustrates what

could be possible if Vancouver laneway model was implemented on all properties with minimum lot width of 7.3 metres. This scenario does not utilizes the side yard setback requirements to illustrate the change in density and morphology, assuming that fire access would be provided from laneways or existing houses were replaced by new buildings with minimum side yard setback of 0.9 metre. Scenario C-1-2 applies to 60 properties and produced 61 units. It is assumed that each laneway house has one dwelling unit. Given the height of laneway houses this scenario does not impact neighbourhood character in a major way while increasing density to 65.8 units per hectare.

\section{Density Number of (units/ha): Units:}

$65.8 \quad 362$

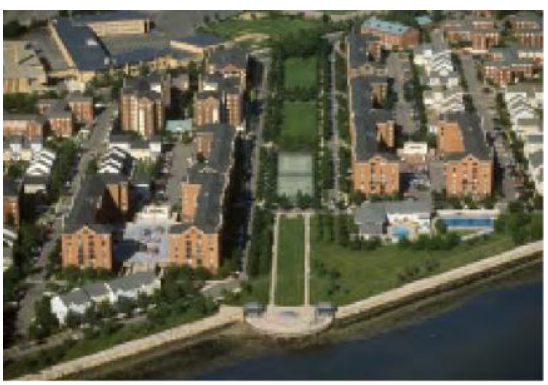

Figure 73: Boston, MI with similar density as Scenario B-2 (Campoli and MacLean, 2007)
Scenario C: Addition of Laneway houses, with height restriction of $10 \mathrm{~m}$ Scenario C-1: Addition of 1 storey Laneway housing based on the "Laneway Housing How-To Guide" created by the City of Vancouver.

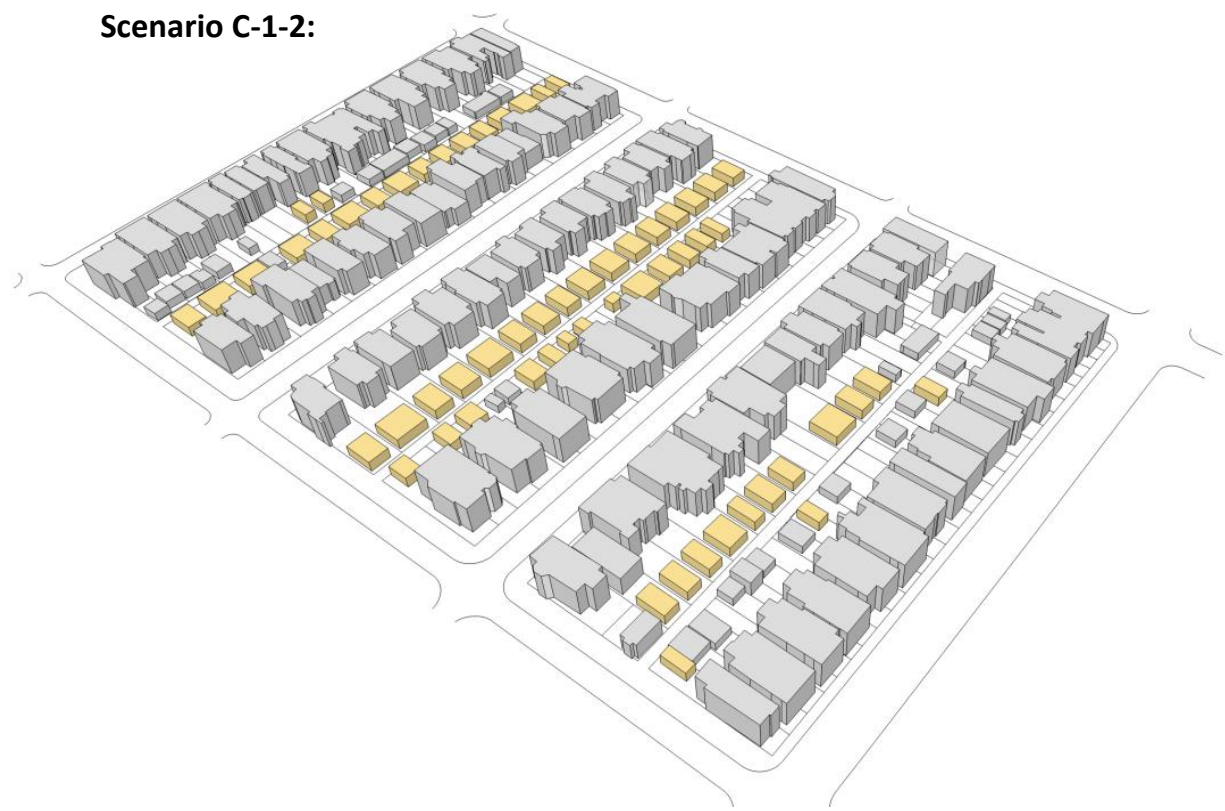

Figure 71: 3D model of Scenario C-1-2 depicting the addition of one storey laneway houses in the test area in Palmerston in Toronto (Images by author, 2014)

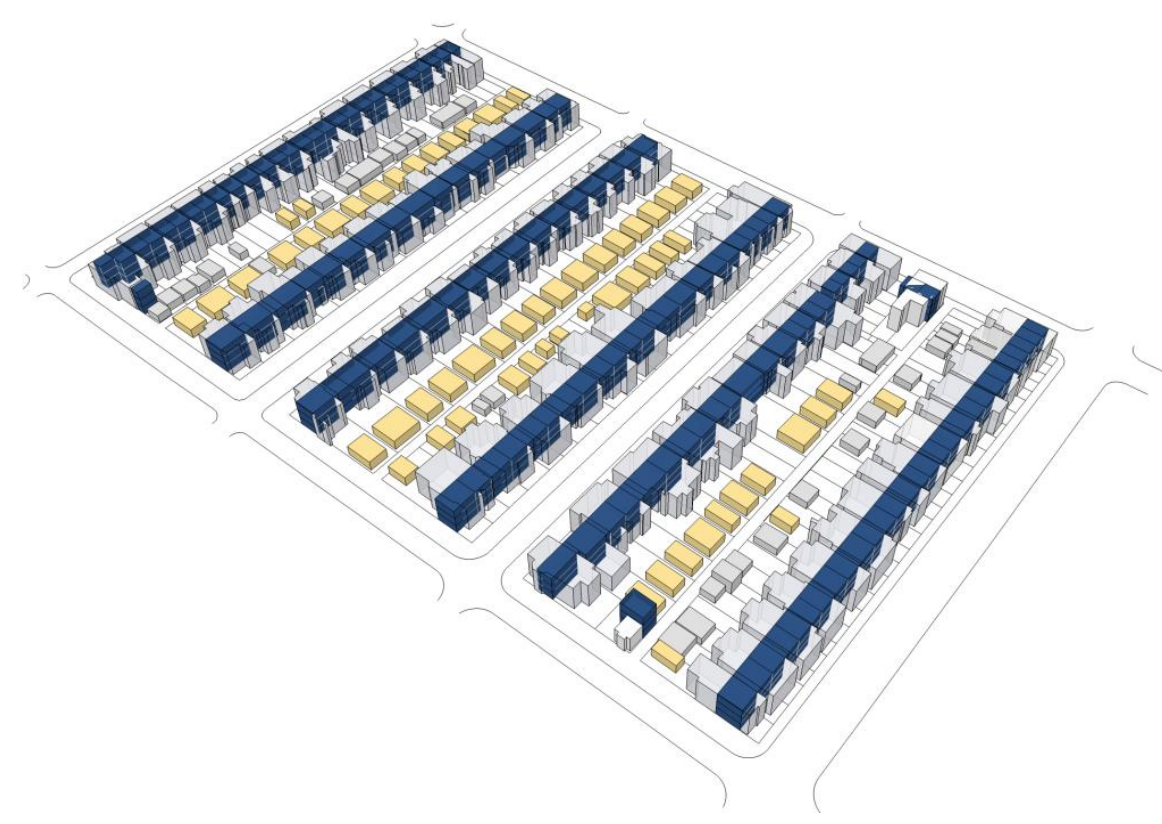

Figure 72: 3D model of existing as-of-right laid on top of the built form in Scenario C-1-2 in the test area in Palmerston in Toronto (Images by author, 2014) 
Number of dwelling units per property
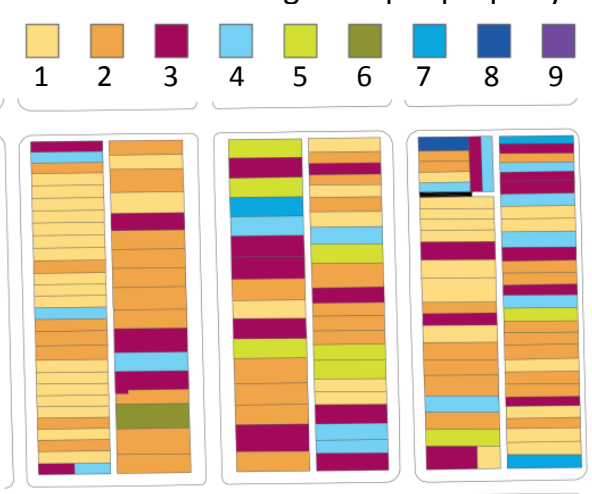

Figure 74: Plan diagram for Scenario C -2 presenting the number of dwelling units on each property in the test area in

Palmerston in Toronto (Images by author, 2014)

Scenario C-2 illustrates the test area with the addition of 1.5 storey laneway houses based on the Vanouver laneway housing guideline. Scenario C-2-1 applies to 35 properties those meet the minimum requirements for lot width and side yard setback. Assuming that each 1.5 storeys laneway house is a single dwelling unit, the density of this scenario is same as scenario C-1-1 with 337 units and density of 61.3 units per hectare. Although this scenario increases density it retains the character of neighbourhood.

\section{Scenario C: Addition of Laneway houses, with height restriction of $10 \mathrm{~m}$}

Scenario C-2: Addition of 1.5 storey Laneway housing based on the "Laneway Housing How-To Guide" created by the City of Vancouver.

\section{Scenario C-2-1:}

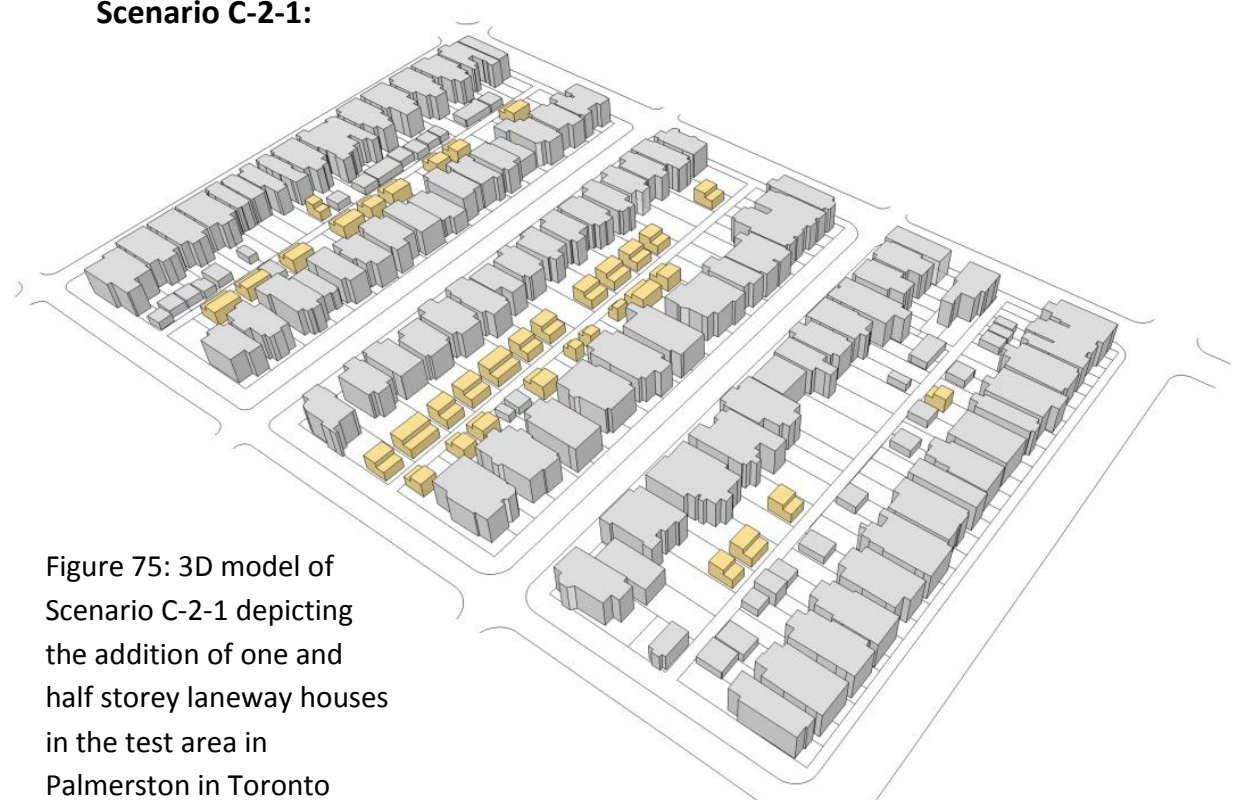

(Images by author, 2014)

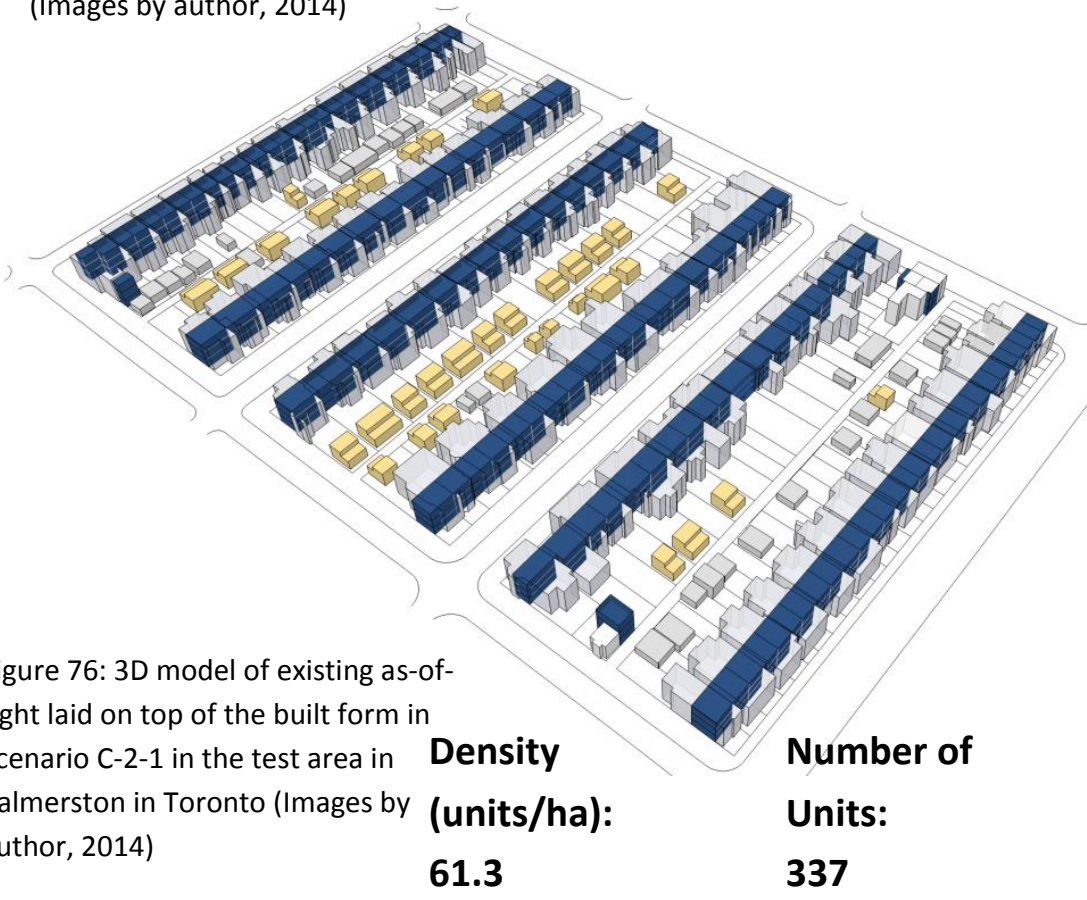

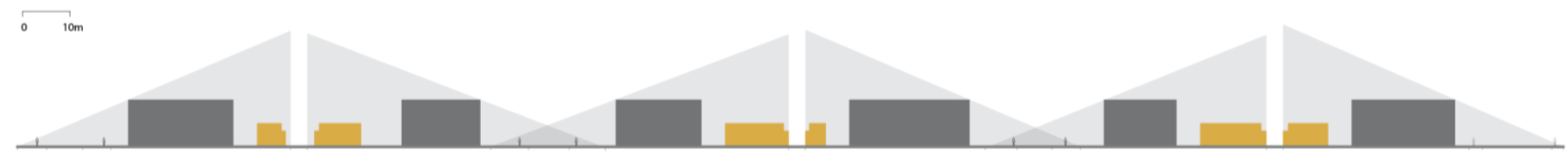

Figure 77: Schematic section \#1 illustrating the pedestrian visual zone from street and the built form in Scenario C-2 (Images by author, 2014) 
1- Based on actual existing condition noticed informality (Scenario 1-2)

2- Applies to properties with minimum lot size of $7.3 \mathrm{~m}$ (City of Vancouver, 2013).

It is assumed that each laneway house is a single dwelling unit.

Scenario C-2-2 illustrates the addition of 1.5 storey laneway houses to properties with the minimum width of 7.3 metres and without considering the side yard setback requirement. Similar to Scenario C-1-2, it is assumed that fire access would be provided from laneways or existing houses were replaced by new buildings with minimum side yard setback of 0.9 metre. This scenario applies to 61 properties and adding 61 extra units. Assuming each 1.5 storey laneway house as a single unit, density was increased to 65.8 units per hectare.

This scenario respects neighbourhood character however it exceeds the as-of-right in terms of built form and also number of units.

Density $\quad$ Number of

65.8
Scenario C: Addition of Laneway houses, with height restriction of $10 \mathrm{~m}$ Scenario C-2: Addition of 1.5 storey Laneway housing based on the "Laneway Housing How-To Guide" created by the City of Vancouver.
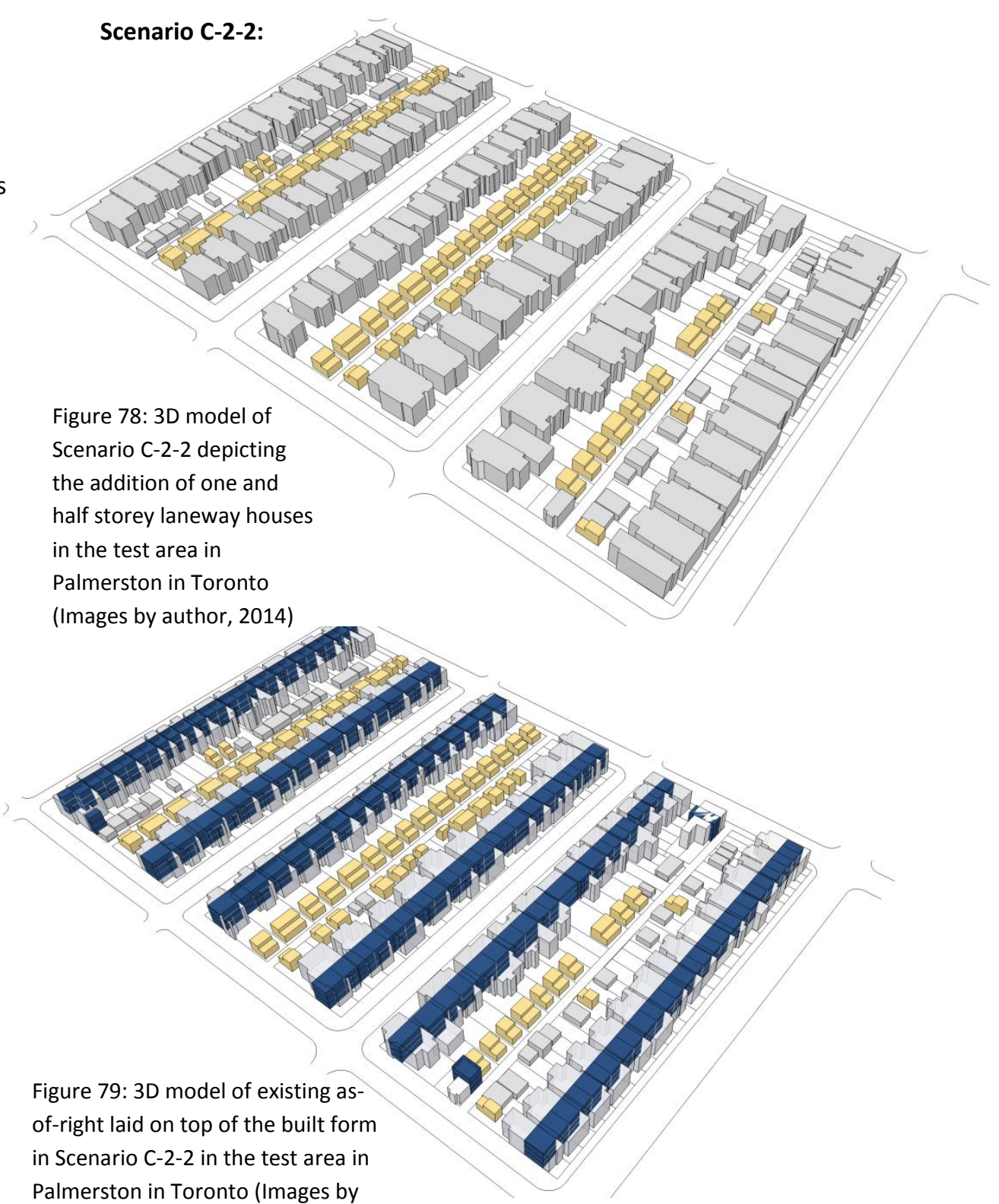
author, 2014)

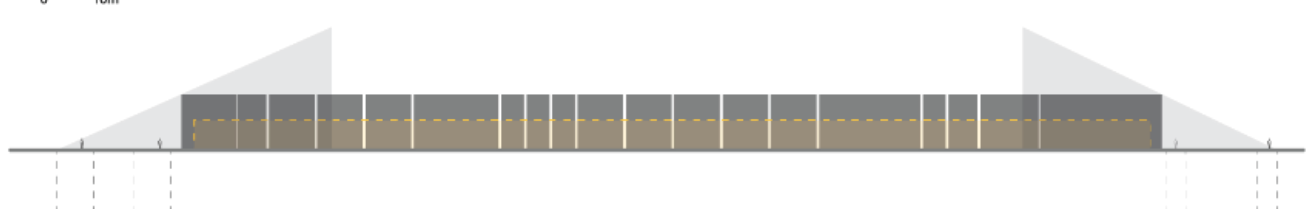

Figure 80: Schematic section \#2 illustrating the pedestrian visual zone from street and the built form in Scenario C-2 (Images by author, 2014) 
Number of dwelling units per property
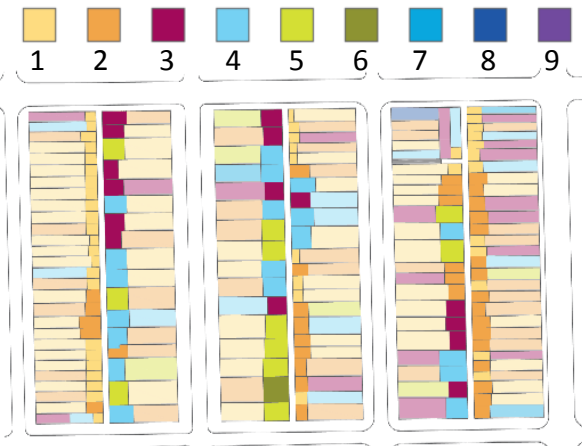

Figure 81: Plan diagram for Scenario C -3 presenting the number of dwelling units produced by each laneway house in the test area in Palmerston in Toronto (Images by author, 2014)

Number of dwelling units per property
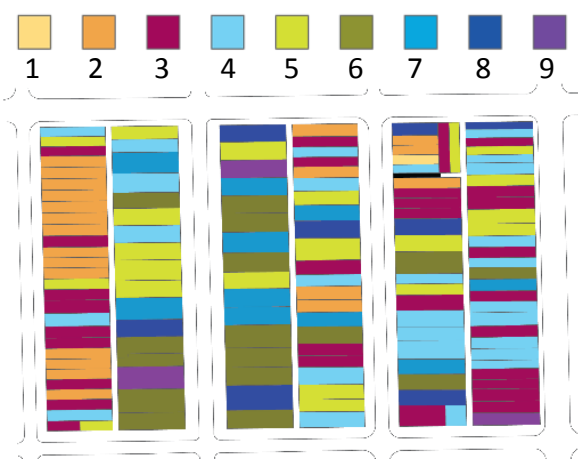

Figure 82: Plan diagram for Scenario C -3 presenting the number of dwelling units on each property in the test area in Palmerston in Toronto (Images by author, 2014)

$\begin{array}{ll}\text { Density } & \text { Number of } \\ \text { (units/ha): } & \text { Units: } \\ 109.6 & 603\end{array}$

\section{Scenario C: Addition of Laneway houses, with height restriction of $10 \mathrm{~m}$}

Scenario C-3: Addition of 3 storey Laneway housing based on Stinson- Van Elsander model for slot lots

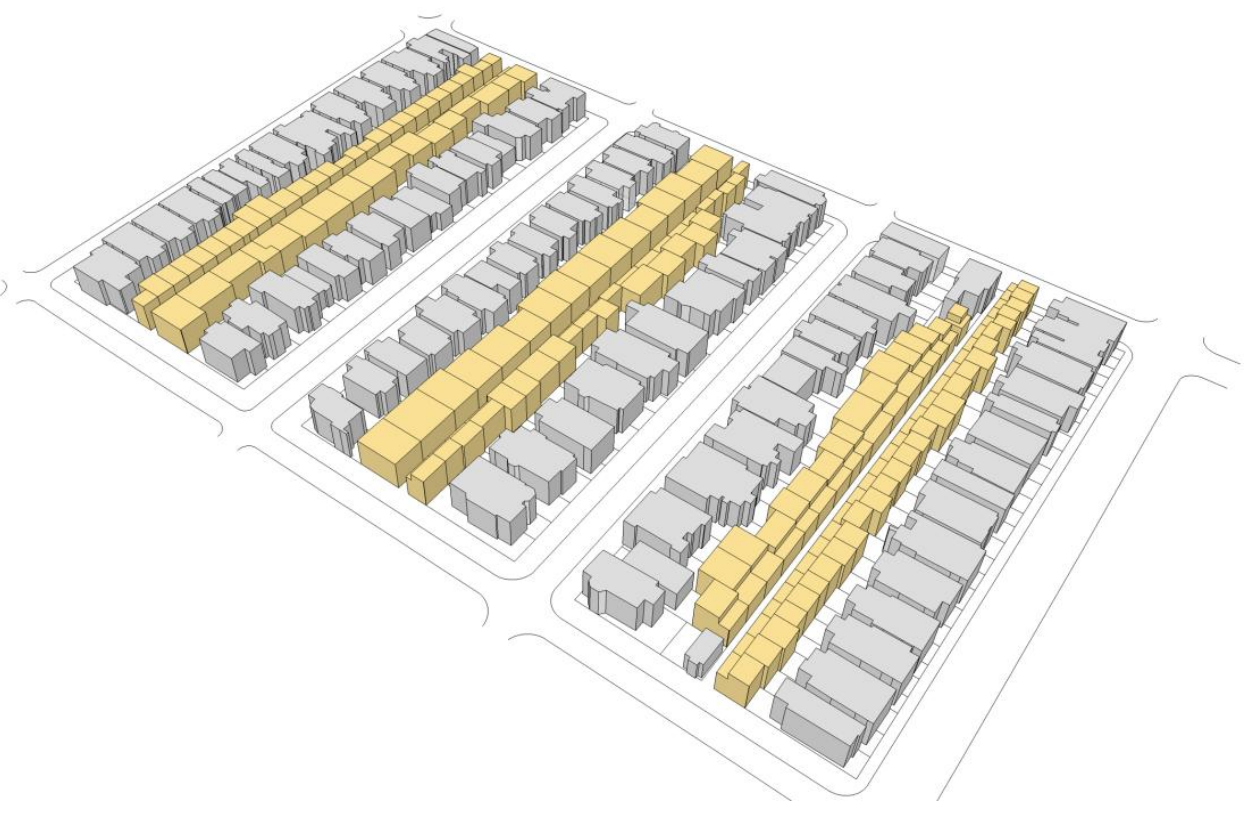

Figure 83: 3D model of Scenario C-3 depicting the addition of three storey laneway houses in the test area in Palmerston in Toronto (Images by author, 2014)

1- Based on actual existing condition noticed informality (Scenario A-2)

2- Applies to properties with average back yard depth of $14.5 \mathrm{~m}$ and minimum width of $5 \mathrm{~m}$.

Scenario C-3 is applied to all properties those have access to laneways and meet lot size requirement. This scenario adds three storey laneway houses with balcony and roof garden, maintaining a 6 metres open space between main house and laneway house and also a parking space for the main house. 
Scenario C: Addition of Laneway houses, with height restriction of $10 \mathrm{~m}$

\section{Continued from Scenario C-3}

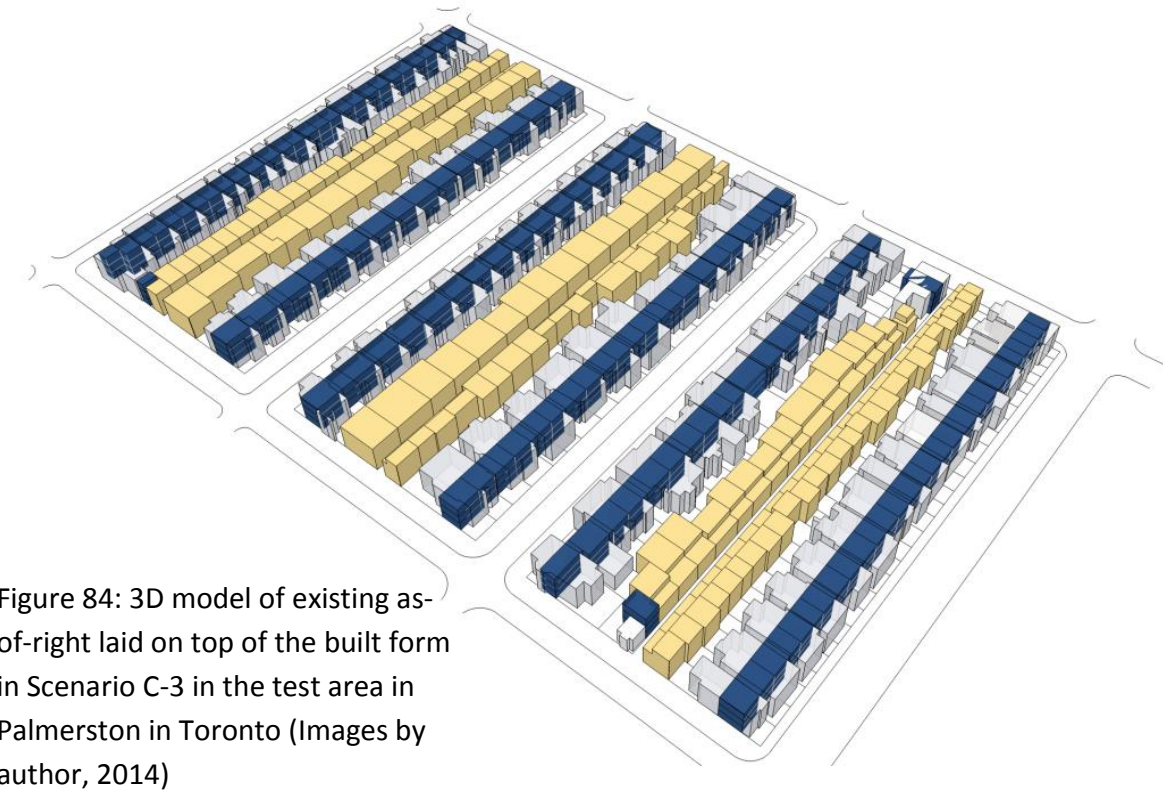

In this scenario 128 buildings including 302 dwelling units are

added. To calculate the number of additional dwelling units on a property, it is assumed that:

- Minimum unit area of 26 square metres

- Average parking area of 20 square metres

- Efficiency ratio of $80 \%$

This scenario increases density to 109.6 while maintaining the street character. However, it can be argued that Scenario C-3 impacts the character by changing building massing. In addition, the $50 \%$ rise in number of units can pressurize existing infrastructure and increasing the issues of overlook, privacy and shadowing.
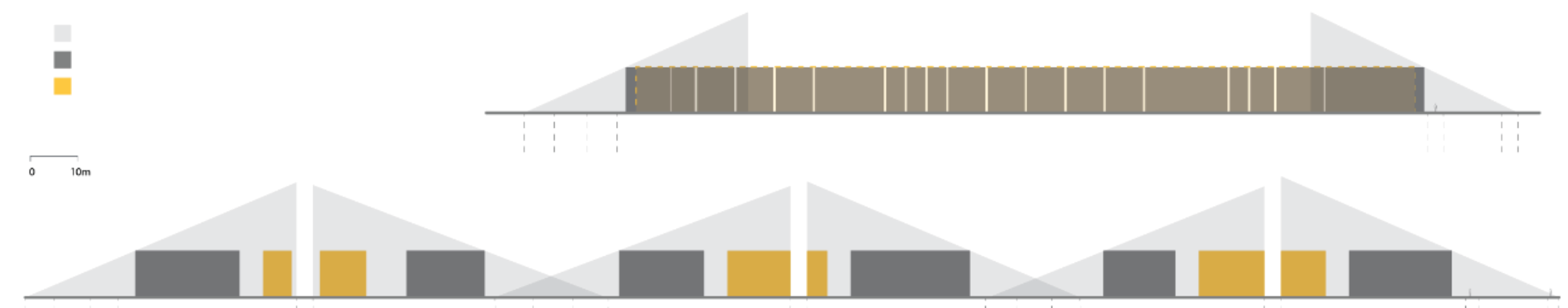

Figure 86 and 87: Schematic section illustrating the pedestrian visual zone from street and the built form in Scenario C-3 (Images by author, 2014) 
Number of dwelling units per property
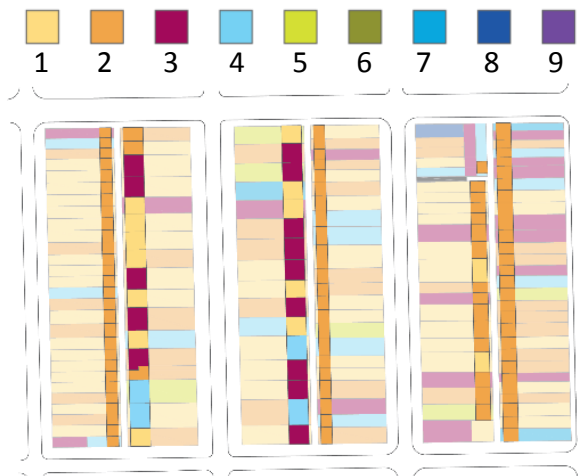

Figure 88: Plan diagram for Scenario $D$ presenting the number of dwelling units produced by each laneway house, ground floor, in the test area in Palmerston in Toronto (Images by author, 2014)

Number of dwelling units per property
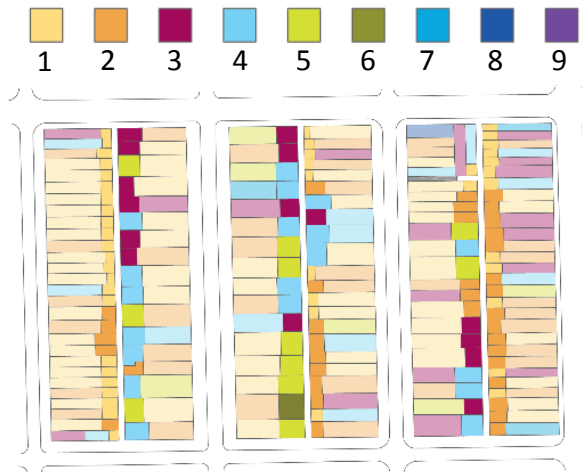

Figure 89: Plan diagram for Scenario D presenting the number of dwelling units produced by each laneway house, upper floors, in the test area in Palmerston in Toronto (Images by author, 2014)

1- Applies to all properties with access to laneway

2- Addition of laneway houses. The height of laneway developments should not be visible from front streets. This would be established as the only zoning restriction.

\section{3- Allows laneway developments} with maximum 6 storey
Scenario D: Laneway developments while maintaining physical character beyond current Zoning By-law

\section{Scenario D-1:}

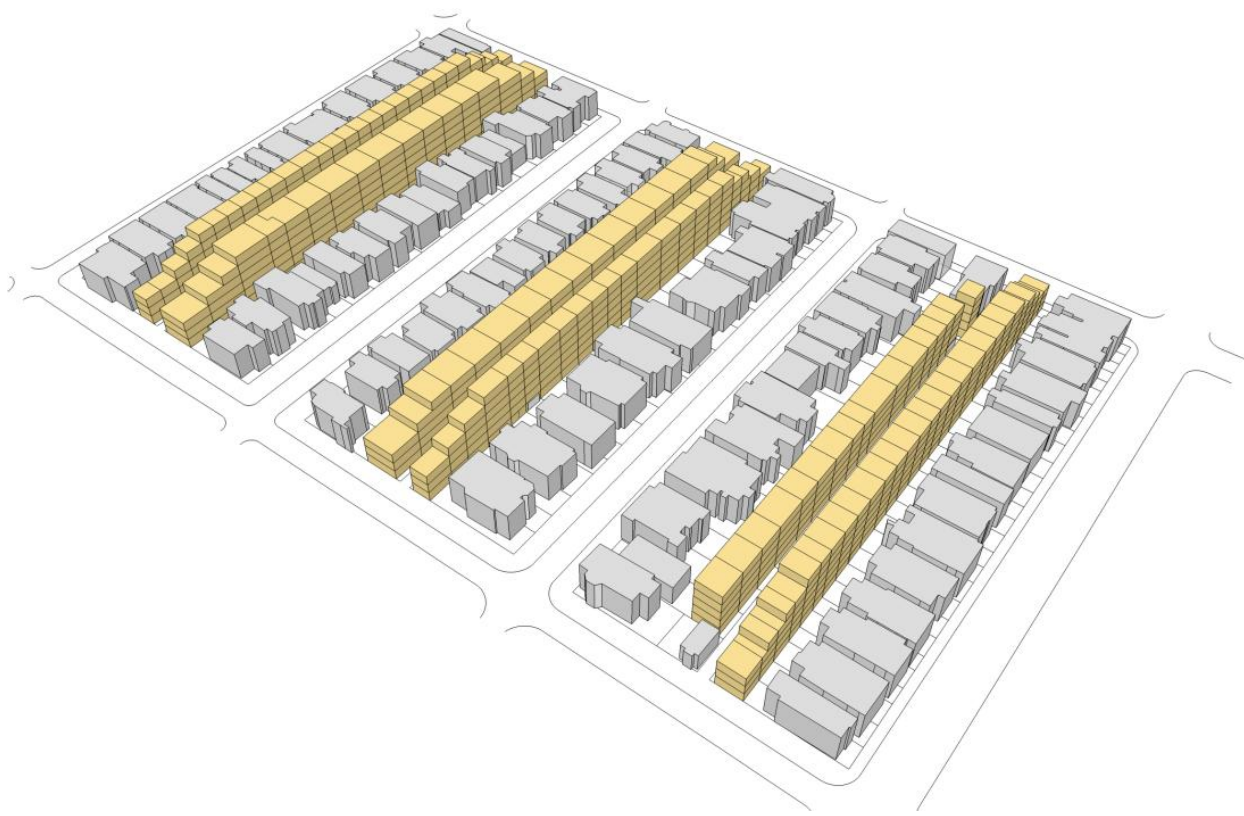

Figure 90: 3D model of Scenario D-1 depicting the addition of multi storey laneway houses in the test area in Palmerston in Toronto (Images by author, 2014)

Scenario D illustrates what could be possible if laneway house were built beyond the existing Zoning By-law while maintaining the character of neighbourhood.

Scenario D-1 determines the height of laneway developments based on what can be visible from street. A combination of three, four, five and six storey buildings is added on laneways. This scenario increases density to 264 including 1452 dwelling units.

Similar to Scenario C-3 assumes that minimum unit area is 26 sqm, parking space is provided for main house with average area of 20 sqm and the efficiency ratio is $80 \%$. 
Scenario D: Laneway developments while maintaining physical character beyond current Zoning By-law

\section{Continued from Scenario D-1:}

Density

(units/ha):

264

\section{Number of}

Units:

1452

Figure 91: 3D model of existing asof-right laid on top of the built form in Scenario D-1 in the test area in Palmerston in Toronto (Images by author, 2014)

This scenario maintains neighbourhood character; however it indicates high risk of overlook, shadowing and privacy issues due to the major change in building massing. Given the considerable increase in density, this scenario can also pressurize existing infrastructure. In addition, laneway houses in Scenario D-1 will be more expensive than laneway houses with fewer storeys, as they should have elevator and
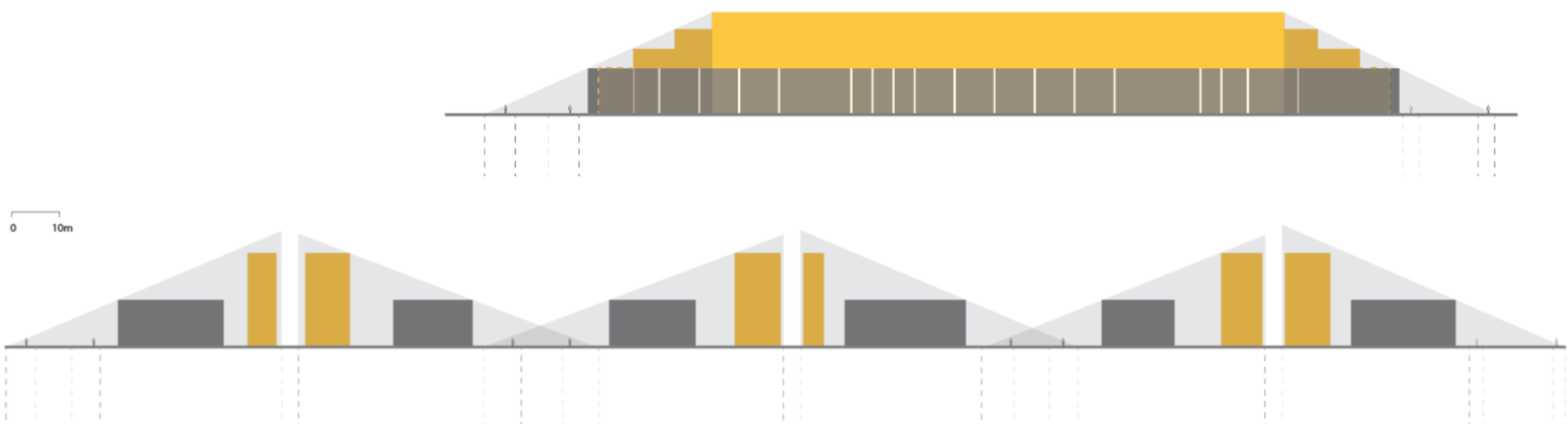

Figure 92 and 93: Schematic section illustrating the pedestrian visual zone from street and the built form in Scenario D-1 (Images by author, 2014) 


\section{Scenario D-2:}

1- Applies to all properties

2- Addition of laneway houses.

The height of laneway

developments should not be visible from front streets. This would be established as the only zoning restriction.

3- Allows laneway

developments with maximum

4 storey

Figure 94: 3D model of Scenario D -2

depicting the addition of multi

storey laneway houses in the test

area in Palmerston in Toronto

(Images by author, 2014)

Scenario D-2 is similar to Scenario D-1 and the only difference is the number of storeys. This scenario builds three and four storey laneway houses which cost less than five and six storey laneway house in Scenario D-1. This scenario is feasible due to the fact that it does not require steel structure and elevator. Scenario D-2 makes the same assumptions for minimum unit area, parking space and efficiency rate. This scenario increases the number of units to 1152 producing the

Density Number of (units/ha): Units: density of 209 units per hectare.

As Scenario D-1, this scenario can increase overlook, privacy and shadowing issues and can pressurize the existing infrastructure. Given what can be visible from surrounding streets, Scenario D-2 can maintain neighbourhood character. 


\section{Scenario D: Laneway developments while maintaining physical}

character beyond current Zoning By-law

\section{Continued from Scenario D-2:}

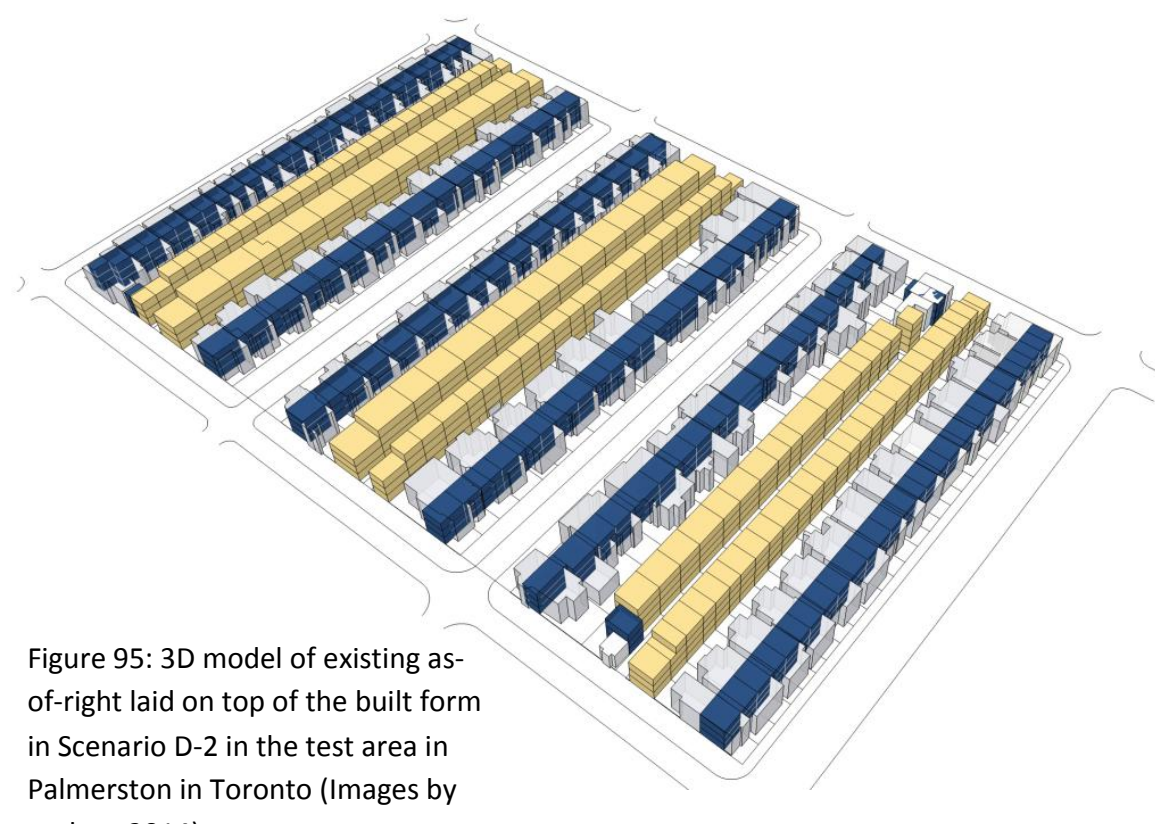

author, 2014)

As the morphology of Toronto is a result of incremental change in urban fabric, it is possible that this incremental change continues.

Considering the volume of building massing in Scenario C-3, D-1 and D-2, laneway houses can become the predominant built form in the area and gradually transform laneways to streets.
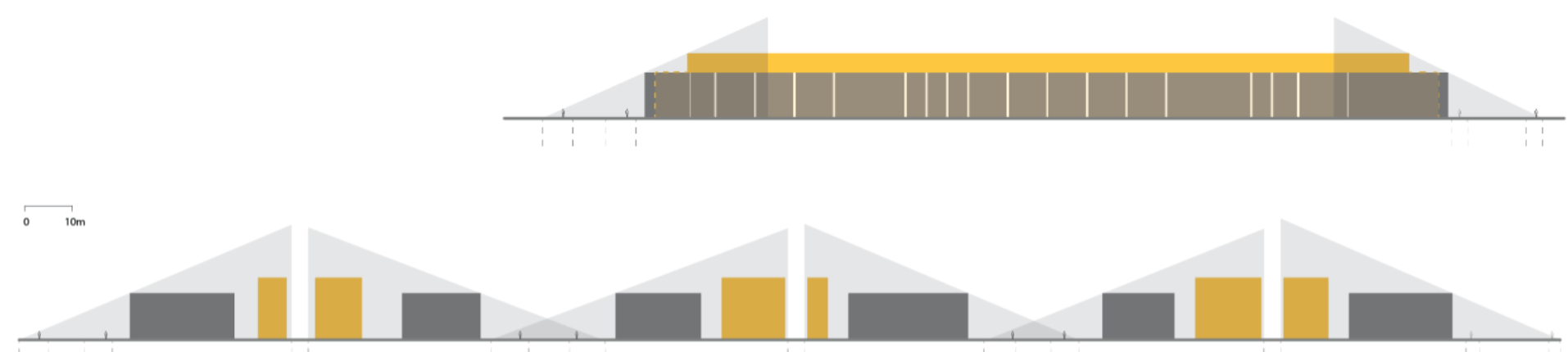

Figure 96 and 97: Schematic section illustrating the pedestrian visual zone from street and the built form in Scenario D-2 (Images by author, 2014) 


\begin{tabular}{|c|c|c|c|c|c|c|c|c|c|c|c|}
\hline \multirow[t]{2}{*}{ Scenario } & \multicolumn{2}{|c|}{ Anticipation } & \multicolumn{2}{|c|}{ Result } & \multicolumn{2}{|c|}{$\begin{array}{l}\text { Increase in as } \\
\text { of right }\end{array}$} & \multicolumn{2}{|l|}{ Pros } & \multicolumn{3}{|l|}{ Cons } \\
\hline & 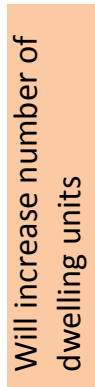 & 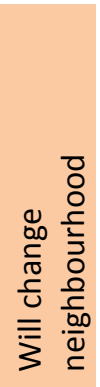 & 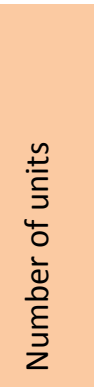 & 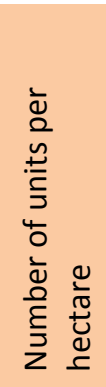 & 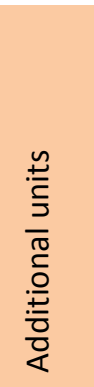 & 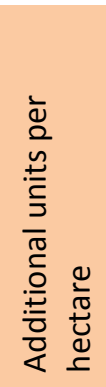 & 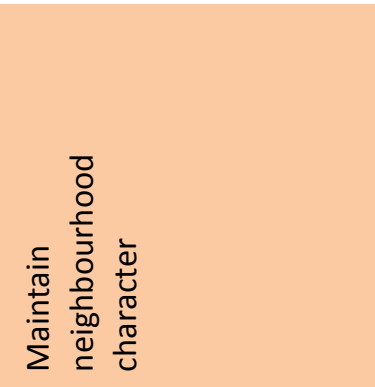 & 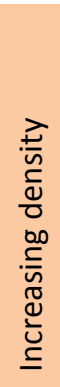 & $\begin{array}{l}\text { High risk of change in } \\
\text { neighbourhood } \\
\text { character in future by } \\
\text { transforming laneway to } \\
\text { street }\end{array}$ & $\begin{array}{l}\text { Pressuring } \\
\text { infrastructure } \\
\text { by the } \\
\text { addition of } \\
\text { high density }\end{array}$ & $\begin{array}{l}\text { High risk of shadowing } \\
\text { and privacy issues due } \\
\text { to the addition of } \\
\text { high density and } \\
\text { creating compact } \\
\text { fabric }\end{array}$ \\
\hline A-1 & & & 191 & 34.7 & -110 & -20 & & & & & \\
\hline A-2 & & & 301 & 54.7 & 0 & 0 & & & & & \\
\hline$A-3$ & & & 191 & 34.7 & -110 & -20 & & & & & \\
\hline B-1 & & & 383 & 69.6 & 82 & 14.9 & & & & & \\
\hline B-2 & & & 430 & 78.2 & 129 & 23.5 & & & & & \\
\hline C-1-1 & & & 337 & 61.3 & 36 & 6.5 & & & & & \\
\hline$C-1-2$ & & & 337 & 61.3 & 36 & 6.5 & & & & & \\
\hline C-2-1 & & & 362 & 65.8 & 61 & 11.1 & & & & & \\
\hline$C-2-2$ & & & 362 & 65.8 & 61 & 11.1 & & & & & \\
\hline C-3 & & & 603 & 109.6 & 302 & 54.9 & & & & & \\
\hline D-1 & & & 1452 & 264 & 1151 & 209.3 & $\begin{array}{l}\text { It was anticipated that it would } \\
\text { change the character, it did } \\
\text { not change. }\end{array}$ & & & & \\
\hline D-2 & & & 1152 & 209.4 & 851 & 154.3 & & & & & \\
\hline
\end{tabular}

Table 9: Summary of the results of the developed scenarios

62 


\section{7- Discussion and Recommendations}

This research was initially designed to investigate the opportunities for increasing density to address issues of income polarization in Toronto. In the course of the research it was revealed that informal housing can be and is currently a source of affordable housing in stable neighbourhoods near transit. Additionally, the spatial analysis of the middle and low income areas of the city highlighted a large portion of these areas have laneways, and have the potential for additional density in laneways. This section discusses the results of this research:

\section{Informal housing, affordability and morphology}

Informal housing is a phenomenon outside of conventional planning process and typically indicates a need for increased affordable housing. Housing informality is a way to leverage affordability from individual home owners by generating income for homeowners and providing low cost housing choice. Therefore housing informality can increase ownership and rental housing affordability. It can be argued that informal housing in Toronto is a spontaneous activity fulfilling the unmet need of affordable housing. Based on the results of field observation in the Palmerston neighbourhood of Toronto, it appears that a large number of housing units in the area are practicing informal means they do not compile with urban regulations and do not recognized legal by the City of Toronto and Toronto Hydro. The area is a desired place to live due to the location of the study area in proximity to transit networks, to the Downtown, to Ryerson University and to the University of Toronto. At the same time the cost of housing is increasing making the area less affordable to live in. Informal housing in this situation appears to have created an opportunity for middle and low income individuals to stay in the neighbourhood by using rental from affordable units to fund the purchase of the house for the middle income and provide a place to live for the low income, because informal units are usually cheaper than comparable legal units.

Depending on the type of informality, some types of informal housing can impact the morphology of a neighbourhood while some other are unlikely change urban fabric as they are 'hidden' within the dwelling. From the view point of morphology informal housing can be categorized in two groups:

1- Those informal units that impact urban fabric in a minor way as they are located within a legal structure and physically hidden. For example if a triplex building has seven ring bells and mailboxes while having only three hydro meters, it appears to indicate there are four informal units within the legal triplex structure. These extra four units can have negligible impact on morphology.

2- Those informal units change urban fabric in a major way due to the fact that these units are physical structures added to existing legal buildings. For instance a suite located above a garage is an informal unit that is evident since it adds to the legal height of the garage. 


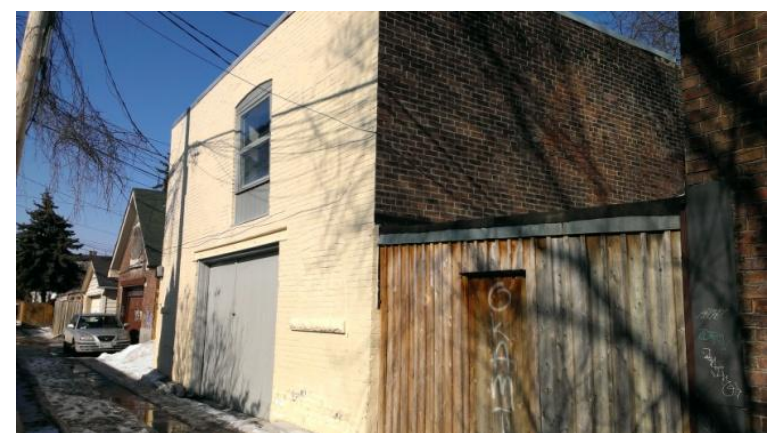

Figure 98: A suite located above a garage, noticed informality in the study area (Image by author, 2014)

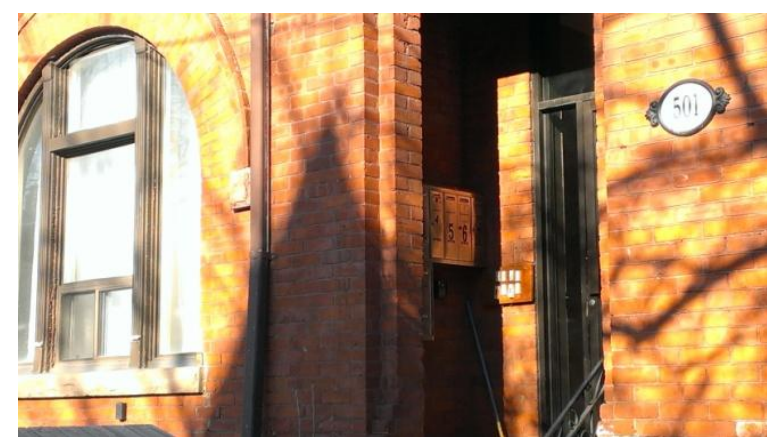

Figure 99: Multiple mail boxes and ring bells, noticed informality in the study area (Image by author, 2014)

Field observation in the study area in the Palmerston neighbourhood in Toronto illustrates that the main type of noticed informality is located within the existing buildings and does not manifest evident physical in changing the morphology. A few suites above garages located in the laneways are the only visible informal units in the area that only change the physical character of the neighbourhood in a minor way as illustrated in Scenario A2. An increase of this phenomenon is illustrated in Scenario B-1 and B-2.

Overall, informal housing provides affordable housing for middle and low income individuals in stable neighbourhoods while it changes the physical character of a neighbourhood in a minor way. As informal housing can be a valuable source of affordable housing for accommodating low and middle income earners in stable neighbourhoods and in proximity to transit networks and also as informal housing have small impact on urban fabric, this study recommends the following topics for future research about housing informality in Toronto: the challenges and disadvantages of informal housing, the reaction of the City of Toronto to informal housing, and the impact of the City's reaction on the affordability of informal units.

\section{Opportunities for the addition of affordable density}

Given that middle and low income individuals are being pushed out from areas in the core of the city and gradually have less access to transit networks, this study investigates opportunities for increasing affordable housing choices in walkable areas of Toronto. Based on the result of spatial analysis of middle and low income neighbourhoods in proximity to transit networks and laneway structures, $13.2 \%$ of the properties in these areas have access to laneways indicating a great spatial potential for increasing density in walkable low and middle income areas by laneway developments.

Prior to any policy implications for laneway housing, it is necessary to conduct in depth research on different aspects of laneway developments such as servicing and privacy issues. Currently the City is reluctant to approving laneway developments mainly due to the privacy and servicing issues. This study recommends the City to conduct an in depth research on laneway developments and also to look at Vancouver model and its potential 
for adaption in Toronto given the potential benefits of laneway structure in Toronto for increasing affordable density and addressing the problem of income polarization.

Considering the existing as-of-right and the existing physical character of Toronto neighbourhoods, there is an opportunity for increasing density designations of Toronto's Zoning By-law. The study of the morphology of the area indicated the actual density is approximately 2.5 times higher than the current density designations of 0.6 defined by the Toronto's Zoning By-law. The difference between the allowed density and the actual density in the area highlights the opportunity for increasing density limit of the Zoning By-law to 1.5. Increasing zoning limit to 1.5 will maintain the physical character of the area, as density of 1.5 is the density of the existing physical character of the area. For example a property with an area of 100 square metres, the allowable density is 60 square metres (0.6x100). Considering the minimum dwelling unit area 25 square metres, 60 square metres can accommodate 2.4 units and the additional density can increase housing choice.

This study presents that how high we can built in stable neighbourhoods while maintaining neighbourhood character. It is important to recognize this study does not aim for a definitive answer, but to illustrate the possibilities for increasing affordable density in stable neighbourhoods. This study demonstrated the spatial capacity of Toronto for accommodating more small scale density and also for laneway developments; it has some limitations and shortcomings. This research highlights that morphology and spatial capacity of an area plays a major role for making any decision about increasing density. However, there are other factors need to be considered for increasing density, such as infrastructure capacity and privacy.

\section{A new character within the existing character}

As illustrated in the result section, Scenario $D$ has major impact on the morphology of the area in terms of increasing massing and height. However, these developments will not be visible from street, indicating that they will not change the street character. It can be argued that these developments have the potential to create a new character for neighbourhood while retaining its original physical character. This study utilizes the study of Allan B. Jacobs on "Great Streets" (1993) to imagine how the new character will look like. The ratio between height of laneway houses and laneway width in scenario $\mathrm{D}$ was determined and based on the calculated ratio a comparable street from "Great Streets" has been found.

Via dei Coronari and Via Giulia are two historic streets in Rome, Italy have a similar proportion of width and height as the laneways in Scenario D. European streets are beloved for being pedestrian-friendly. Narrow streets with relatively tall buildings, like Via dei Coronari and Via Giulia, can be great streets as they have a sense of 'mystery' that is inviting to be explored. In addition, the narrowness of streets and height of buildings protect pedestrians from wind. Via dei Coronari and Via Giulia streets highlight that Scenario D has the potential to create a very interesting urban space. 

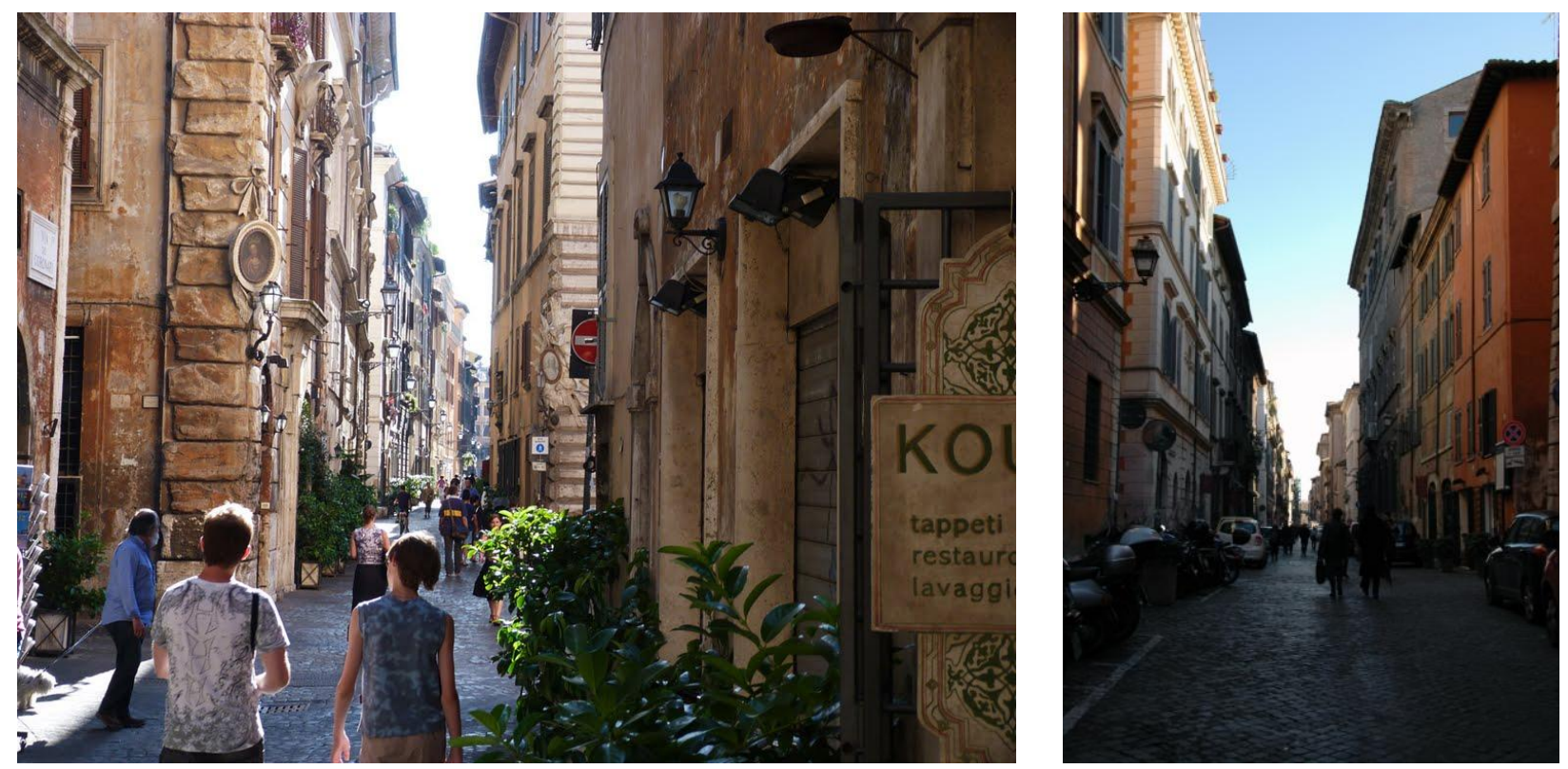

Figure 100 and 101: Via dei Coronari (left) and Via Giulia (right) in Rome, Italy illustrating two great streets with a similar proportion of width and height to scenario D. (Images retrieved from: http://www.panoramio.com/photo/57214496 and from www.go-today.com/blog/travel-explorations/8-unforgettable-experiences-in-rome-italy/attachment/via-giulia-rome/

\section{8- Conclusion:}

Utilizing Hulchanski's research, this paper has addressed the need for affordable housing unit in middle and low income areas near to public transit and services through laneway housing and informal housing. The impact of increasing density on the physical character of neighbourhoods was highlighted as the main determinant in exploring and evaluating intensification choices. This study has presented that even 6-storey laneway developments can maintain neighbourhood character. Also the potential for the creation of a new character, similar to the character of historic European streets, is identified while retaining the original character of neighbourhoods. This study has indicated that there is a major potential for increasing density through laneway development. It is revealed that about $13 \%$ of those areas of the city that is close to transit and located in the middle and low income areas of the city have access to laneways. This highlights a potential for increasing density through laneway development.

Additionally, it was argued that informal housing is a viable source of affordable housing in stable neighbourhoods of Toronto. Overall, this study has argued that laneway housing and informal housing have the potential for increasing affordable density for low and middle income earners in areas in proximity to transit while maintaining the integrity of neighbourhood character. As one of the major barriers for laneway developments in Toronto is privacy issues (Planner A and C, 2014), it is important for future research to more thoroughly investigate how privacy issues associated with laneway developments can be addressed. Also it is recommended to study potential solutions for providing services for laneway houses, such as fire access and winter maintenance and to investigate the impact of laneway developments on the city's infrastructure. 


\section{RYERSONUNIVERSITY}

\section{RESEARCH ETHICS BOARD}

\section{To: Samira Behrooz \\ School of Urban and Regional Planning}

Re: REB 2013-323: Informal housing in Toronto and its morphological impact

Date: January 10, 2014

\section{Dear Samira Behrooz,}

The review of your protocol REB File REB 2013-323 is now complete. The project has been approved for a one year period. Please note that before proceeding with your project, compliance with other required University approvals/certifications, institutional requirements, or governmental authorizations may be required.

This approval may be extended after one year upon request. Please be advised that if the project is not renewed, approval will expire and no more research involving humans may take place. If this is a funded project, access to research funds may also be affected.

Please note that REB approval policies require that you adhere strictly to the protocol as last reviewed by the REB and that any modifications must be approved by the Board before they can be implemented. Adverse or unexpected events must be reported to the REB as soon as possible with an indication from the Principal Investigator as to how, in the view of the Principal Investigator, these events affect the continuation of the protocol.

Finally, if research subjects are in the care of a health facility, at a school, or other institution or community organization, it is the responsibility of the Principal Investigator to ensure that the ethical guidelines and approvals of those facilities or institutions are obtained and filed with the REB prior to the initiation of any research.

Please quote your REB file number (REB 2013-323) on future correspondence.

Congratulations and best of luck in conducting your research.

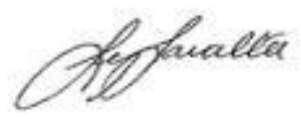

Lynn Lavallée, Ph.D.

Chair, Research Ethics Board 


\section{Appendix B: Interview Guide and Consent Form}

\section{RYERSON \\ UNIVERSITY}

\section{Everyone Makes a Mark}

\section{Interview Guide}

Title of study: Informal housing in Toronto and its morphological impact Researcher: Samira Behrooz

This interview guide is directed for interviews with professionals and researchers in planning and architecture. This study has been approved by the Ryerson University Research Ethics Board.

\section{Introduction:}

1. Personal Introduction

2. Introduction of the research project and the research objectives

3. Inform participants of their rights

4. Signature of participant's consent form

\section{Categories and Topics of Interest:}

1. Informal housing in Toronto: key drivers, benefits and problems for both the middle income class and the City of Toronto.

2. Alternatives to informal housing to increase affordability in the inner city.

3. Laneway housing in Toronto: the opportunities and challenges for both the middle income class and the City of Toronto.

\section{Question Guide:}

1. Describe some of your current work experience.

2. Describe some of your experience with informal housing.

3. What are your thoughts about the key drivers of informal housing in the City of Toronto?

4. In your opinion, how can informality be beneficial in increasing housing affordability?

5. In your experience, do you think informal housing would be beneficial to the City of Toronto in increasing density in the inner city?

6. In your opinion, how has the City of Toronto reacted to informal housing? 
7. What do you think some alternatives to informal housing are that can increase affordability in the inner city?

8. Describe your opinion about laneway housing. Can you elaborate on how it can be beneficial in increasing affordability and also density in the City of Toronto?

9. Is there anything you would like to add or any questions that I haven't asked you about that I should have?

\section{Concluding Remarks:}

1. Thank participants.

2. Allow time of post-interview discussion. 


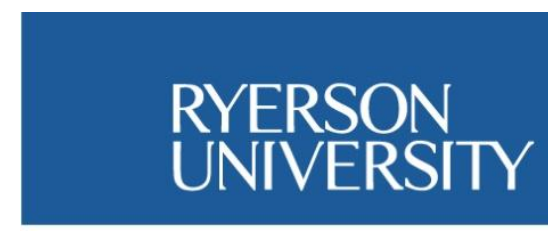

\section{Everyone Makes a Mark}

\section{Consent to participate in research}

\section{Title of study: "Informal housing in Toronto and its morphological impact"}

You are being invited to participate in a research study. The study has been approved by the Ryerson University Research Ethics Board. Please read this Consent Form so that you understand what your participation will involve. Before you consent to participate, please ask any questions necessary to be sure you understand what your participation will involve.

\section{Investigators}

This research study is being conducted by Samira Behrooz, a graduate student from the School of Urban and Regional Planning at Ryerson University. Results will contribute to a major research project.

If you have any questions or concerns about the research, please feel free to contact:

Dr. Shelagh McCartney, the faculty supervisor

Email: shelagh.mccartney@ryerson.ca

Phone: 416-979-5000 x2133

Samira Behrooz, the research investigator

School of Urban and Regional Planning, Ryerson University

Email: samira.behrooz@ryerson.ca

\section{Purpose of the study}

The purpose of this research project is to investigate how informal housing (housing units that do not comply with urban regulations) in Toronto could increase affordability in the inner city and how such practices influence built environment. This project will focus on a neighborhood [TBD] in the City of Toronto as a case study.

\section{Description of the study and your participation}

- The research will be conducted through semi-structured interviews with key members of Toronto's community with knowledge and experience about informal housing. The semi-structured interviews are individual interviews. 
- It is estimated that interviews will be conducted between January and March 2014.

- Interviews will be scheduled at your convenience, either in your public office, a private meeting room in a public space or a reserved room at Ryerson. Interviews will be done during the daytime.

- It is expected to conduct only one interview; however, follow-ups may be needed for clarification. If so, you will be contacted by email. There may be only one follow-up interview which would occur in February or March 2014. Types of questions for a possible follow-up interview would be the same as the original questions of the first interview.

If you volunteer to participate in this study, you will be asked to do the following things:

- You will be asked to read and sign the Consent Form.

- Your name and job title will be collected.

- You will be asked questions about:

- Informal housing in Toronto: key drivers, benefits and problems for the middle income class and for the City of Toronto;

- Alternatives to informal housing to increase affordability in the inner city;

- Laneway housing in Toronto: opportunities and challenges for the middle income class and for the City of Toronto.

- Sample questions:

- What are your thoughts about the key drivers of informal housing in the City of Toronto?

- In your opinion, how can informality be beneficial in increasing housing affordability?

- What do you think some alternatives to informal housing are that can increase affordability in the inner city?

- You will be provided with investigator's contact information, which you can use to contact investigator at any point if you would like to see the research results. These results will be available by May 2014.

\section{Potential risks and discomforts}

You have the right to:

- Decline the interview.

- Refuse to answer questions for any reason.

- Stop participating at any time.

You should be informed that:

- There are no major perceived risks from participating in this interview. Potential risks are very low. There may be possibilities of inconvenience to your personal time and schedule.

- There may be a limit to confidentiality. While every effort will be made to protect the confidentiality of participants, the small size of the intended sample and the possibly specific and/or expert nature of information given by participants and reflected in unattributed quotes used in the resulting manuscript may render participants identifiable.

\section{Potential benefits to participants and/or to society}

You may not experience any direct benefits from participation in this study. It is hoped that the study will add to the body of knowledge about informal housing and will contribute to the discussions about affordable housing. 


\section{Payment for participation}

You will not be paid to participate in this study.

\section{Confidentiality}

- Participants will not be video recorded or photographed. Your comments will be audio recorded and written during the interview. You will have the right to review the recordings/transcripts. Electronic data (including digital audio recordings) will be encrypted, stored on the research investigator's password protected personal computer and will be backed-up on a password protected external hard-drive. Hardcopy information will be stored in a locked cabinet at Ryerson. Any documents with identifying information will be stored separately from audio recordings and written interview notes. The investigator, Samira Behrooz, will be the only individual who has access to all data during the research project. Data will be permanently destroyed in May 1, 2017. Please be aware that some of your comments will be presented as part of research findings. These comments will be shared with the faculty and students of the School of Urban and Regional Planning at Ryerson University, since it is a public work.

- Participant name and identifying characteristics will not be used within the research data and any publications.

\section{Voluntary participation and withdrawal}

Participation in this study is voluntary. You can choose whether to be in this study or not. If you volunteer to be in this study, you may withdraw at any time without consequences of any kind. If you choose to withdraw from this study you may also choose to withdraw your data from the study. You may also choose not to answer any question(s) and still remain in the study. Your choice of whether or not to participate will not influence your future relations with Ryerson University.

\section{Questions about the study}

If you have any questions about the research now, please ask. If you have questions later about the research, you may contact the research investigator at samira.behrooz@ryerson.ca.

This study has been reviewed by the Ryerson University Research Ethics Board. If you have questions regarding your rights as a research participant in this study, please contact:

Toni Fletcher, Research Ethics Coordinator

Research Ethics Board

Office of the Vice President, Research and Innovation

Ryerson University

350 Victoria Street

Toronto, Ontario M5B 2K3

416-979-5042 or toni.fletcher@ryerson.ca 


\section{Signature of research participant}

Your signature below indicates that you have read the information in this agreement and have had a chance to ask any questions you have about the study "Informal housing in Toronto and its morphological impact" as described herein. Your questions have been answered to your satisfaction, and you agree to participate in this study. You have been given a copy of this form.

Name of Participant (please print)

Signature of Participant

Date

Your signature below indicates that you agree to be audio recorded during the interview.

Name of Participant (please print)

Signature of Participant

Date 


\section{Bibliography:}

AlSayyad, N. (2004). "Urban Informality as a 'New' Way of Life." In Urban Informality: Transnational Perspectives from the Middle East, Latin America, and South Asia, edited by Ananya Roy and Nezar AlSayyad. Lexington Books.

Andrews, J. H. (2005). Not your grandmother's granny flat. Planning, 71(3), 8-9.

Aravena, A. (2012). Elemental : incremental housing and participatory design manual. Ostfildern. Hatje Cantz.

Baird, G. and Myers, B. (1978). Vacant Lottery. Design Quartely No. 108. Walker Art Centre. Minneapolis.

Blackie, N.K. (1986). The option of staying put. In G.M. Gutman (Ed.), Aging in place: Housing adaptations and options for remaining in the community. Burnaby: The Gerontology Research Centre.

Calabrese, R. L. (2006). The elements of an effective dissertation and thesis: A step-by-step guide to getting it right the first time. Lanham, Md: Rowman \& Littlefield Education.

Campoli, J., \& MacLean, A. S. (2007). Visualizing density. Cambridge, Mass: Lincoln Institute of Land Policy.

Canada Mortgage and Housing Corporation (2012). Rental Market Report - Greater Toronto Area. Retrieved from http://www.cmhc-schl.gc.ca/odpub/esub/64459/64459_2012_A01.pdf

Cavallaro, M. (1998). A study of infill housing development in the old city of Toronto's west end. Thesis--Ryerson Polytechnic University.

City of Toronto, City Planning Division (2013). Housing Potential Analysis. Retrieved from http://www.toronto.ca/legdocs/mmis/2013/pg/bgrd/backgroundfile-63572.pdf

City of Toronto. (2010). Toronto Official Plan. Retrieved from http://www1.toronto.ca/static_files/CityPlanning/PDF/chapters1_5_dec2010.pdf

City of Toronto (2003). Toronto Urban Design Guidelines - Infill Townhomes. Toronto: City of Toronto Urban Development Services.

City of Toronto. (2013). Zoning By-law 569-2013. Retrieved from http://www1.toronto.ca/wps/portal/contentonly?vgnextoid=2a8a036318061410VgnVCM10000071d60f8 9RCRD

City of Vancouver. (2013). Laneway Housing How-to Guide. Retrieved from: http://vancouver.ca/files/cov/laneway-housing-howto-guide.pdf

Crowther, W.G. and City of Toronto. (2006). Staff report: Construction of Housing in Laneways. Retrieved from: http://www.toronto.ca/legdocs/2006/agendas/committees/wks/wks060705/it007b.pdf

Cubitt, E.L. (2008). Laneway Infill: Re-Creating an Urban Housing Typology. University of Waterloo. School of Architecture masters thesis.

Dault, G. M. (2004). Inverse city. The Canadian Architect. 49(10). 
Dobson, C. (2008). Backyard and On-Street Infill Housing. Alternatives Journal. 34.3 : 29.

Geary, V., Eberle, M. P., and Kraus, D. (1999). The impact of secondary suites on municipal infrastructure and services. Ottawa: Canada Mortgage and Housing Corporation.

Getzel, P. M. (1999). Developing Infill Housing in Inner-City Neighborhoods: Opportunities and Strategies. Journal of the American Planning Association. $65.4: 441$.

Gratton, M. C. (2011). An Analysis of Secondary Suites as a Policy Instrument in the City of Edmonton. University of Manitoba. City planning masters thesis.

Harris, R. (1996). Unplanned suburbs : Toronto's American tragedy, 1900 to 1950. Johns Hopkins University Press. Baltimore.

Haughey, R. and others. (2001). Urban infill housing : myth and fact. Washington, D.C. : Urban Land Institute

Hulchanski, D. (2010). The three cities within Toronto. University of Toronto. Final edition. Toronto. Canada.

Howe, D. (1990). The flexible house: Designing for changing needs. Journal of the American Planning Association, 56(1), 69-77.

Jackson, E. (2012). Vancouver's middle class shrinks, poverty spreads along SkyTrain.

Jacobs, A. B. (1993). Great streets. Cambridge, Mass: MIT Press.

Janzen, Kristine. (Feb 8, 2012). REGULATING SECOND SUITES. Novae Res Urbis : Greater Toronto Area Edition. 15.6: 1,4. Toronto: NRU Publishing Inc.

Kapusta, B. (2005). Urban tree house. The Canadian Architect. 50(6): 24.

Karakas, J. (2009). Livable Lanes: A Study of Laneway Infill Housing in Vancouver and Other Growing B.C. Communities. Canada Mortgage and Housing Corporation: Ottawa, Ontario. Retrieved from: www.cmhcschl.gc.ca/odpub/pdf/66642.pdf

Kinnis, R. (1995). Zoning and innovative, affordable infill housing : Sevag Pogharian Design, Montreal : affordability and choice today (A.C.T.) : a case study / prepared for Federation of Canadian Municipalities. Ottawa : Canada Builders' Association

Ley, David and Lynch Nicholas. (October 2012). Divisions and Disparities in Lotus-Land: Socio-Spatial Income Polarization in Greater Vancouver, 1970-2005. Toronto, Canada: Cities Centre Press, University of Toronto, pp.16-17.

Martin, M. D. (2002). The case for residential back alleys: A North American perspective. Journal of Housing and the Built Environment. 17: 145-171.

Mendez, P. (2011). Ambiguity at Home: Unauthorized Geographies of Housing in Vancouver. University of British Columbia. PhD dissertation.

Neuman, W. L. (2010). Social research methods: Qualitative and quantitative approaches. Boston, Mass: Allyn and Bacon. 
Robinson, K. (2013). Towards Inclusive Affordable Housing: Toronto's Large Sites Policy- Just a Formality? Carlton University. School of Architecture masters thesis.

Ruud, M. E., and V. Nordvik. (1999). "From the Kitchen Floor to the Basement-Sharing Arrangements in Two Centuries." Housing, Theory and Society 16 (4): 192-200.

Shenback, B. (2009). Infill housing design guidelines in mature urban neighbourhoods: Recommendations for Winnipeg. University of Manitoba. City planning masters thesis.

Shim, B., Chong, D., Waldheim, C., Adams, S., \& University of Toronto (2004). Site unseen: Laneway architecture \& urbanism in Toronto. Toronto, Ont.: University of Toronto Faculty of Architecture, Landscape, and Design.

Smith-Hamilton, J. (2006). In My Back Yard: A Back Lane Approach to Zoning and Density. University of British Columbia School of Architecture masters thesis.

Soules, M. (2011). Back to Front. The Canadian Architect. 56(11).

Steinacker, A. (March 2003). Infill Development And Affordable Housing: Patterns from 1996 to 2000. Urban Affairs Review. 38 (4), pg. 492-509

Stinson, J. and Van E.T. (2003). A Study in Laneway Housing in Toronto. Canada Mortgage and Housing Corporation: Ottawa, Ontario.

Sewell, J. (1993). The shape of the city: Toronto struggles with modern planning. Toronto: University of Toronto Press.

The Starr Group (2000). Secondary Rental Market Study: final report. The Ontario Ministry of Municipal Affairs and Housing, and Canada Mortgage and Housing Corp. Toronto. Canada.

Toronto laneway renaissance. (2013). Retrieved from http://lanewayrenaissance.com/

Toronto Municipal Code - Chapter 629 Property Standards. (2013). Retrieved from http://www.toronto.ca/legdocs/municode/1184_629.pdf

Tyndorf, T. (2006). Perspectives on Affordable Housing. Toronto, Canada: Toronto City Planning, pp.1-30.

Wegmann, J. (2014). "We Just Built It:" Code Enforcement, Local Politics, and the Informal Housing Market in Southeast Los Angeles County. University of California: Berkley. PhD dissertation (Draft copy).

Zelinka, A. and Beattie, W. (2003). How to turn alleys into allies. Planning 69(10): 25. 